Supporting Materials for

\title{
Phospholane-Based Ligands for Chromium-Catalyzed Ethylene Tri- and Tetramerization
}

Scott D. Boelter, Dan R. Davies, Peter Margl, Kara A. Milbrandt, Darrek Mort, Britt A. Vanchura II, David R. Wilson, Molly Wiltzius, Mari S. Rosen* and Jerzy Klosin*

Corporate R\&D, The Dow Chemical Company, 1776 Building, Midland, MI 48667

*Corresponding authors, e-mail: msrosen@dow.com (MSR), jklosin@ dow.com (JK) 


\section{TABLE OF CONTENTS}

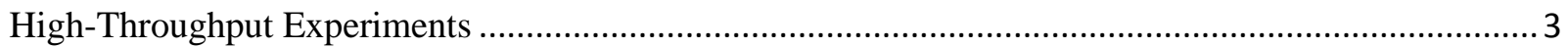

Analytical Procedures for Analyzing Products from Ethylene Oligomerization Experiments................. 4

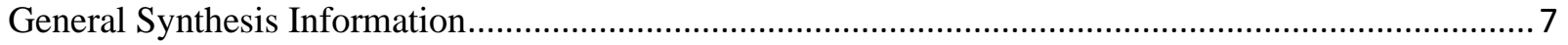

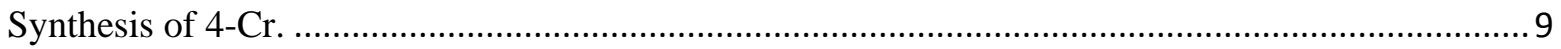

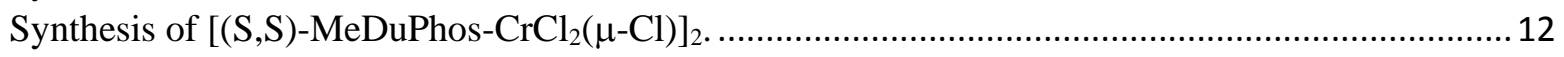

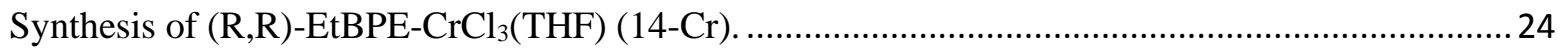

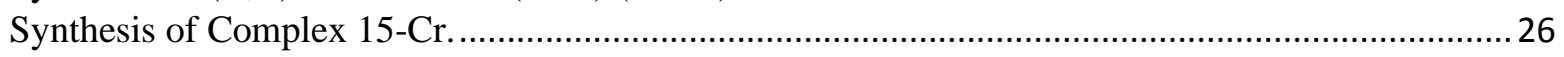

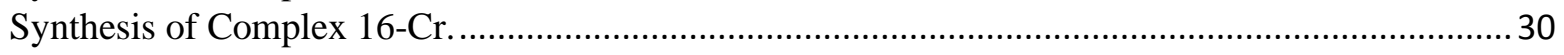

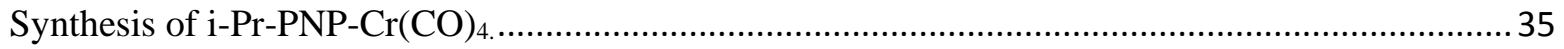

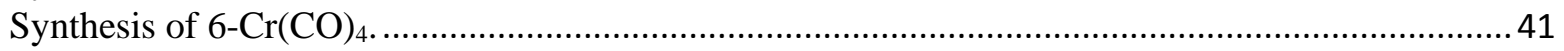

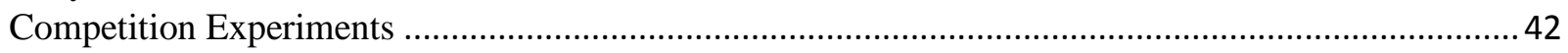

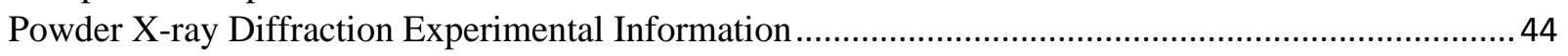

Powder X-ray Diffraction Experimental Description ............................................................... 44

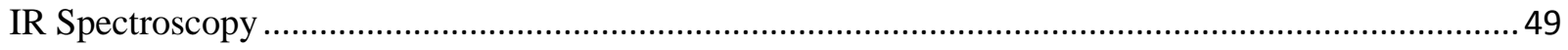

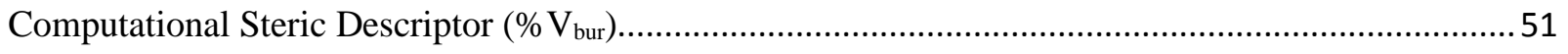

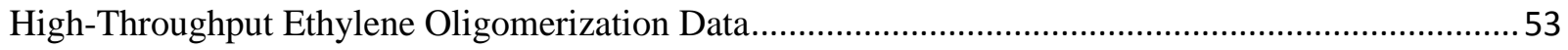

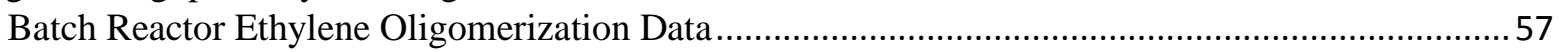

Example of Activity and Selectivity Calculations: $10-\mathrm{Cr}$............................................................ 59

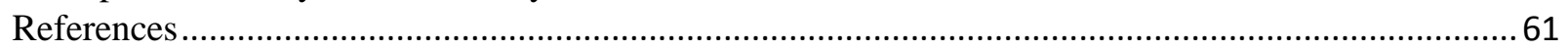




\section{High-Throughput Experiments}

All catalytic evaluations were performed using a high-throughput reactor housed in a nitrogenfilled glovebox in which reactions are performed in 24 individual reactor cells in a stainless-steel block fitted with glass inserts. All 24 reactors share a common headspace. Efficient mixing is achieved through the use of magnetic stir bars. The ethylene feed and the methylcyclohexane solvent were passed through purification columns containing A2 alumina (activated under nitrogen for 8 hours at $300{ }^{\circ} \mathrm{C}$ ) and Q5 reactant $\left(\mathrm{Q} 5\right.$ reactant activated under $5 \% \mathrm{H}_{2}$ in argon for one hour and then under nitrogen for seven hours at $200{ }^{\circ} \mathrm{C}$ ). Chlorobenzene and nonane were purified by passing them through activated alumina. The methylcyclohexane, chlorobenzene, and nonane were stored over activated $3 \AA$ molecular sieves $(3 \AA$ molecular sieves are activated under nitrogen for four hours at $250{ }^{\circ} \mathrm{C}$ ).

Precatalyst solutions for in situ metallations were prepared in $8-\mathrm{mL}$ vials by mixing the ligand and $\mathrm{CrCl}_{3}(\mathrm{THF})_{3}$ in situ in chlorobenzene as follows: $150 \mu \mathrm{L}$ of $1.0 \mathrm{mM}$ solution of $\mathrm{CrCl}_{3}(\mathrm{THF})_{3}$ in chlorobenzene was combined with $180 \mu \mathrm{L}$ of $1.0 \mathrm{mM}$ solution of the ligand in chlorobenzene in a 1:1.2 ratio in 8-mL vials. The samples were mixed for 30 minutes on a shaker prior to addition to the glass inserts. For preformed complexes, precatalyst solutions comprised $1 \mathrm{mM}$ solutions of the metal complexes in chlorobenzene.

Each glass insert was equipped with a magnetic stir bar, weighed, and charged with a predetermined amount of methylcyclohexane solvent via a liquid handler such that the final volume would be $4 \mathrm{~mL}$. The liquid handler then delivered a solution of $10 \mathrm{wt} \%$ nonane (the GC internal standard in methylcyclohexane) for a total of $50 \mathrm{mg}$ nonane in each glass insert. 52.6 $\mu \mathrm{L}$ of an MMAO-3A solution (1.9 $\mathrm{M}$ in methylcyclohexane, $100 \mu \mathrm{mol}$ final loading), followed by $220 \mu \mathrm{L}$ of in situ precatalyst solution $(0.1 \mu \mathrm{mol}$ $\mathrm{Cr}$ final loading) or $100 \mu \mathrm{L}$ of preformed complex precatalyst solution $(0.1 \mu \mathrm{mol} \mathrm{Cr}$ final loading), were then added to the glass inserts via an Eppendorf pipette. The glass tubes were inserted into the reactor that was subsequently sealed. The cells were pressurized with $100 \mathrm{psi}$ of ethylene and heated to $60{ }^{\circ} \mathrm{C}$, as monitored by five thermocouples in the stainless-steel block. Once the reaction temperature was reached, the cells were pressurized up to 500 psi with ethylene.

A duplicate of each experiment was performed in each high-throughput run. Furthermore, $i$-Pr-PNP (1) was included in each library as a positive control. Consistent activity and selectivity of this standard from run to run allowed for the catalysis results to be compared across high-throughput runs.

After 30 minutes, the reactions were terminated by stopping the ethylene feed and cooling to room temperature. The reactor was slowly vented at room temperature in order to limit loss of low-boiling analytes such as 1-hexene. A liquid sample was removed from each reaction for GC analysis, and the 
remainder of the liquid present was removed in vacuo on a Savant SC250EX SpeedVac Concentrator (Thermo Fisher). The glass tubes were then weighed to determine the amount of solids present. The weight of the residual solids from the tube containing only MMAO-3A solution was subtracted from the weight of the total residual solids in each reaction vial to yield the amount of polymer produced in each reaction.

\section{Analytical Procedures for Analyzing Products from Ethylene Oligomerization Experiments.}

The liquid reaction products were analyzed on an Agilent 7890 GC System. The GC conditions for the 7890 system are given in Table S1.

Table S1. GC conditions

\begin{tabular}{|c|c|}
\hline GC & Agilent 7890 Series \\
\hline Column & Agilent (DB-5MS), $30 \mathrm{~m} \times 32 \mu \mathrm{m}, 1 \mu \mathrm{m}$ film \\
\hline Oven & $\begin{array}{l}70{ }^{\circ} \mathrm{C} \text { for } 8 \mathrm{~min} \text {, ramp } 50{ }^{\circ} \mathrm{C} / \mathrm{min} \text { to } 300{ }^{\circ} \mathrm{C} \text { (hold } 3.4 \mathrm{~min} \text { ) Total time- } 16 \\
\min \end{array}$ \\
\hline Inlet & $300{ }^{\circ} \mathrm{C}$, Split, 30:1 split ratio \\
\hline Carrier Gas & Hydrogen, $1.33 \mathrm{~mL} / \mathrm{min}$ constant flow \\
\hline $\begin{array}{ll}\text { Flame } & \text { Ionization } \\
\text { Detector } & \end{array}$ & $320^{\circ} \mathrm{C}, 45 \mathrm{~mL} / \mathrm{min} \mathrm{H}_{2}, 450 \mathrm{~mL} / \mathrm{min}$ air \\
\hline Injection Volume & $1 \mu \mathrm{L}$, chlorobenzene wash solvent \\
\hline
\end{tabular}

Samples for GC analysis were prepared by quenching $75 \mu \mathrm{L}$ of the reaction mixture with $25 \mu \mathrm{L}$ of methanol. The response factors were determined for 1-octene, 1-hexene, methylcyclopentane, and methylenecyclopentane via calibration using a standard solution with known concentrations. The response factors used for the $\mathrm{C} 10$ to $\mathrm{C} 18$ fractions were determined using the terminal olefin of the same carbon length (e.g., 1-decene for the $\mathrm{C} 10$ fraction). The concentrations of the reaction products were reported by the $\mathrm{GC}$ on a $\mathrm{g} / \mathrm{g}$ nonane basis because nonane was included as an internal standard at a known concentration in the reaction tubes $(50 \mathrm{mg}$ of nonane per $5 \mathrm{~mL}$ of reaction mixture). The amounts of the various reaction products produced were calculated relative to the amount of nonane added to the reaction mixture.

Table S2. Retention times for C10-C18 products

\begin{tabular}{|c|c|}
\hline Product & Retention time $(\mathrm{min})$ \\
\hline Decenes & $10.00-11.00$ \\
\hline Dodecenes & $11.30-11.80$ \\
\hline Tetradecenes & $11.81-12.70$ \\
\hline Hexadecenes & $13.00-13.50$ \\
\hline Octadecenes & $13.70-14.20$ \\
\hline
\end{tabular}


Figure S1. Example GC Chromatograms for $\mathbf{1}+\mathbf{C r C l}_{\mathbf{3}}(\mathbf{T H F})_{3}$.
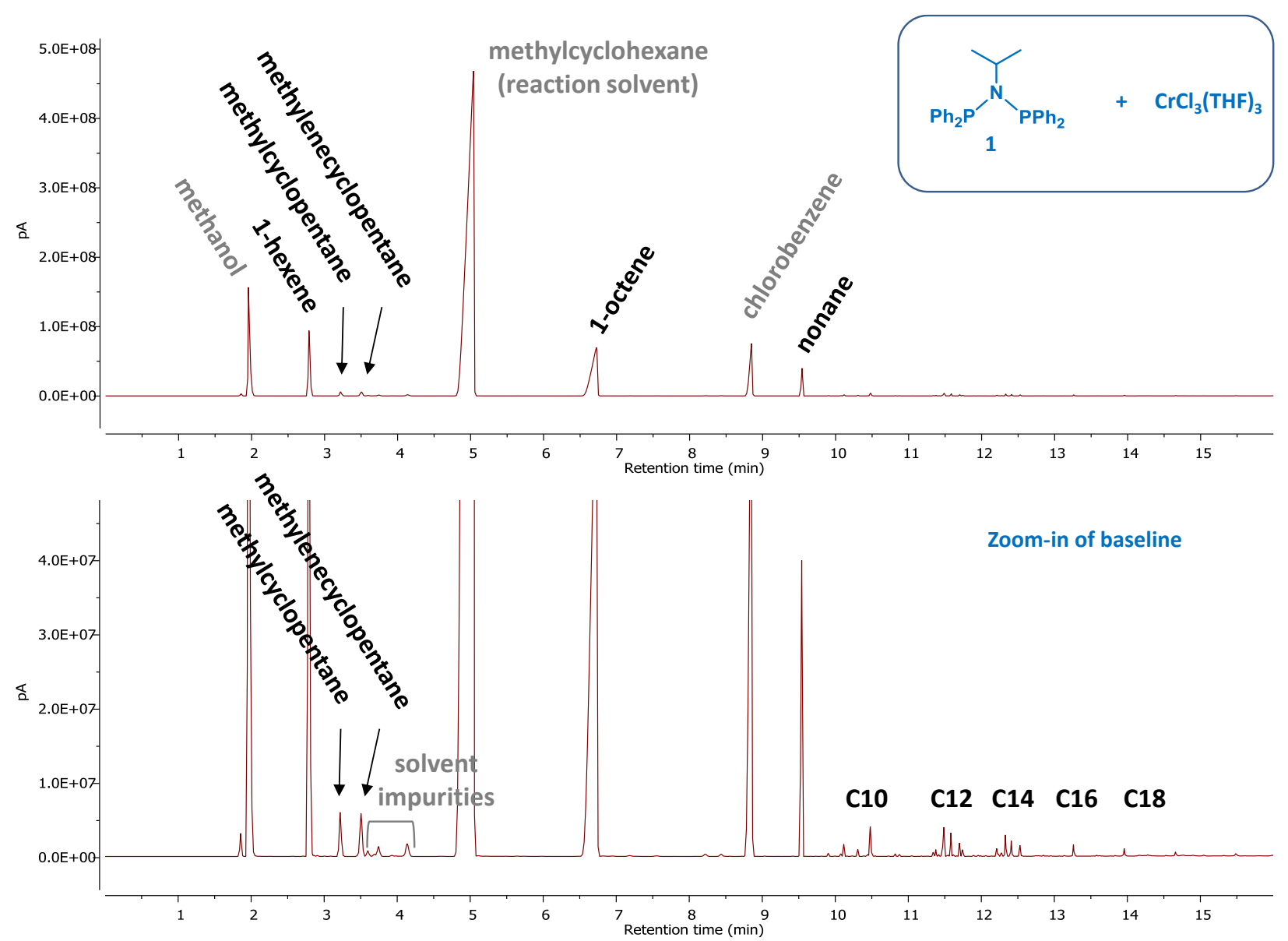
Figure S2. Example GC Chromatograms for $\mathbf{1 0}+\mathbf{C r C l}_{\mathbf{3}}(\mathbf{T H F})_{3}$.

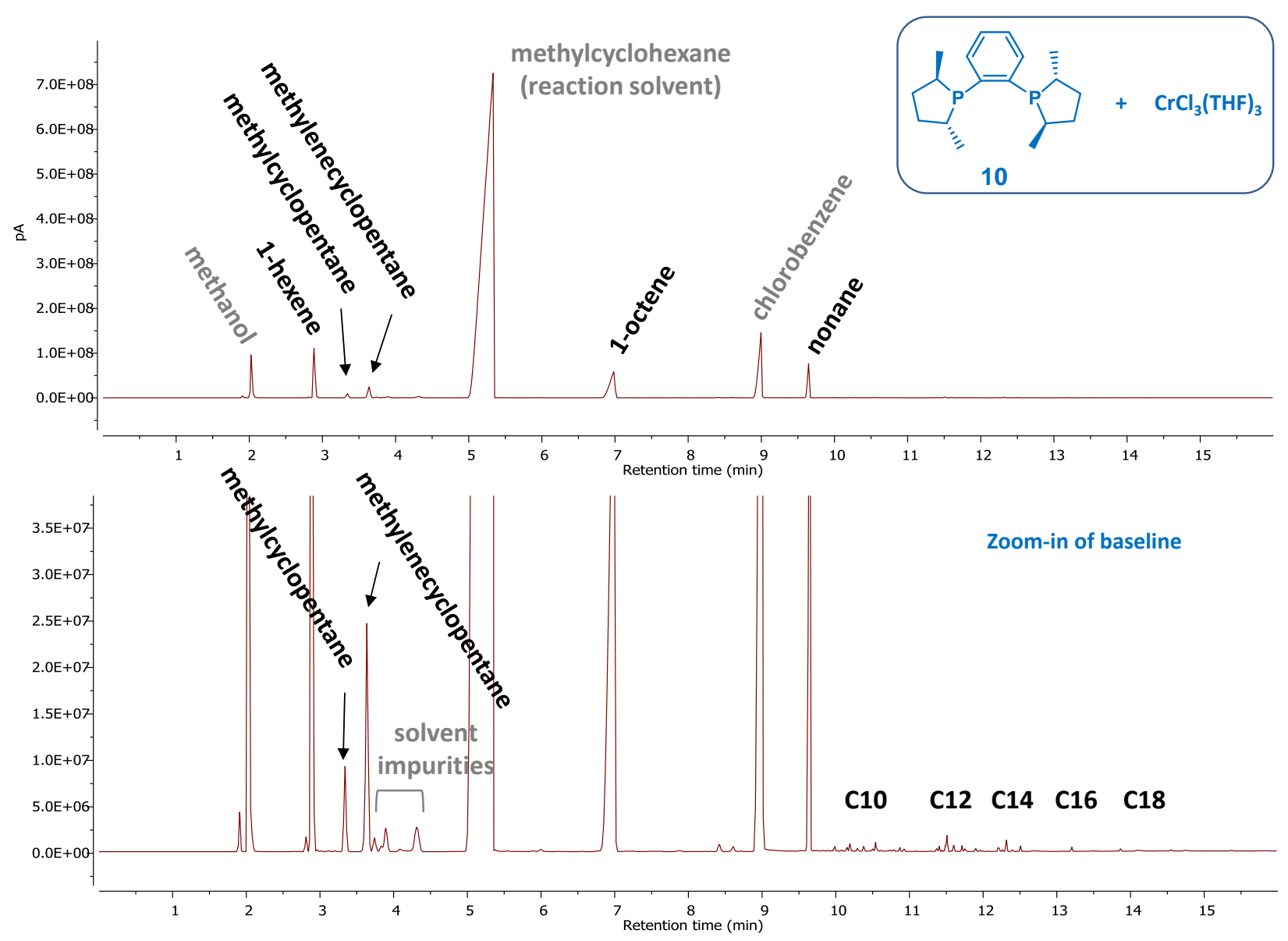




\section{General Synthesis Information}

All reagents were obtained from commercial sources and used as received unless otherwise noted. All syntheses and manipulations of air-sensitive materials were carried out under an inert atmosphere (nitrogen). Solvents (toluene, hexane, diethyl ether) were first saturated with nitrogen and then dried by passage through activated alumina and Q-5TM catalyst (available from Engelhard Chemicals, Inc.) prior to use. $\mathrm{C}_{6} \mathrm{D}_{6}$ was dried over $\mathrm{Na} / \mathrm{K}$ and $\mathrm{CDCl}_{3}$ was dried over activated $4 \AA$ molecular sieves before use. NMR spectra were recorded on Varian MR-400 and VNMRS-500 spectrometers. ${ }^{1} \mathrm{H}$ NMR data are reported as follows: chemical shift (multiplicity $(\mathrm{br}=$ broad, $\mathrm{s}=$ singlet, $\mathrm{d}=$ doublet, $\mathrm{t}=$ triplet, $\mathrm{q}=$ quartet, $\mathrm{p}=$ pentet, and $\mathrm{m}=$ multiplet), integration and assignment). Chemical shifts for ${ }^{1} \mathrm{H}$ NMR data are reported in ppm downfield from internal tetramethylsilane (TMS, $\delta$ scale) using residual protons in the deuterated solvents $\left(\mathrm{C}_{6} \mathrm{D}_{6}, 7.15 \mathrm{ppm}: \mathrm{CDCl}_{3}, 7.25 \mathrm{ppm}\right)$ as references. ${ }^{13} \mathrm{C}$ NMR data were determined with ${ }^{1} \mathrm{H}$ decoupling and the chemical shifts are reported in ppm vs tetramethylsilane $\left(\mathrm{C}_{6} \mathrm{D}_{6}, 128 \mathrm{ppm}, \mathrm{CDCl}_{3}, 77 \mathrm{ppm}\right)$. Elemental analyses were performed at Midwest Microlab, LLC. High-throughput catalyst evaluation experiments were conducted according to the published procedure. ${ }^{1}$ 


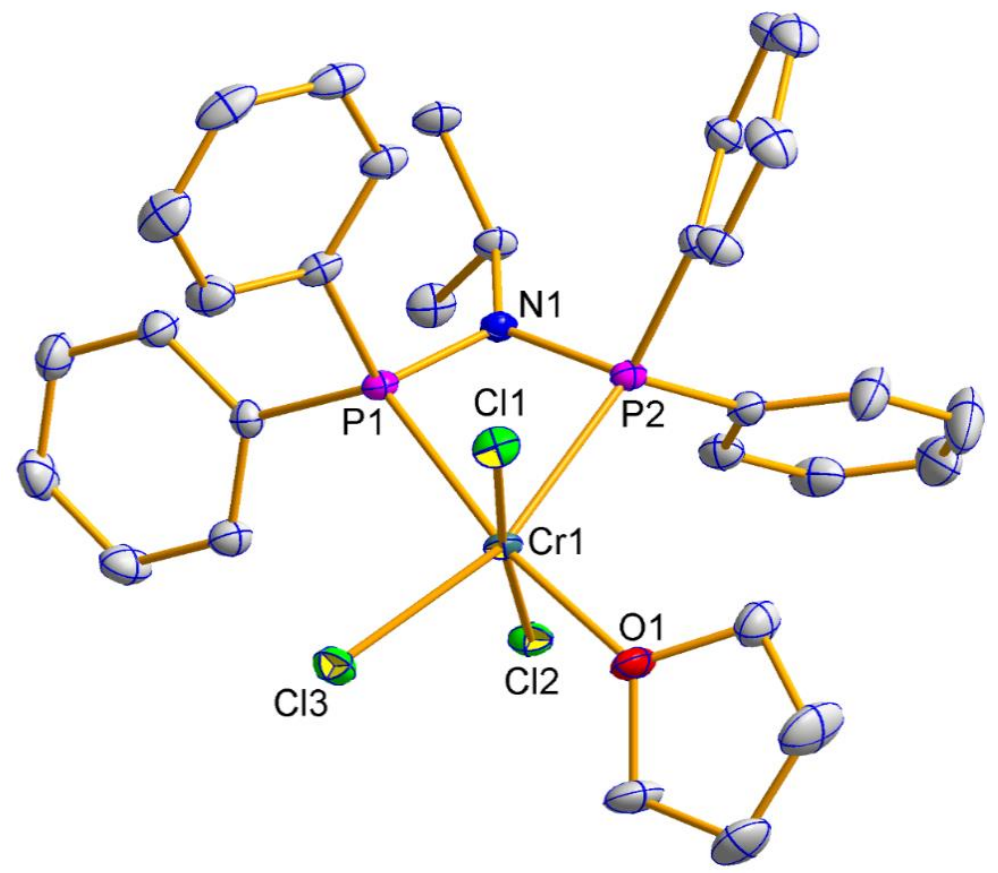

Figure S3. Molecular structure of $i$-Pr-PNP-CrCl 3 (THF) (1-Cr). Thermal ellipsoids are shown at 50\% probability and hydrogen atoms were omitted for clarity. Accession code: CCDC 1958678. 


\section{Synthesis of 4-Cr.}

A solution of $\mathrm{CrCl}_{3} \mathrm{THF}_{3}(0.240 \mathrm{~g}, 0.646 \mathrm{mmol})$ in $\mathrm{CDCl}_{3}(4.0 \mathrm{~mL})$ was added to a solution of cis-1,2bis(diphenylphosphino)ethylene $(0.256 \mathrm{~g}, 0.646 \mathrm{mmol})$ in $\mathrm{CDCl}_{3}(0.50 \mathrm{~mL})$ and the mixture was shaken to give a deep blue color. After standing overnight the color was still deep blue and X-ray quality crystals had formed.

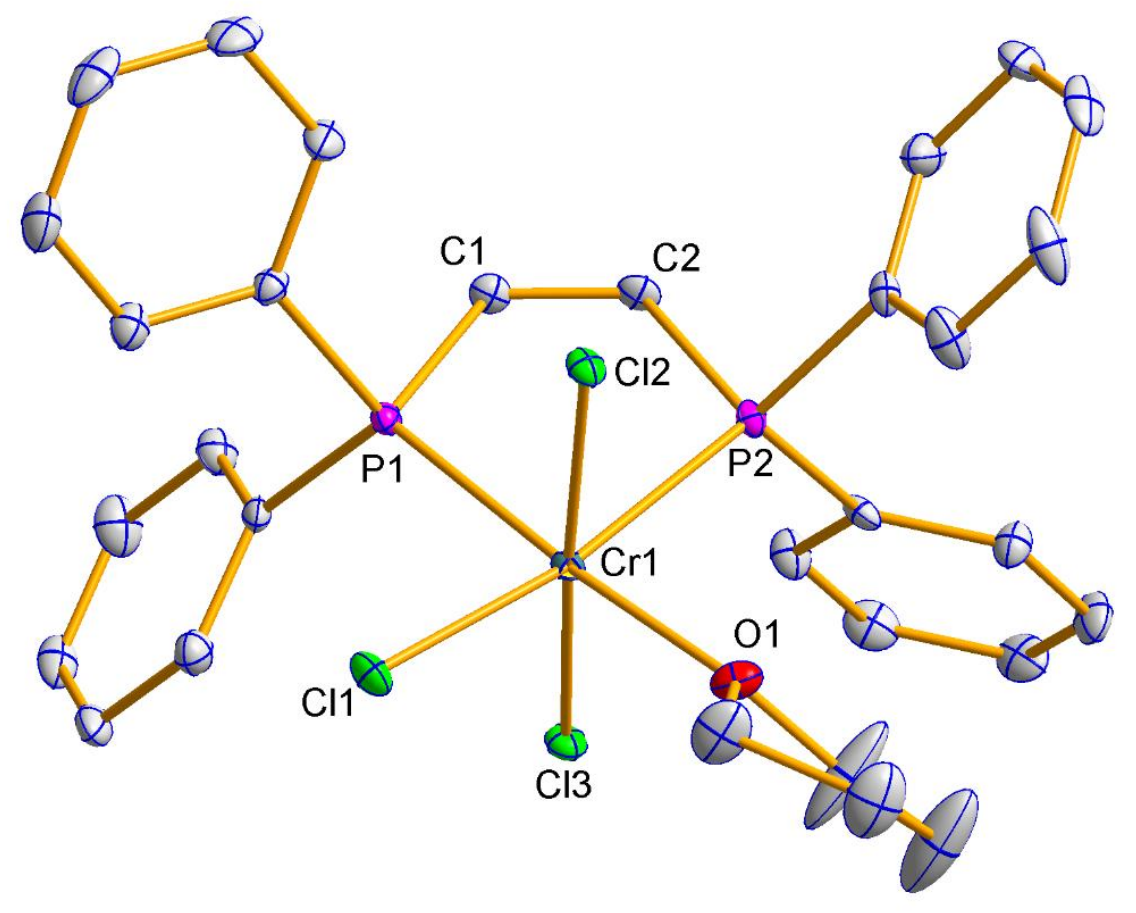

Figure S4. Molecular structure of 4-Cr. Thermal ellipsoids are shown at 50\% probability and hydrogen atoms were omitted for clarity. Accession code: CCDC 1958684. 
Figure S5. ${ }^{1} \mathrm{H}$ and ${ }^{31} \mathrm{P}$ NMR spectra of $(R, R)-M e D u P h o s ~(10)$ in $\mathrm{C}_{6} \mathrm{D}_{6} ;(R, R)-M e D u P h o s(\mathbf{1 0}),(-)-1,2-$ bis $((2 R, 5 R)$-2,5-dimethylphospholano)benzene.
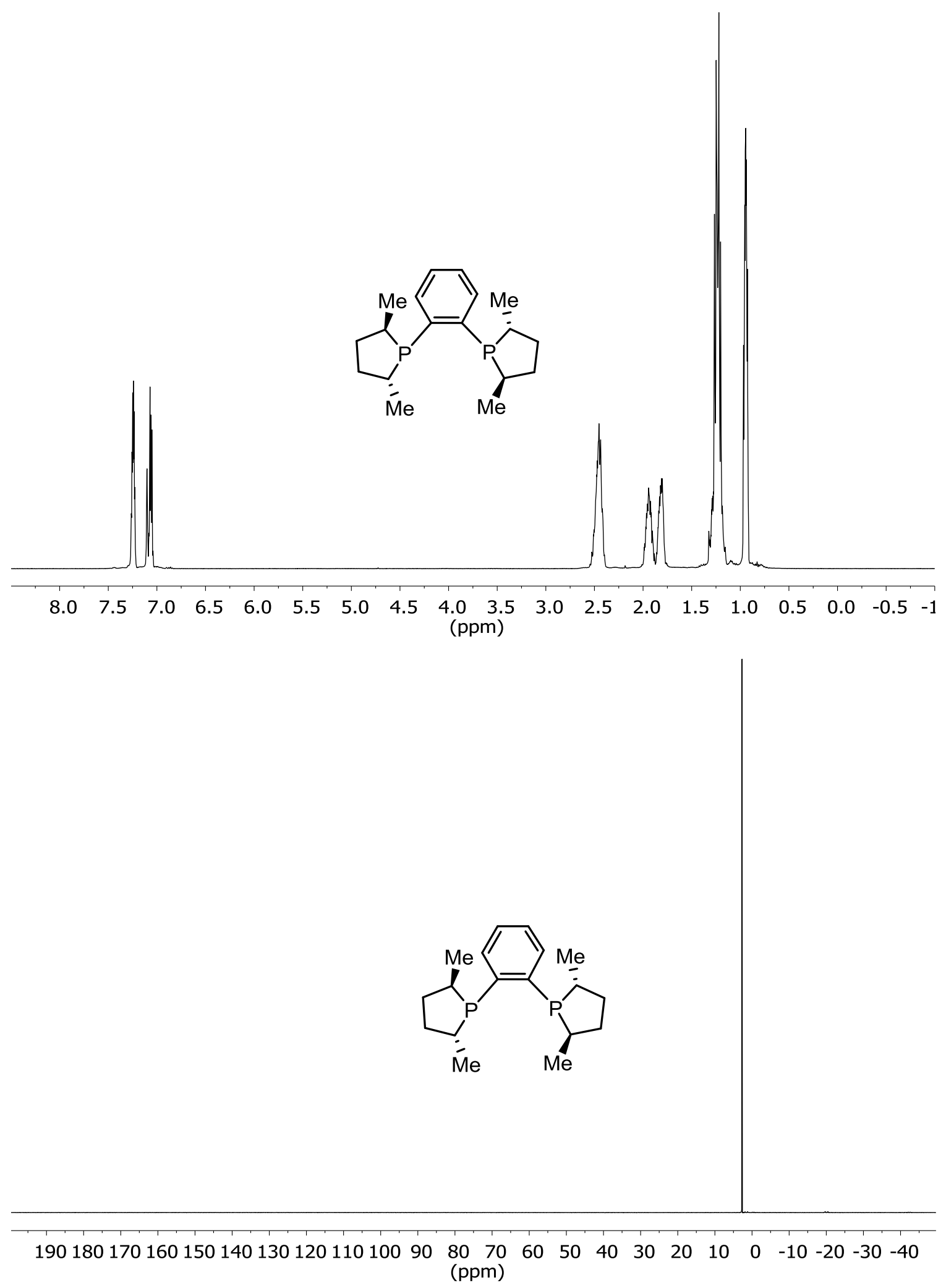
a)

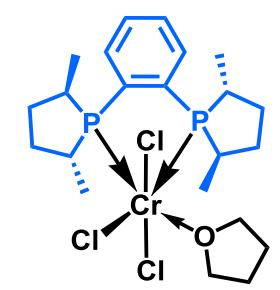

10-Cr
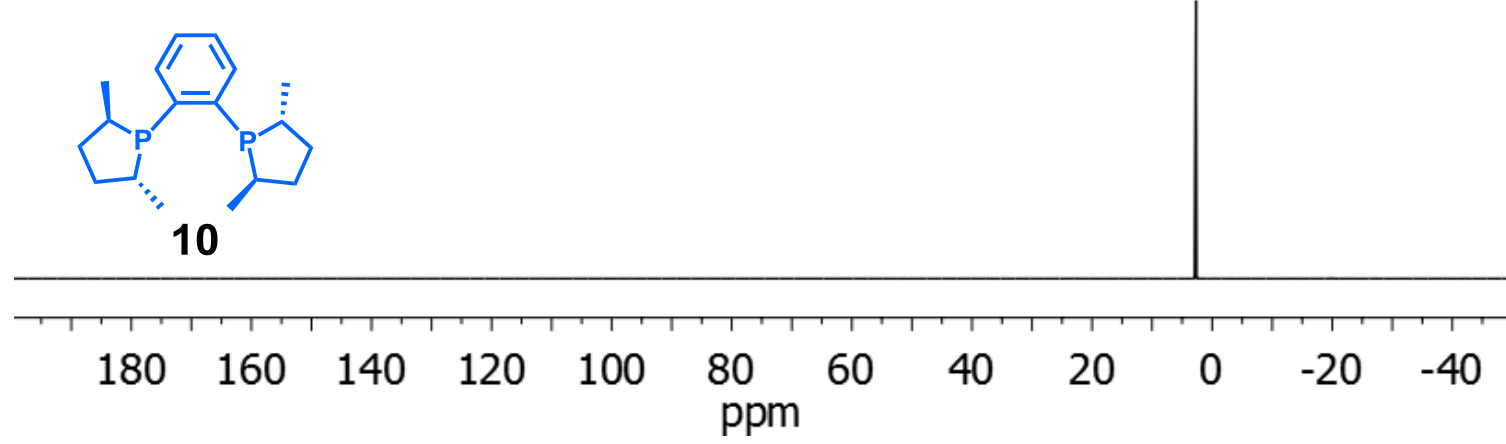

b)

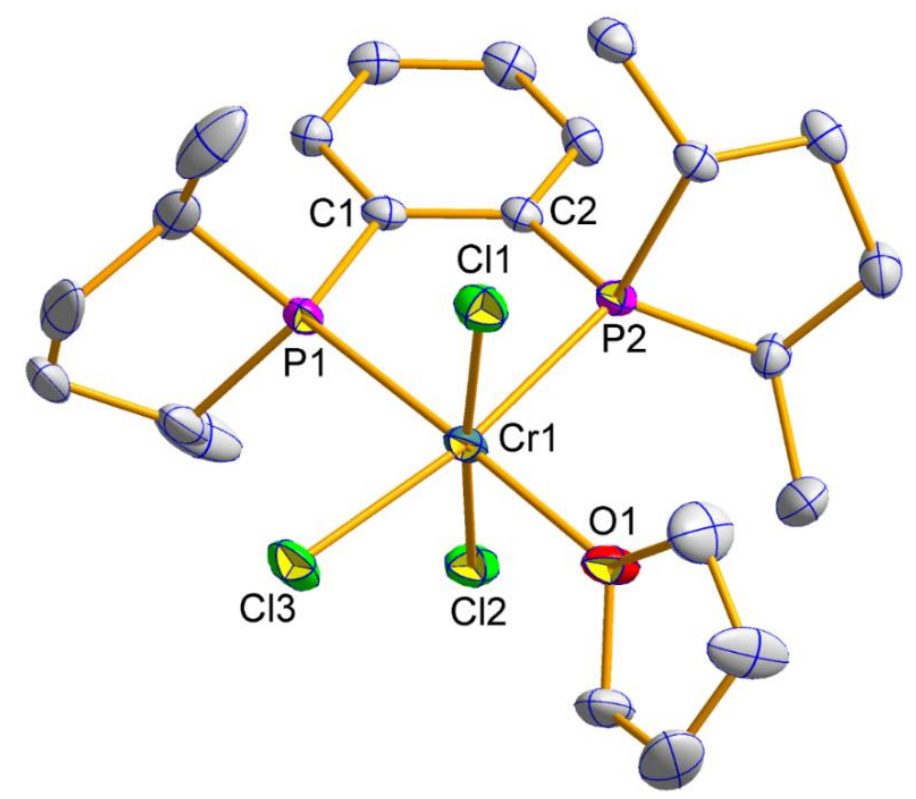

Figure S6. a) ${ }^{31} \mathrm{P}$ NMR spectra of the MeDuPhos ligand (10; bottom spectrum in $\mathrm{C}_{6} \mathrm{D}_{6}$ ) and the MeDuPhos$\mathrm{CrCl}_{3}$ (THF) complex (10-Cr; top spectrum in $\left.\mathrm{CDCl}_{3}\right)$. b) Molecular structure of $(R, R)$-MeDuPhos$\mathrm{CrCl}_{3}$ (THF) (10-Cr). Thermal ellipsoids are shown at 50\% probability and hydrogen atoms were omitted for clarity. Accession code: CCDC 1958682. 


\section{Synthesis of $\left[(S, S)-\mathrm{MeDuPhos}-\mathrm{CrCl}_{2}(\mu-\mathrm{Cl})\right]_{2}$.}

A sample of (S,S)-MeDuPhos-CrCl 3 (THF) prepared as described above for (R,R)-MeDuPhos- $\mathrm{CrCl}_{3}(\mathrm{THF})$ was dissolved in $\mathrm{CD}_{2} \mathrm{Cl}_{2}$. To this solution was added hexane until a small amount of precipitate appeared. The solution was filtered and stored at room temperature for two days during which single crystals formed. Elemental analysis for $\mathrm{C}_{36} \mathrm{H}_{56} \mathrm{Cl}_{6} \mathrm{Cr}_{2} \mathrm{P}_{4}$ : Calculated: $\mathrm{C}, 46.52 ; \mathrm{H}, 6.07$. Found: $\mathrm{C}, 46.32 ; \mathrm{H}, 5.97$.

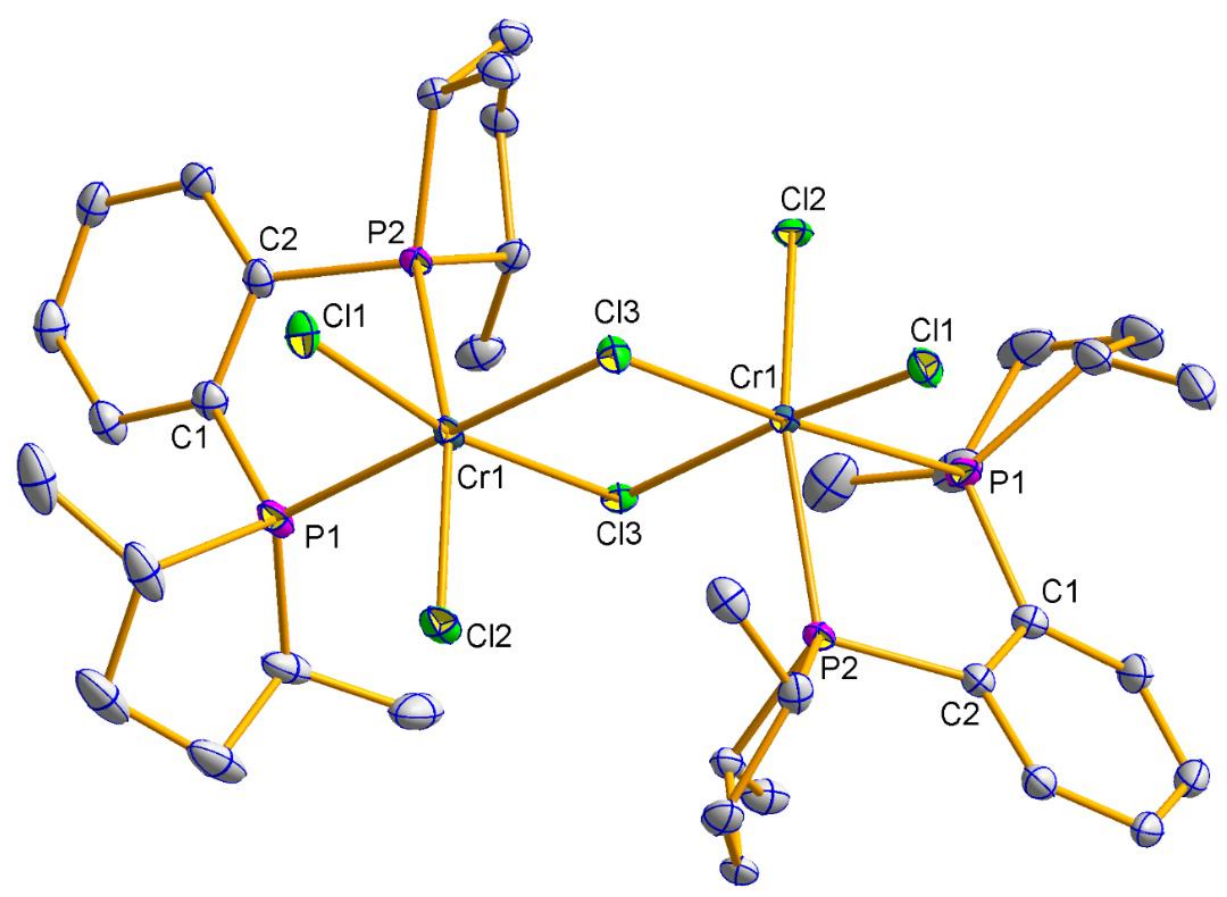

Figure S7. Molecular structure of $\left[(S, S)-\mathrm{MeDuPhos}-\mathrm{CrCl}_{2}(\mu-\mathrm{Cl})\right]_{2}$. Thermal ellipsoids are shown at 50\% probability and hydrogen atoms were omitted for clarity. Accession code: CCDC 1958683. 
Figure S8. ${ }^{1} \mathrm{H}$ and ${ }^{31} \mathrm{P}$ NMR spectra of $(R, R)-\mathrm{MeDuPhos}-\mathrm{CrCl}_{3}(\mathrm{THF})(\mathbf{1 0}-\mathrm{Cr})$ in $\mathrm{CDCl}_{3}$.
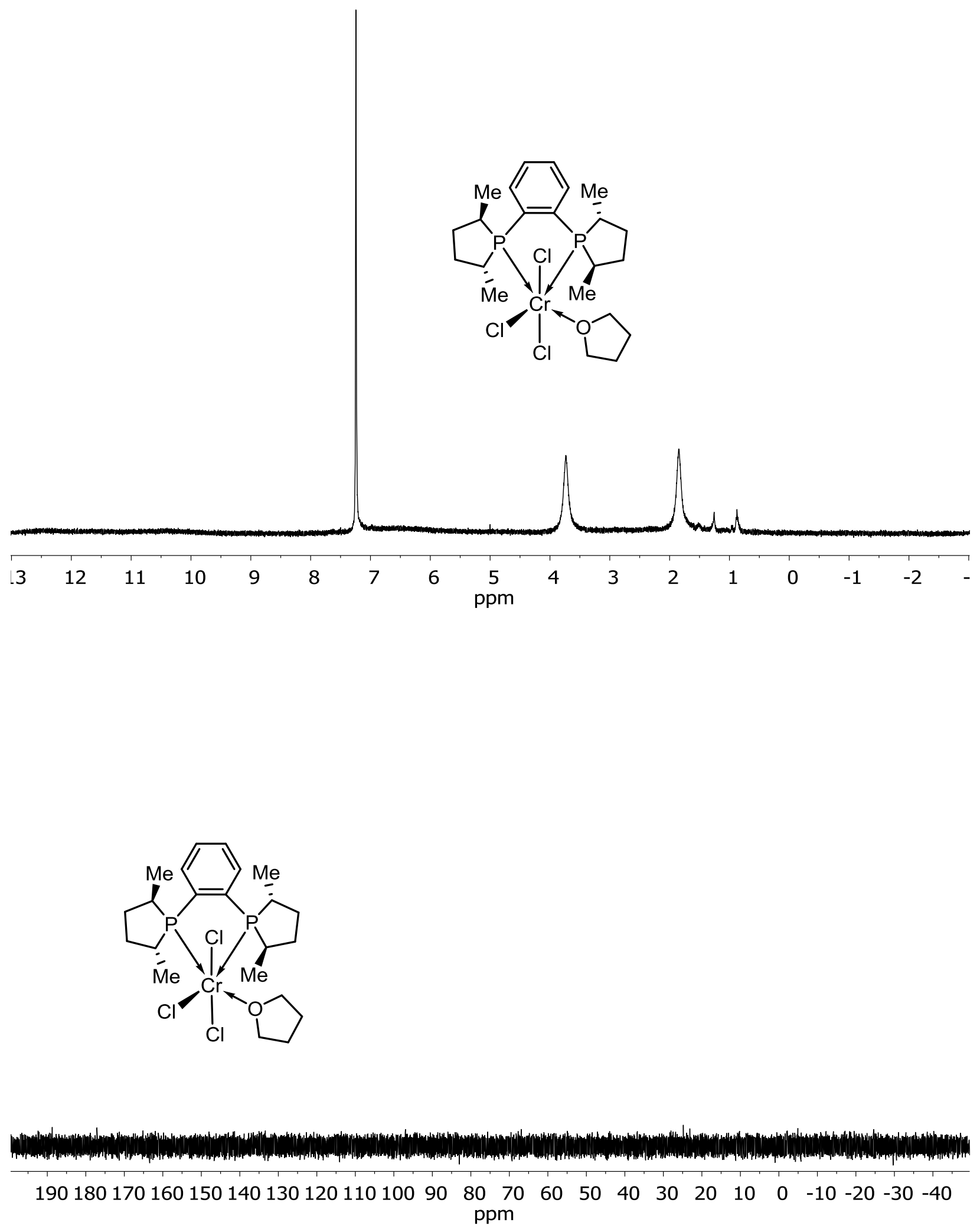
Figure S9. ${ }^{1} \mathrm{H}$ and ${ }^{31} \mathrm{P}$ NMR spectra of $(R, R)$-EtDuPhos (11) in $\mathrm{CDCl}_{3} ;(R, R)$-EtDuPhos = (-)-1,2bis((2R,5R)-2,5-diethylphospholano)benzene.

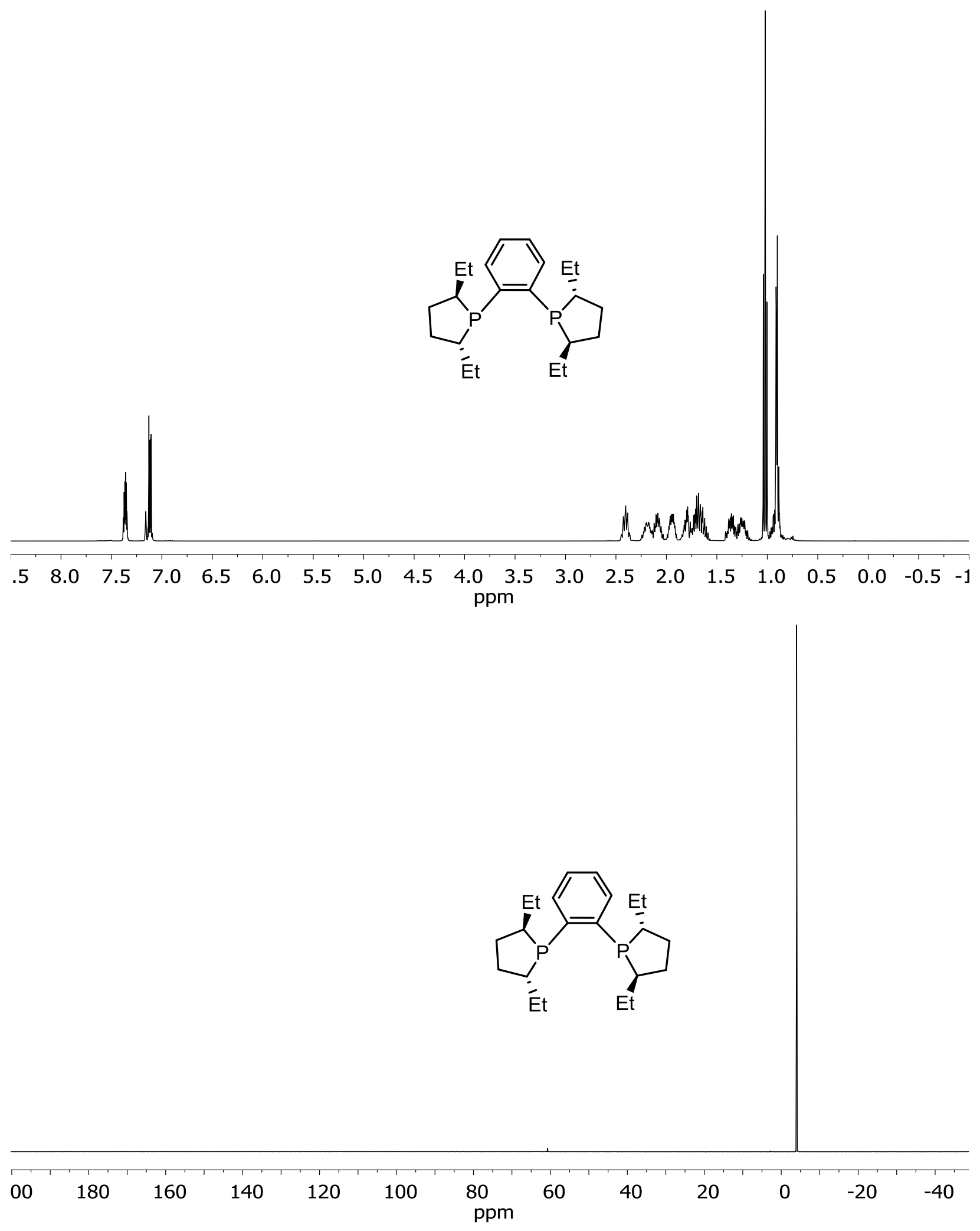




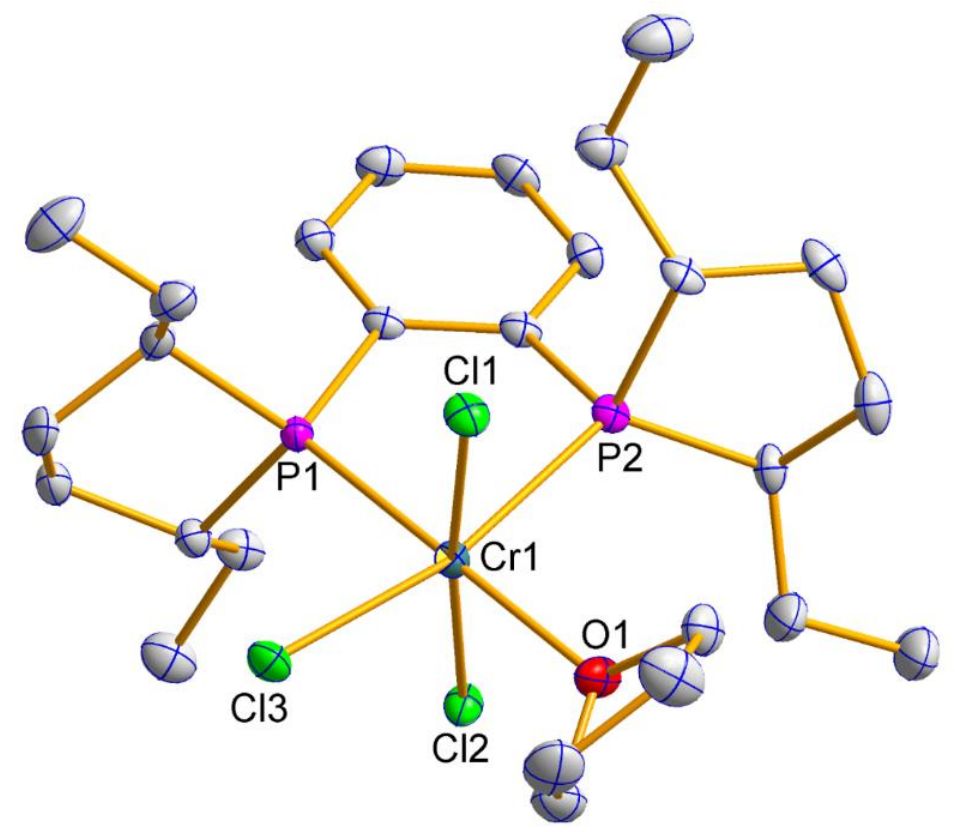

Figure S10. Molecular structure of $(R, R)$-EtDuPhos- $\mathrm{CrCl}_{3}(\mathrm{THF})$ (11-Cr). Thermal ellipsoids are shown at $50 \%$ probability and hydrogen atoms were omitted for clarity. Accession code: CCDC 1958677. 
Figure S11. ${ }^{1} \mathrm{H}$ and ${ }^{31} \mathrm{P}$ NMR spectra of $(R, R)$-EtDuPhos-CrCl 3 (THF) (11-Cr) in $\mathrm{CDCl}_{3}$.
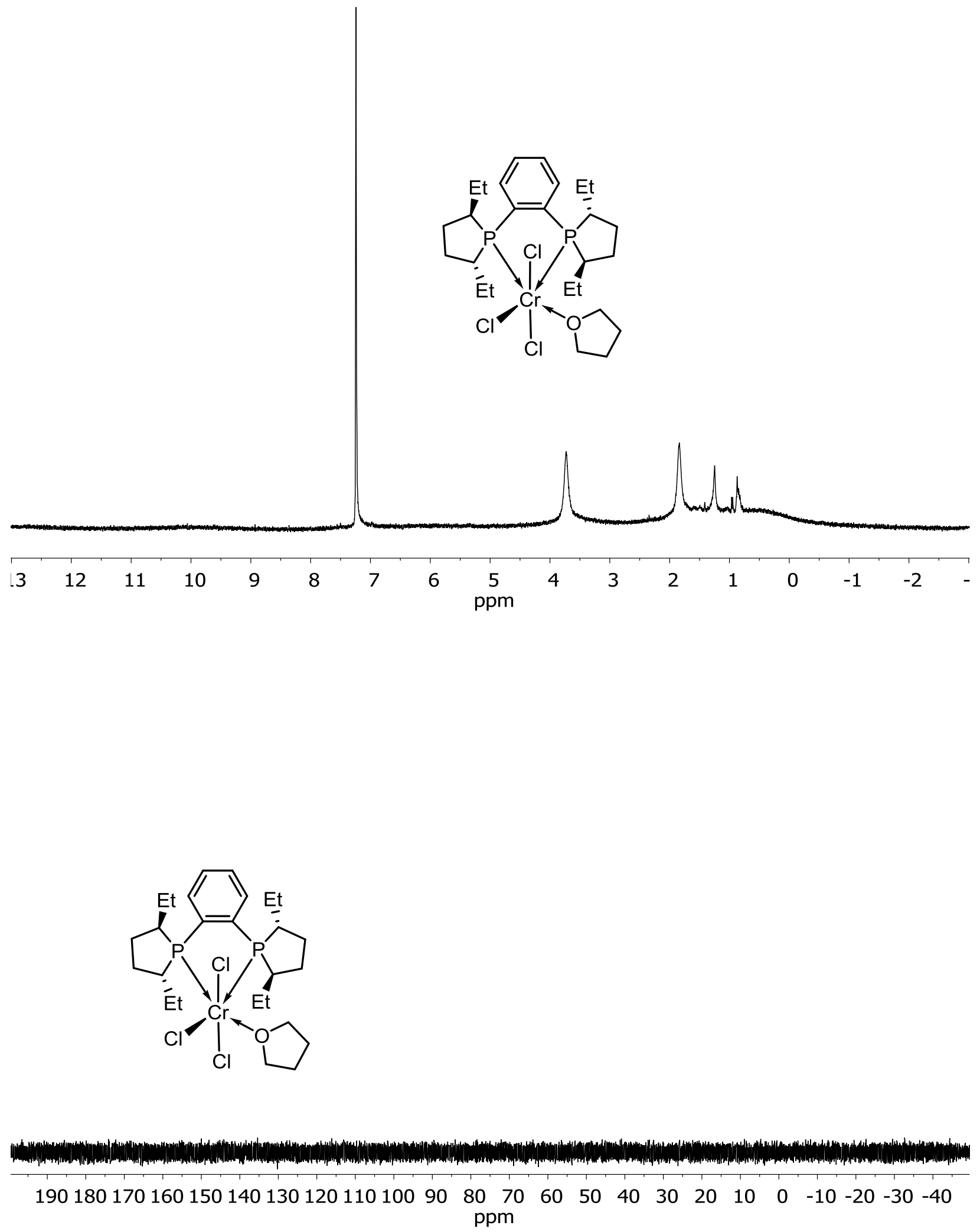
Figure S12. ${ }^{1} \mathrm{H}$ and ${ }^{31} \mathrm{P}$ NMR spectra of $(S, S)$-iPrDuPhos (12) in $\mathrm{CDCl}_{3} ;(S, S)$-iPrDuPhos, (-)-1,2bis((2S,5S)-2,5-di-i-propylphospholano)benzene.
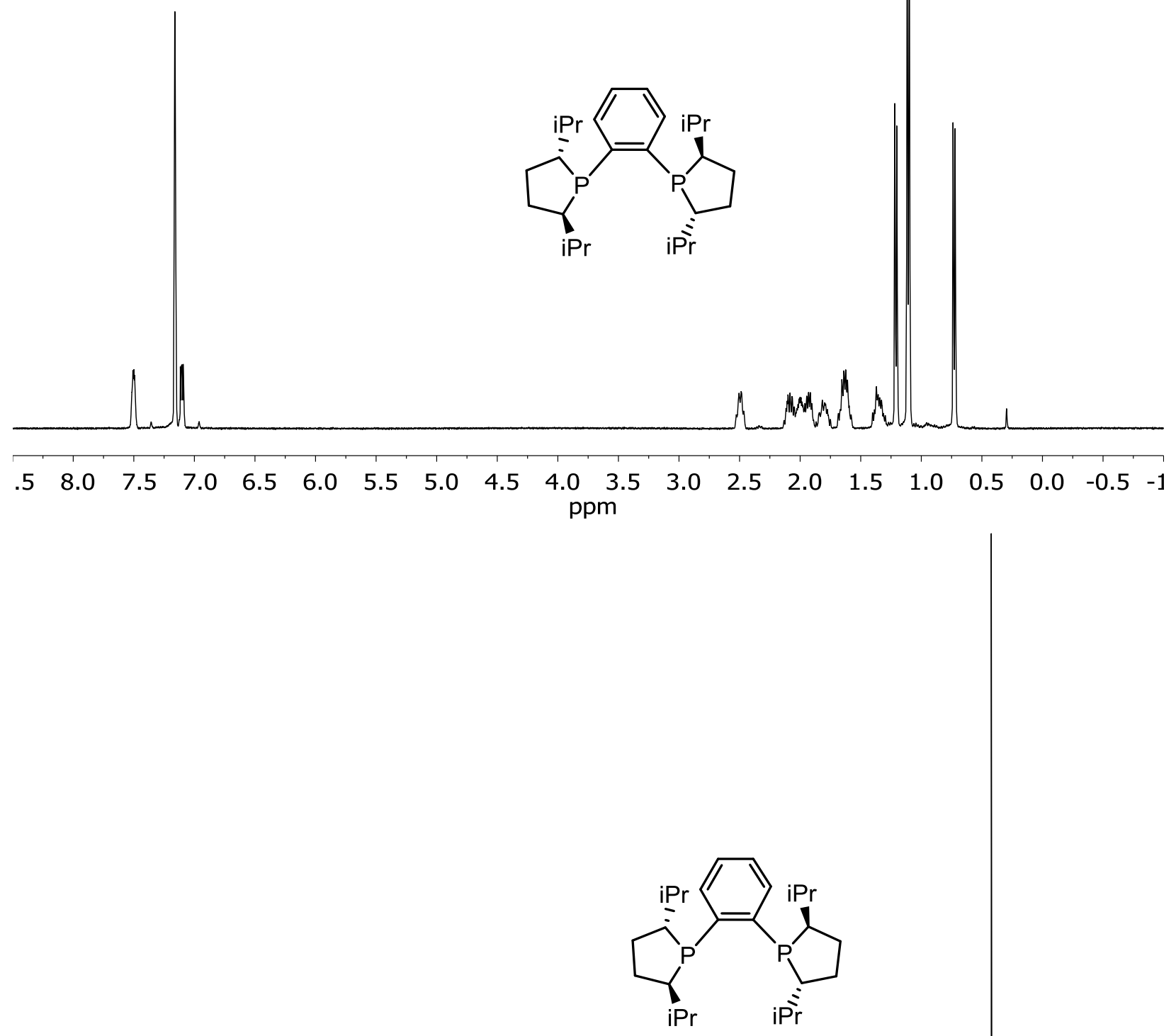

$19018017016015014013012011010090 \quad 80 \quad 70 \quad 60 \quad 50 \quad 40 \quad 30 \quad 20 \quad 10 \quad 0 \quad-10-20-30-40$ ppm 


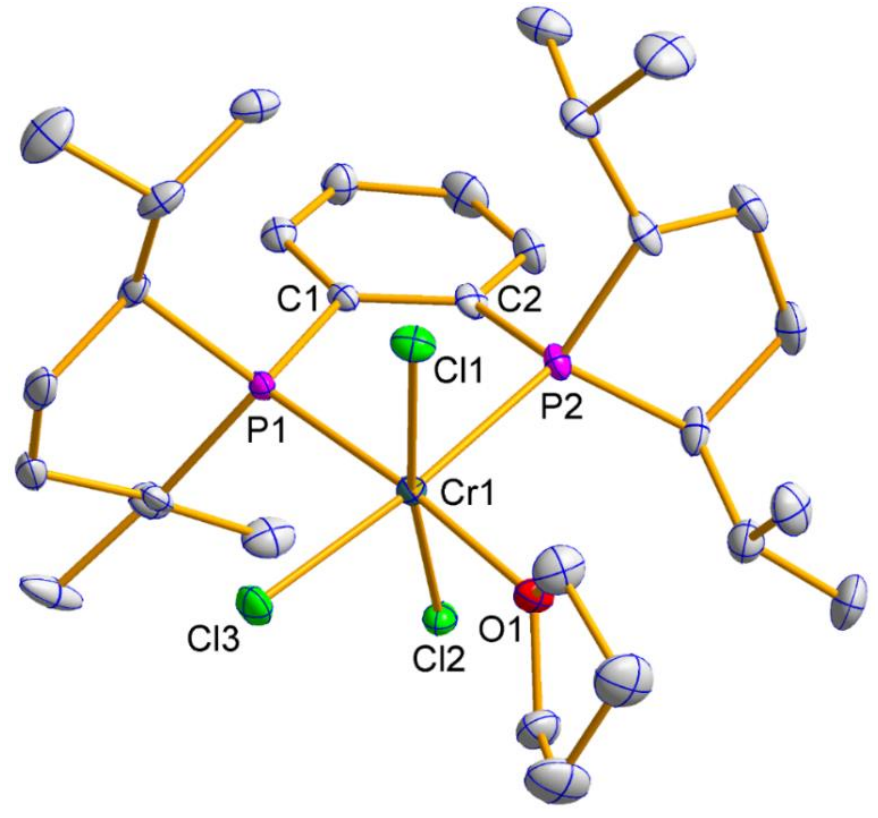

Figure S13. Molecular structure of $(S, S)$-iPrDuPhos- $\mathrm{CrCl}_{3}(\mathrm{THF})$ (12-Cr). Thermal ellipsoids are shown at $50 \%$ probability and hydrogen atoms were omitted for clarity. Accession code: CCDC 1960323. 
Figure S14. ${ }^{1} \mathrm{H}$ and ${ }^{31} \mathrm{P}$ NMR spectra of $(S, S)$-iPr-DuPhos-CrCl 3 (THF) (12-Cr) in $\mathrm{CDCl}_{3}$.
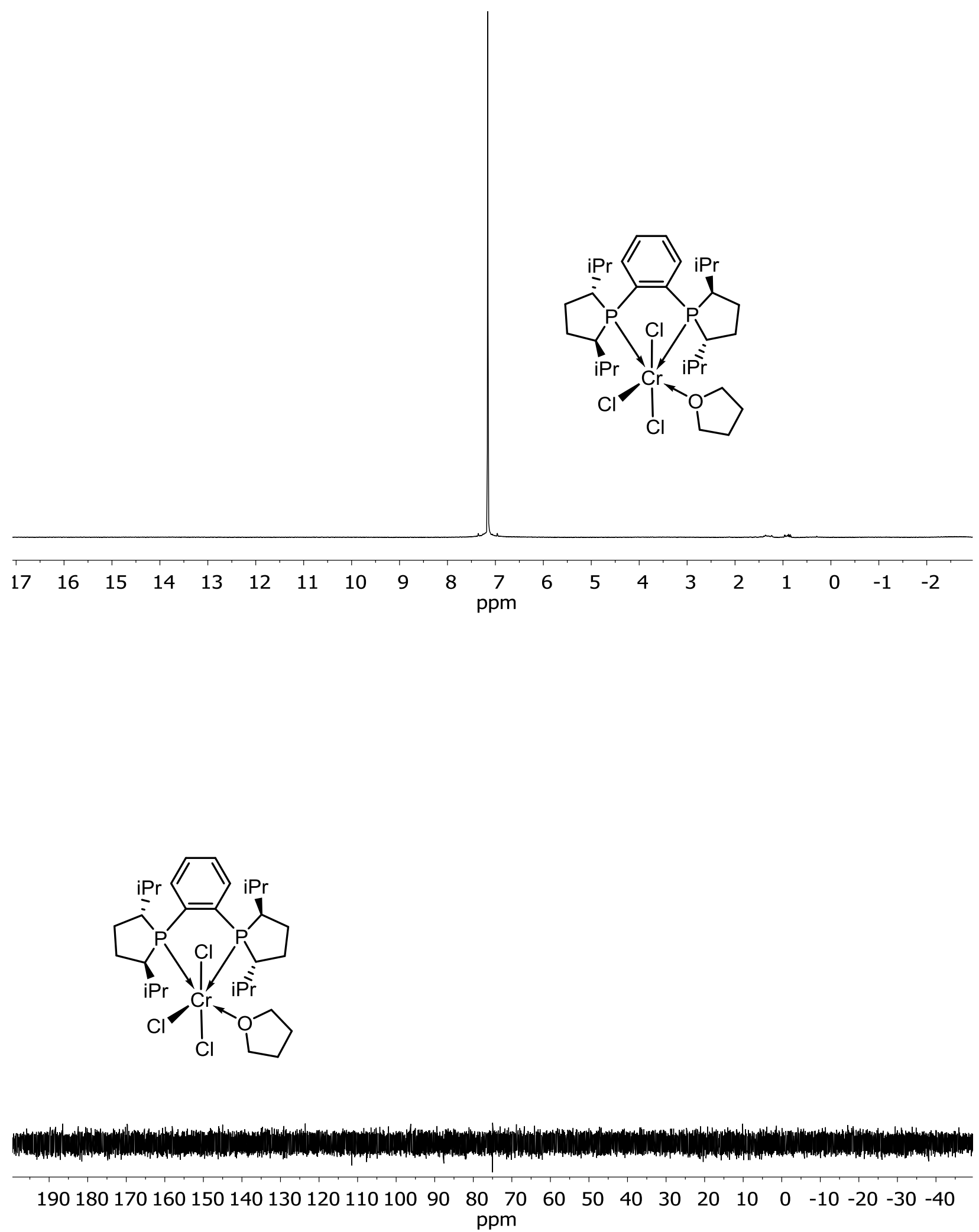
Figure S15. ${ }^{1} \mathrm{H}$ and ${ }^{31} \mathrm{P}$ NMR spectra of $(R, R)-\mathrm{MeBPE}(13)$ in $\mathrm{CDCl}_{3} ;(R, R)-\mathrm{MeBPE},(+)-1,2$-bis $((2 \mathrm{R}, 5 \mathrm{R})$ 2,5-dimethylphospholano)ethane.

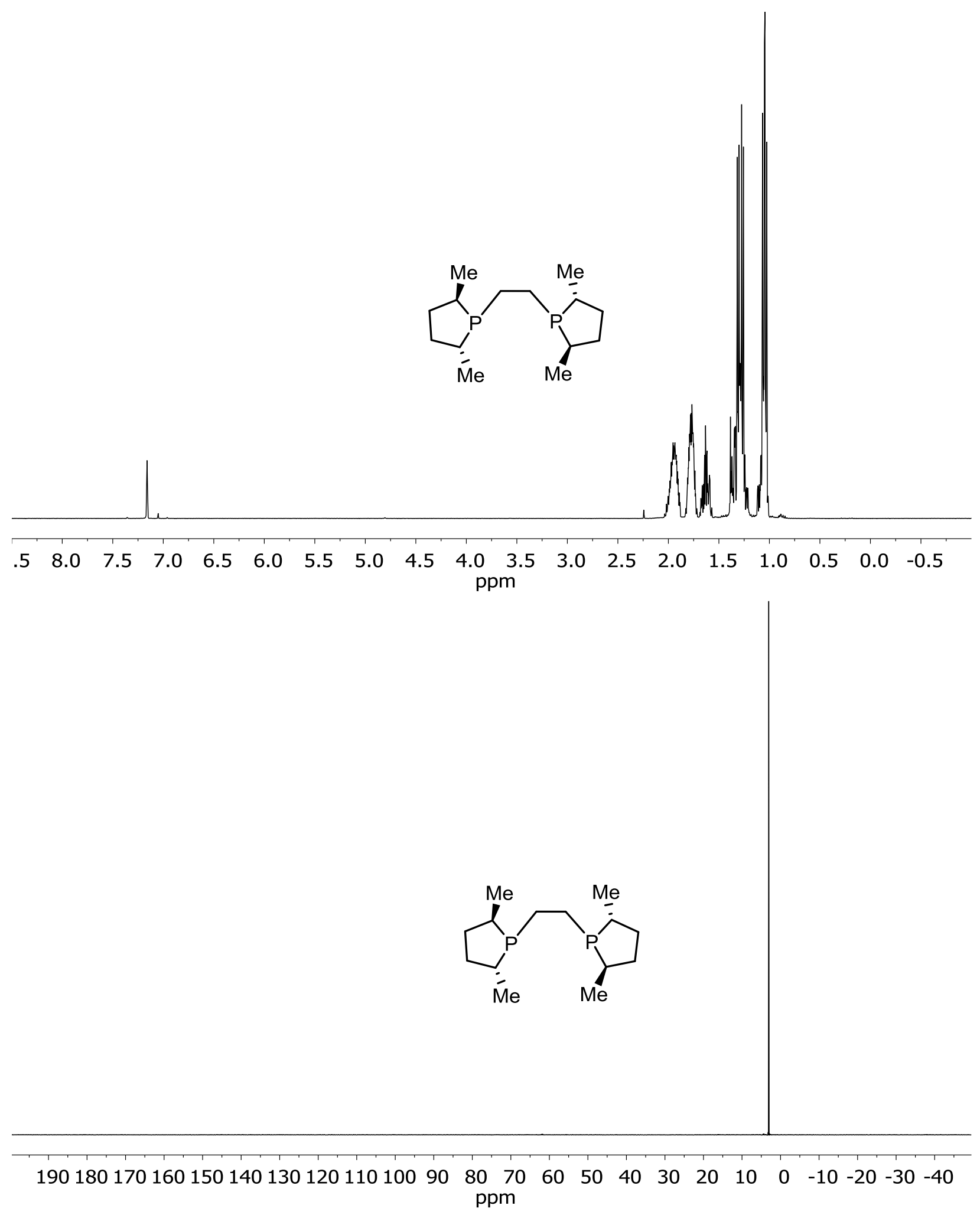




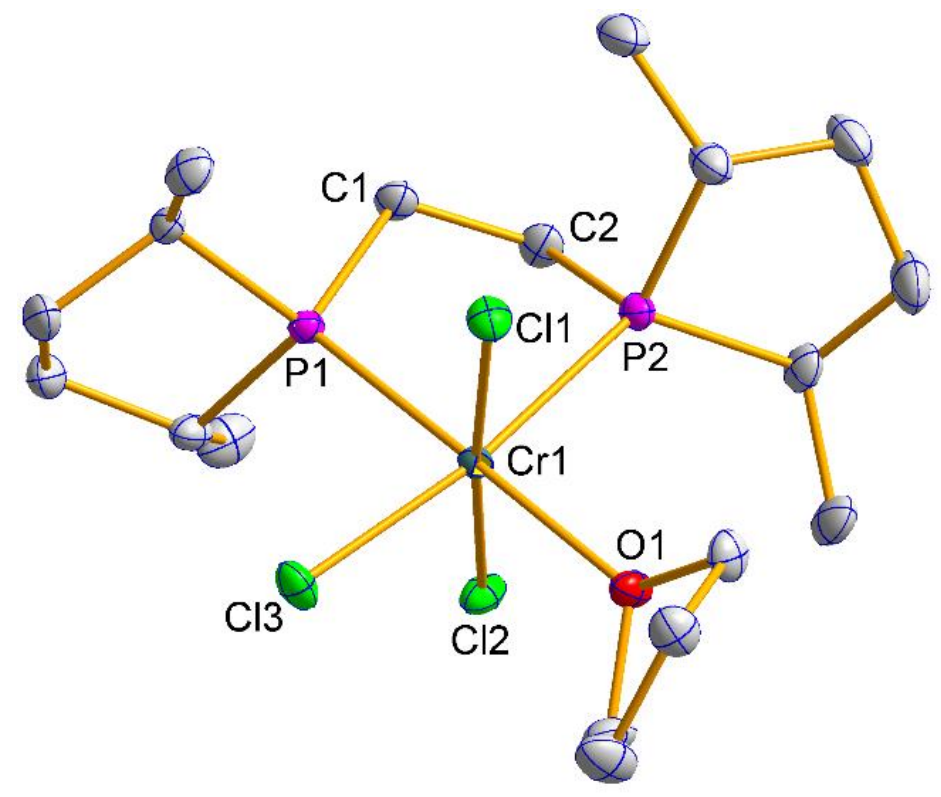

Figure S16. Molecular structure of $(R, R)$-MeBPE- $\mathrm{CrCl}_{3}$ (THF) (13-Cr). Thermal ellipsoids are shown at $50 \%$ probability and hydrogen atoms were omitted for clarity. Accession code: CCDC 1958679. 
Figure S17. ${ }^{1} \mathrm{H}$ and ${ }^{31} \mathrm{P}$ NMR spectra of $(R, R)-\mathrm{MeBPE}-\mathrm{CrCl}_{3}(\mathrm{THF})(\mathbf{1 3 - C r})$ in $\mathrm{CDCl}_{3}$.
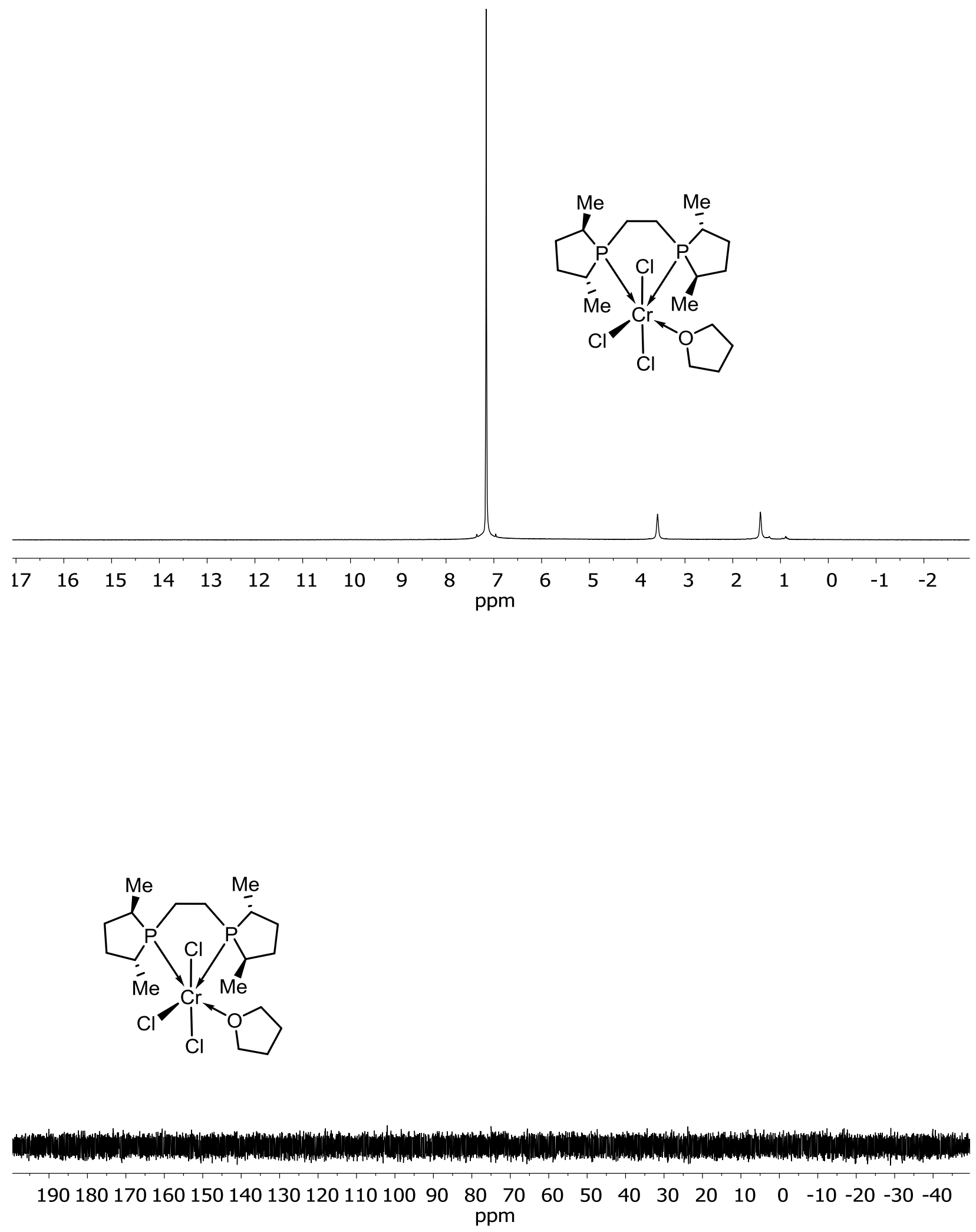
Figure S18. ${ }^{1} \mathrm{H}$ and ${ }^{31} \mathrm{P}$ NMR spectra of $(R, R)$-EtBPE $(14)$ in $\mathrm{C}_{6} \mathrm{D}_{6} ;(R, R)$-EtBPE, $(+)-1,2$-bis $((2 R, 5 R)-2,5$ diethylphospholano)ethane.

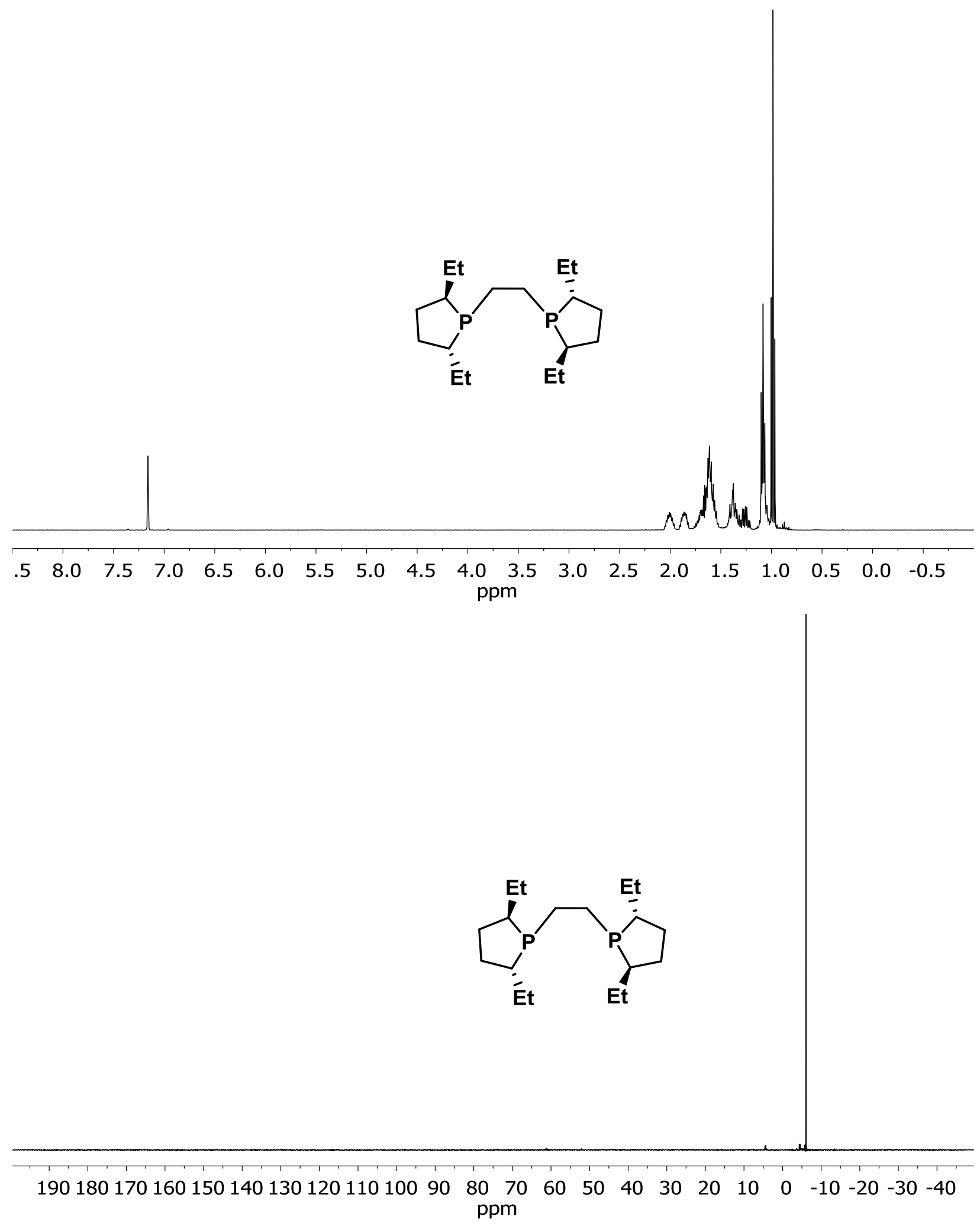


Synthesis of $(R, R)$-EtBPE-CrCl 3 (THF) (14-Cr).<smiles>[R20]C#[R7]CC</smiles>

14

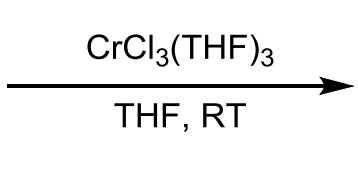

EtBPE-CrCl${ }_{3}$ (THF)

14-Cr

$\mathrm{CrCl}_{3}(\mathrm{THF})_{3}(295 \mathrm{mg}, 0.80 \mathrm{mmol})$ was dissolved in $5 \mathrm{~mL}$ of THF giving a purple solution. To this solution was added a solution of the (R,R)-Et-BPE ligand (14) $(250 \mathrm{mg}, 0.80 \mathrm{mmol})$ dissolved in $5 \mathrm{~mL}$ of THF. The reaction mixture was allowed to stir overnight at ambient temperature and then $30 \mathrm{~mL}$ of hexanes were added. The resulting suspension was filtered through a frit. The solvent was removed from the filtrate in vacuo to yield $354 \mathrm{mg}$ of a blue solid. Yield $81.7 \%$. Crystals suitable for X-ray diffraction analysis were grown by evaporation of a THF/hexanes solution at ambient temperature. Elemental analysis: Calculated: C, 48.49; H, 8.14. Found: C, 43.79; H, 7.84.

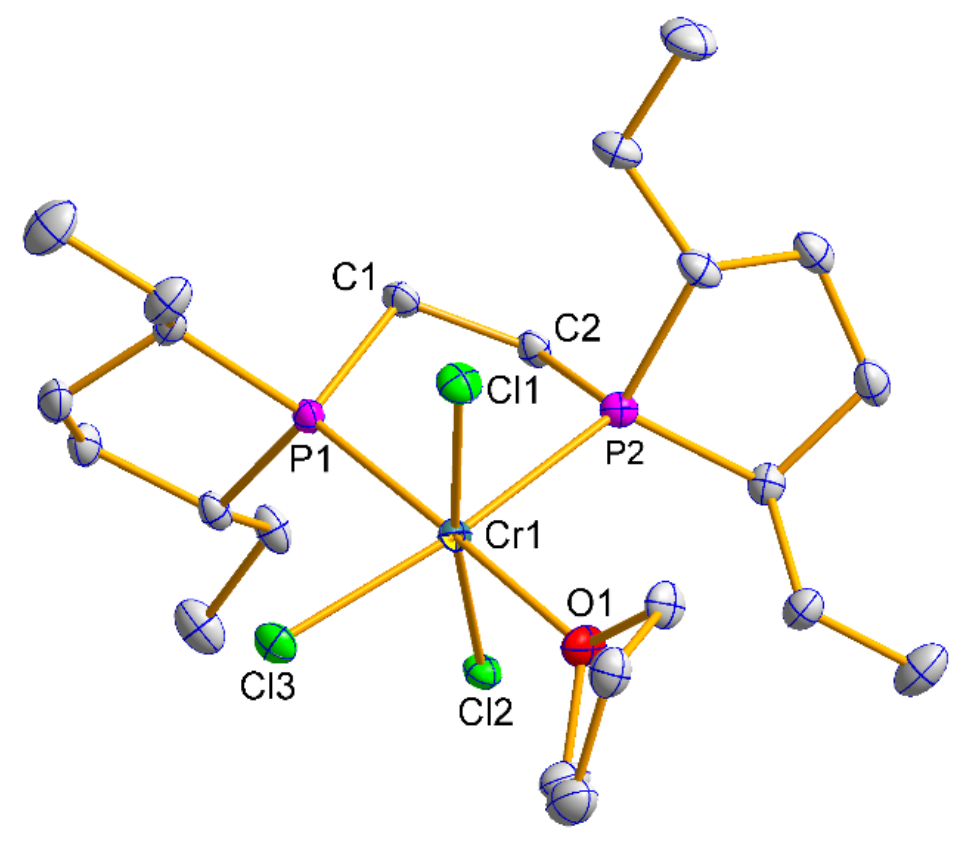

Figure S19. Molecular structure of $(R, R)$-EtBPE-CrCl 3 (THF) (14-Cr). Thermal ellipsoids are shown at $50 \%$ probability and hydrogen atoms were omitted for clarity. Accession code: CCDC 1958680. 
Figure S20. ${ }^{1} \mathrm{H}$ and ${ }^{31} \mathrm{P}$ NMR spectra of $(R, R)$-EtBPE-CrCl $3(\mathrm{THF})(\mathbf{1 4 - C r})$ in $\mathrm{CDCl}_{3}$.
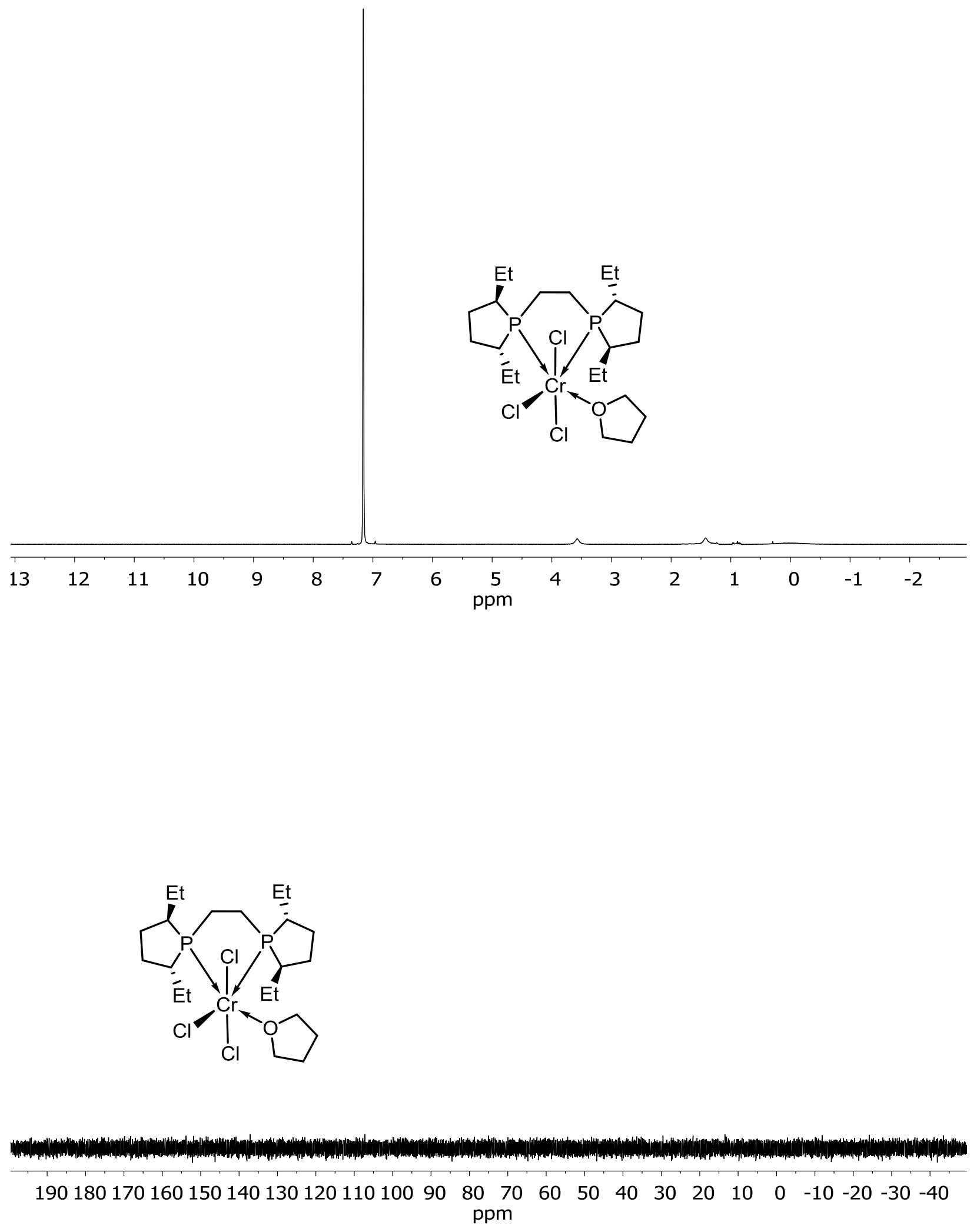


\section{Synthesis of Complex 15-Cr.}

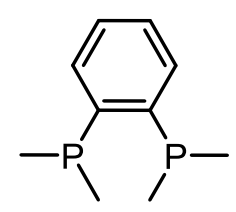

15

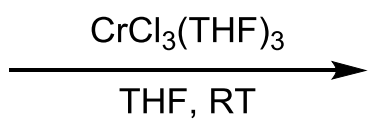

$\mathrm{CrCl}_{3}(\mathrm{THF})_{3}(283.6 \mathrm{mg}, 0.76 \mathrm{mmol})$ was dissolved in $5 \mathrm{~mL}$ of $\mathrm{THF}$ giving a purple solution. To this solution was added a solution of $150 \mathrm{mg}$ of ligand $\mathbf{1 5}(0.76 \mathrm{mmol})$ dissolved in $5 \mathrm{~mL}$ of THF. The reaction mixture was allowed to stir overnight at ambient temperature. The reaction mixture was filtered through a disposable frit, and the solvent was removed from the filtrate in vacuo, yielding $147.1 \mathrm{mg}$ of a blue solid. Yield 45.3\%. Elemental analysis: Calculated: C, 39.23; H, 5.64. Found: C, 35.45; H, 6.36. 
Figure S21. ${ }^{1} \mathrm{H}$ and ${ }^{31} \mathrm{P}$ NMR spectra of Ligand $\mathbf{1 5 -} \mathbf{C r}$ in $\mathrm{CDCl}_{3}$.
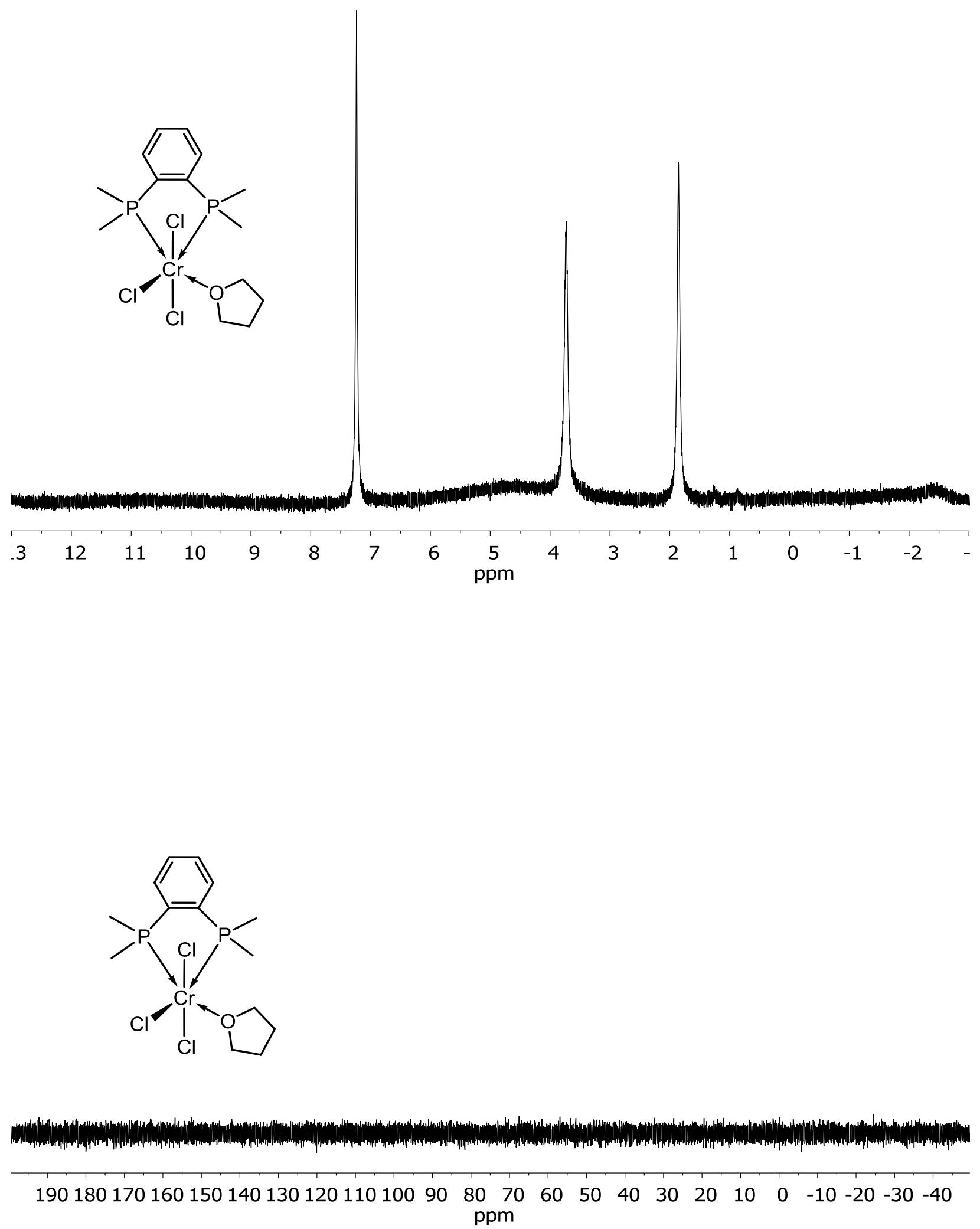


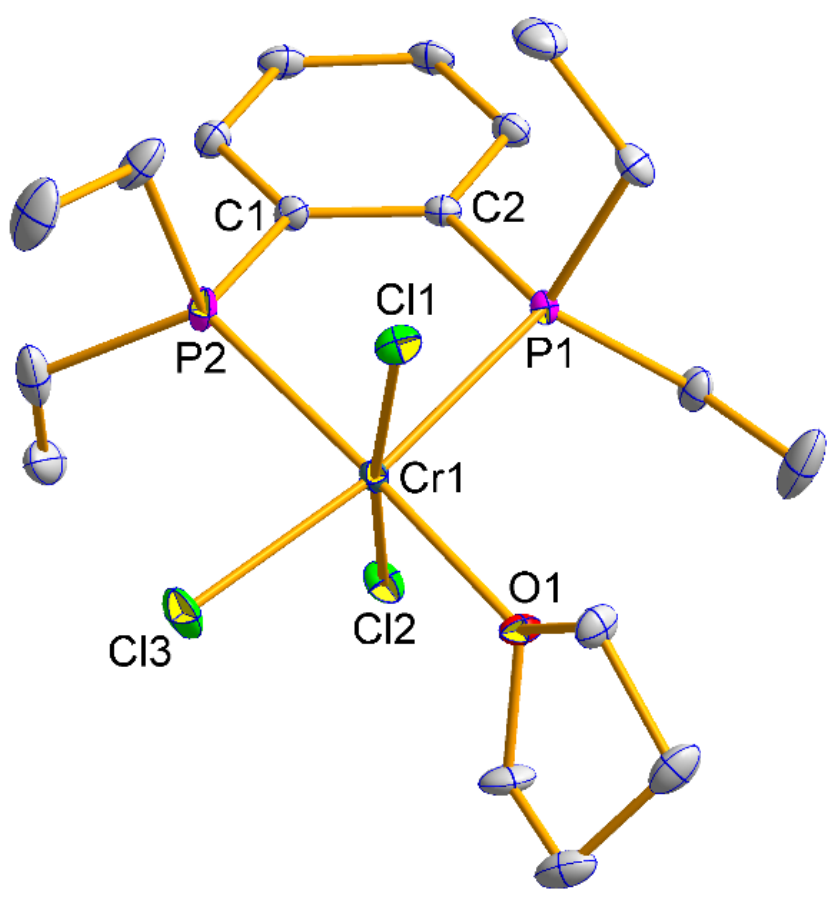

Figure S22. Molecular structure of $9-\mathrm{CrCl}_{3}$ (THF). Thermal ellipsoids are shown at $50 \%$ probability and hydrogen atoms were omitted for clarity. Accession code: CCDC 1958681. 
Figure S23. ${ }^{1} \mathrm{H}$ and ${ }^{31} \mathrm{P}$ NMR spectra of $\mathbf{9 - C r}$ in $\mathrm{CDCl}_{3}$.
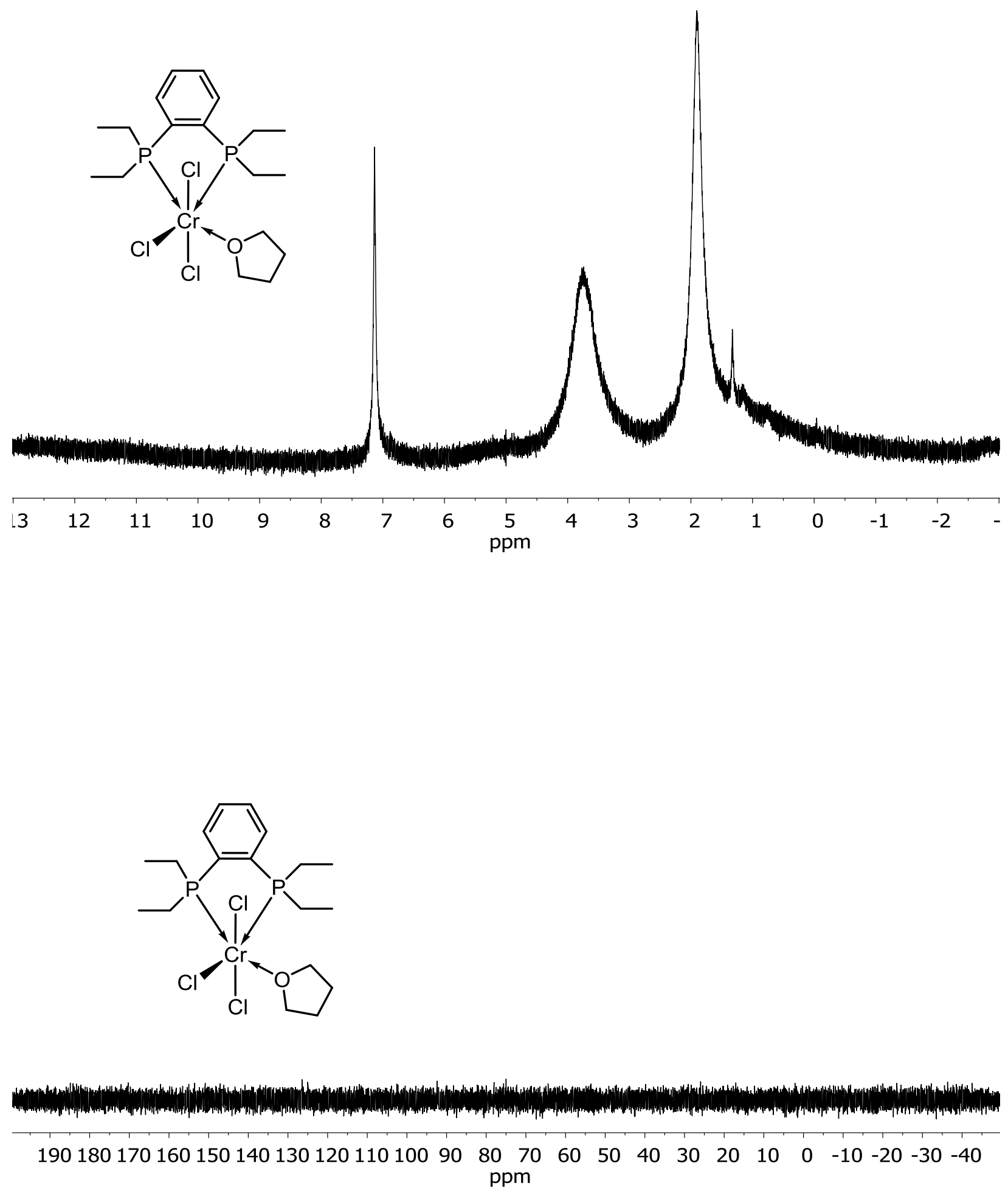


\section{Synthesis of Complex 16-Cr.}
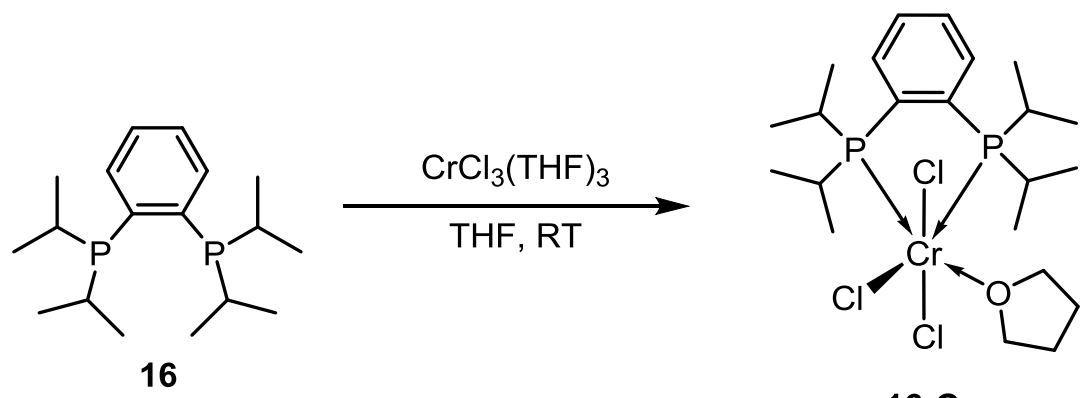

$16-\mathrm{Cr}$

$\mathrm{CrCl}_{3}(\mathrm{THF})_{3}(241.4 \mathrm{mg}, 0.64 \mathrm{mmol})$ was dissolved in $5 \mathrm{~mL}$ of THF giving a purple solution. To this solution was added a solution of $200 \mathrm{mg}$ of ligand $16(0.64 \mathrm{mmol})$ dissolved in $5 \mathrm{~mL}$ of THF. The reaction mixture was allowed to stir for six days at elevated temperature $\left(60^{\circ} \mathrm{C}\right)$. Hexanes $(30 \mathrm{~mL})$ was added to the reaction mixture, and the resulting suspension was filtered through a disposable frit. The solvent was removed from the filtrate in vacuo, yielding $61.2 \mathrm{mg}$ of a blue solid. Yield $17.6 \%$. Elemental analysis: Calculated: C, 48.86; H, 7.45. Found: C, 47.48; H, 7.20. 
Figure S24. ${ }^{1} \mathrm{H}$ and ${ }^{31} \mathrm{P}$ NMR spectra of $\mathbf{1 6 - C r}$ in $\mathrm{CDCl}_{3}$.
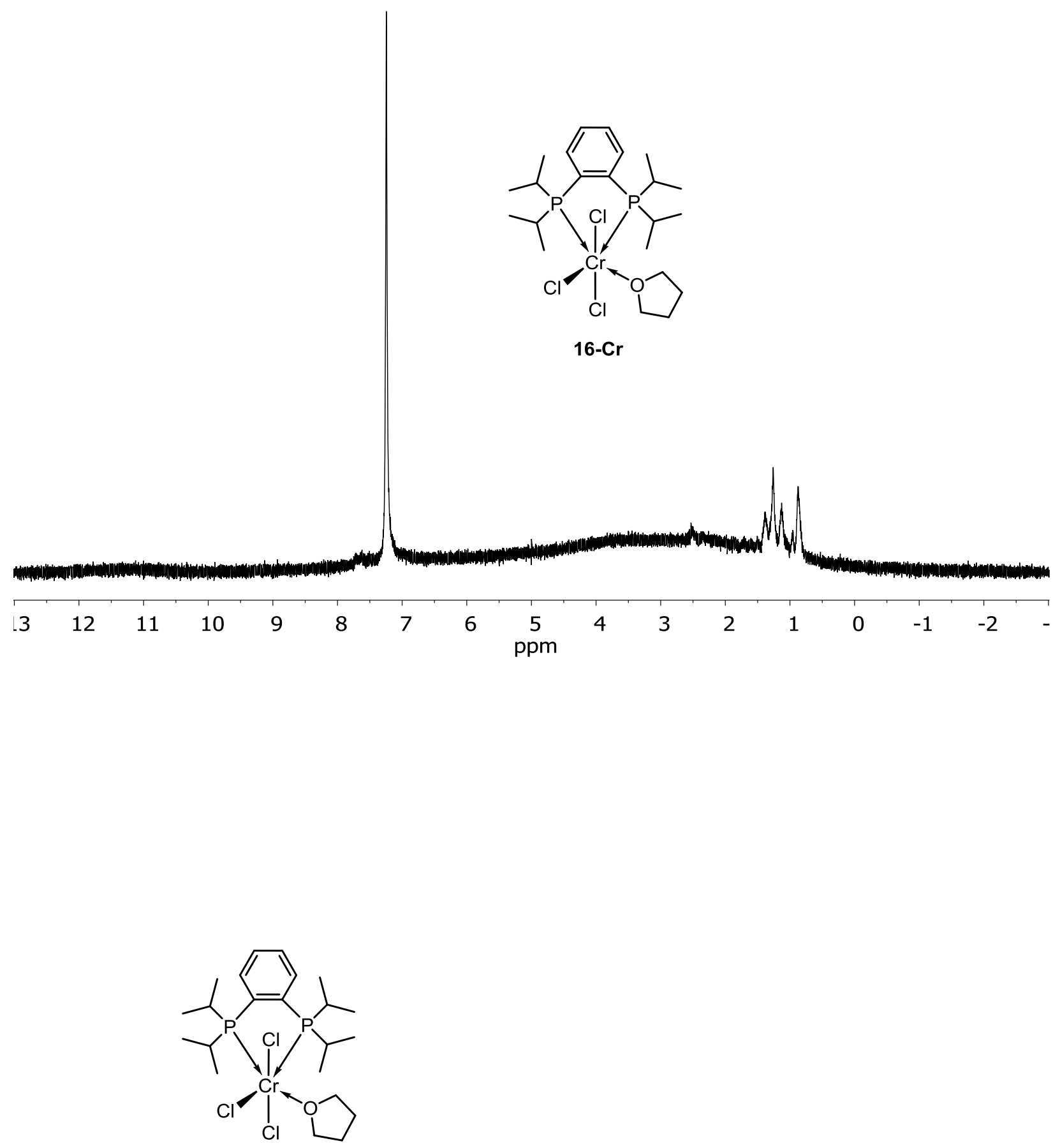

16-Cr 
Figure S25. ${ }^{1} \mathrm{H}$ and ${ }^{31} \mathrm{P}$ NMR spectra of $\mathbf{1 7}$ in $\mathrm{C}_{6} \mathrm{D}_{6}$
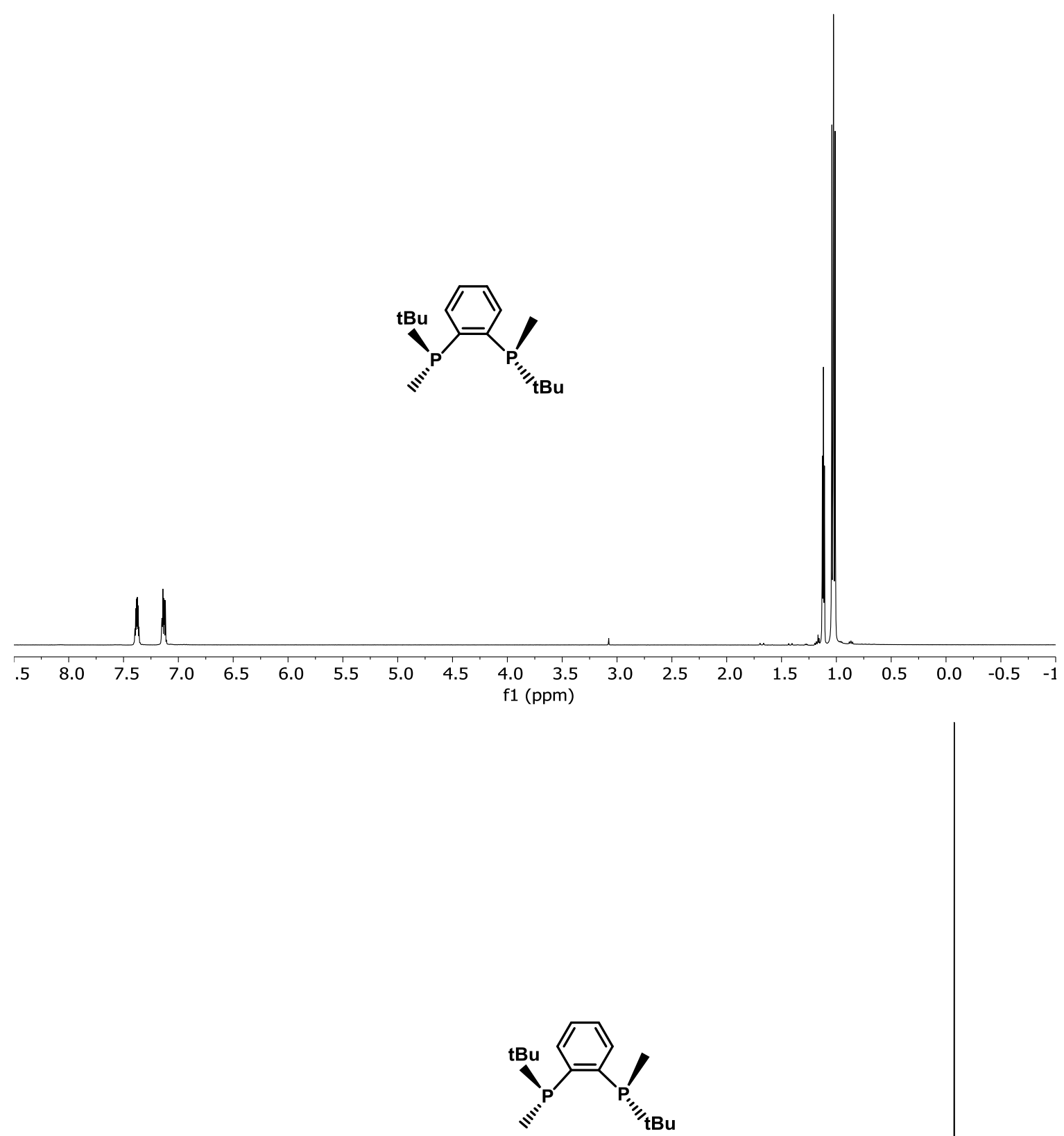


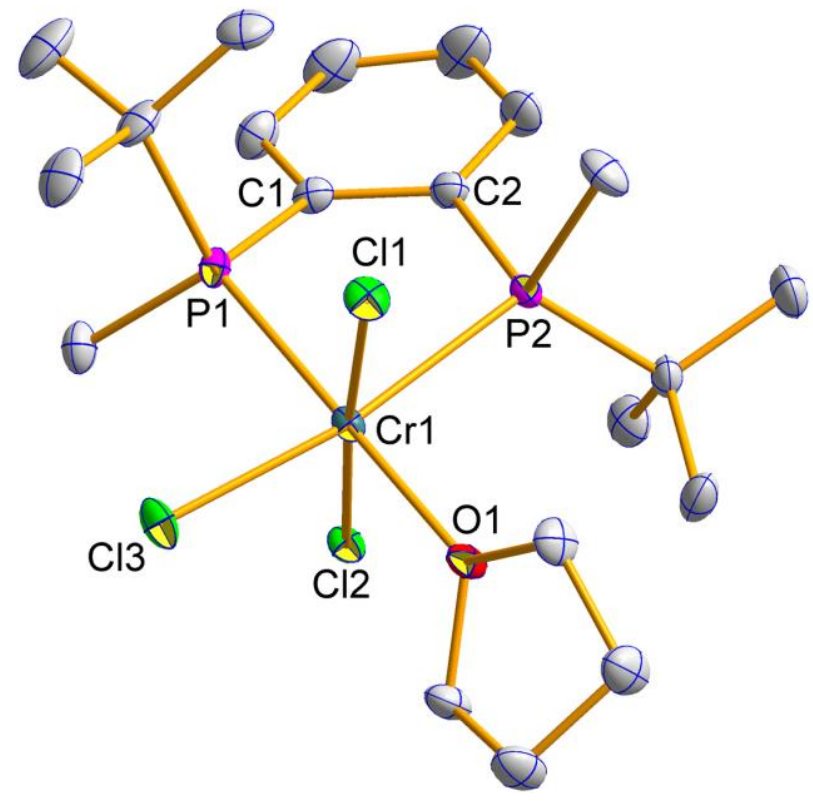

Figure S26. Molecular structure of $(S, S)-17-\mathrm{CrCl}_{3}(\mathrm{THF})$. Thermal ellipsoids are shown at $50 \%$ probability and hydrogen atoms were omitted for clarity. Accession code: CCDC 1960324. 
Figure S27. ${ }^{1} \mathrm{H}$ and ${ }^{31} \mathrm{P}$ NMR spectra of $\mathbf{1 7 -} \mathbf{C r}$ in $\mathrm{CDCl}_{3}$.
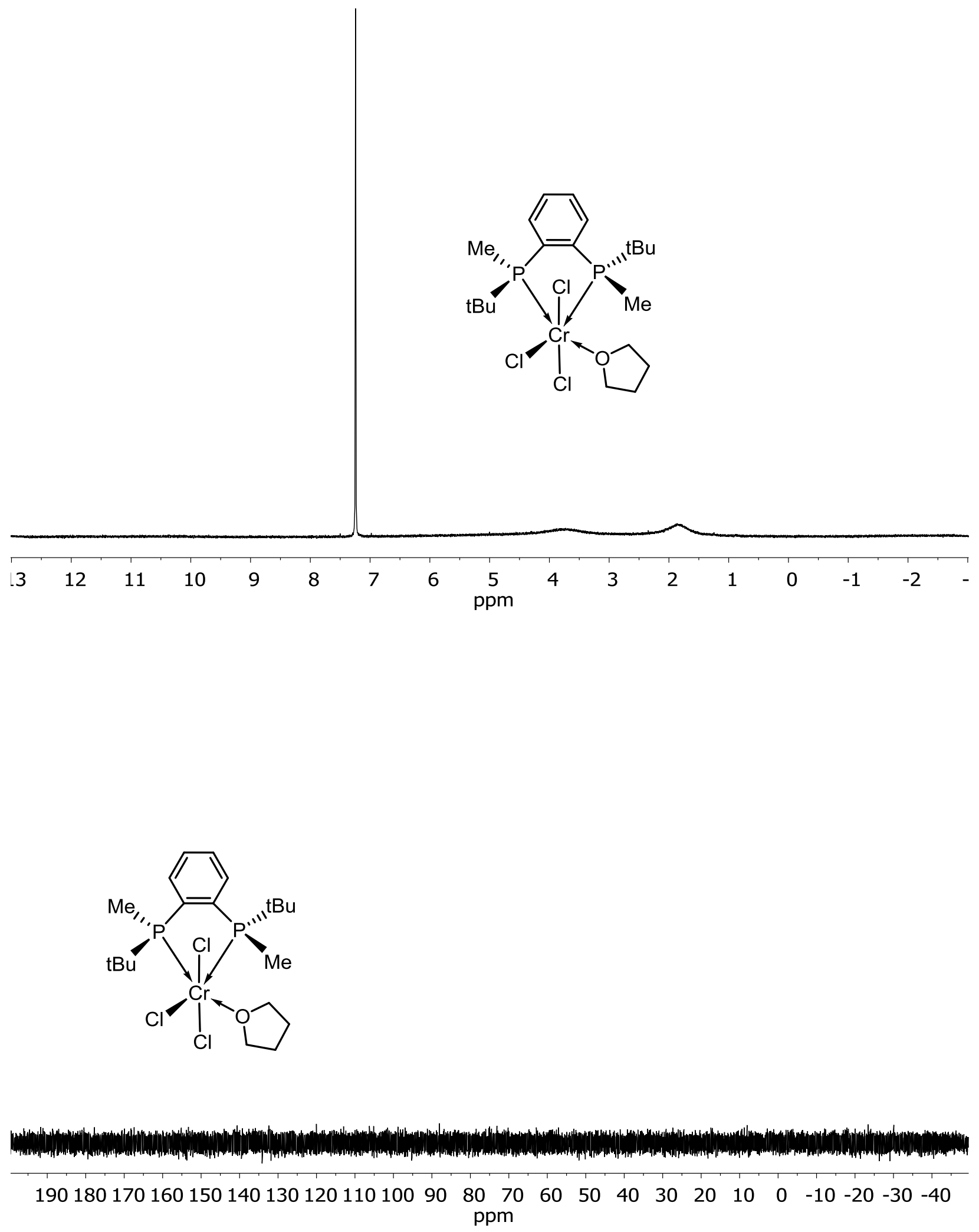
Synthesis of i-Pr-PNP-Cr(CO) $)_{4}$.

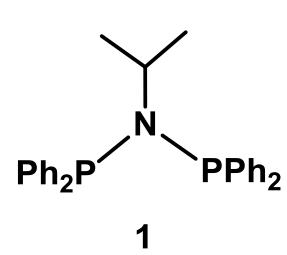

1

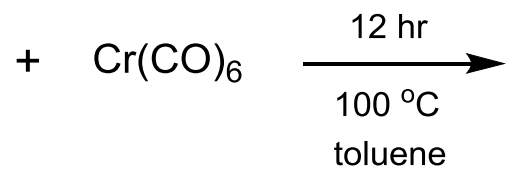

$1-\operatorname{Cr}(\mathrm{CO})_{4}$

N-(diphenylphosphino)-N-(1-methylethyl)-P,P-diphenyl-phosphinous amide (PNP ligand 1, 0.9500 g, 2.22 $\mathrm{mmol})$ and $\mathrm{Cr}(\mathrm{CO})_{6}(0.9781 \mathrm{~g}, 4.44 \mathrm{mmol})$ were combined in toluene $(8 \mathrm{~mL})$. The reaction mixture was heated at $100{ }^{\circ} \mathrm{C}$ for 12 hours. During the course of the reaction, unreacted $\mathrm{Cr}(\mathrm{CO})_{6}$ sublimed to the top of the vial and the vial was shaken every few hours to return the $\mathrm{Cr}(\mathrm{CO})_{6}$ back into the reaction solution. The solution was filtered hot using a syringe filter. Within minutes highly crystalline yellow solid formed. After $3 \mathrm{hr}$ at room temperature, the vial with yellow product was placed into a freezer $\left(-30{ }^{\circ} \mathrm{C}\right)$ overnight. The product was collected on a frit, washed with hexane $(2 \times 5 \mathrm{~mL})$, and dried under reduced pressure. To remove any possible residual $\mathrm{Cr}(\mathrm{CO})_{6}$, the yellow solid was heated at $120{ }^{\circ} \mathrm{C}$ overnight under reduced pressure to give $0.9476 \mathrm{~g}$ of product. Yield $72.1 \%$. ${ }^{1} \mathrm{H} \mathrm{NMR}\left(400 \mathrm{MHz}, \mathrm{CDCl}_{3}\right) \delta 7.76$ (tdd, $J=7.1,4.7$, $3.0 \mathrm{~Hz}, 8 \mathrm{H}), 7.50-7.44$ (m, 12H), 3.59 (tp, $J=13.8,6.9 \mathrm{~Hz}, 1 \mathrm{H}), 0.69$ (d, $J=6.8 \mathrm{~Hz}, 6 \mathrm{H}) .{ }^{31} \mathrm{P}$ NMR $(162$ $\left.\mathrm{MHz}, \mathrm{CDCl}_{3}\right) \delta$ 112.64. Elemental analysis for $\mathrm{C}_{31} \mathrm{H}_{27} \mathrm{CrNO}_{4} \mathrm{P}_{2}$ : Calculated: $\mathrm{C}, 62.95 ; \mathrm{H}, 4.60 ; \mathrm{N}, 2.37$ Found: C, 62.66; H, 4.72; N, 2.24 


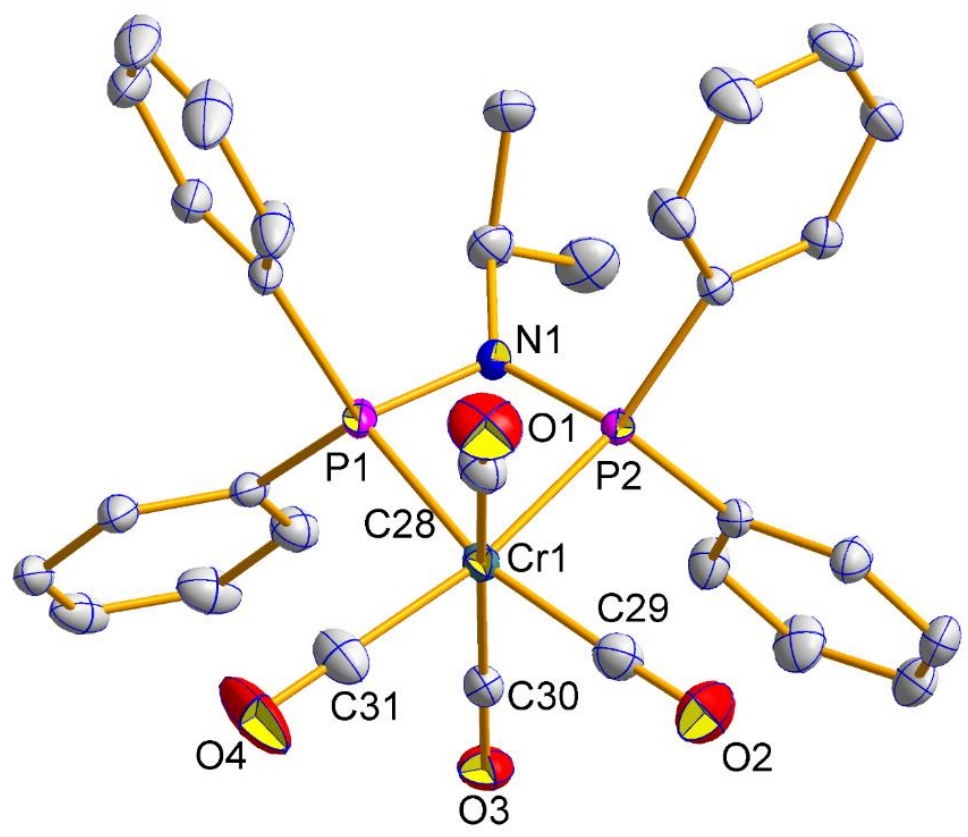

Figure S28. Molecular structure of $i$-Pr-PNP-Cr(CO) $)_{4}\left(\mathbf{1}-\mathbf{C r}(\mathbf{C O})_{4}\right)$. Thermal ellipsoids are shown at $50 \%$ probability and hydrogen atoms were omitted for clarity. Accession code: CCDC 1958685. 
Figure S29. ${ }^{1} \mathrm{H}$ and ${ }^{31} \mathrm{P}$ NMR spectra of $i$-Pr-PNP-Cr$(\mathrm{CO})_{4}\left(\mathbf{1 - C r}(\mathbf{C O})_{4}\right)$ in $\mathrm{CDCl}_{3}$.
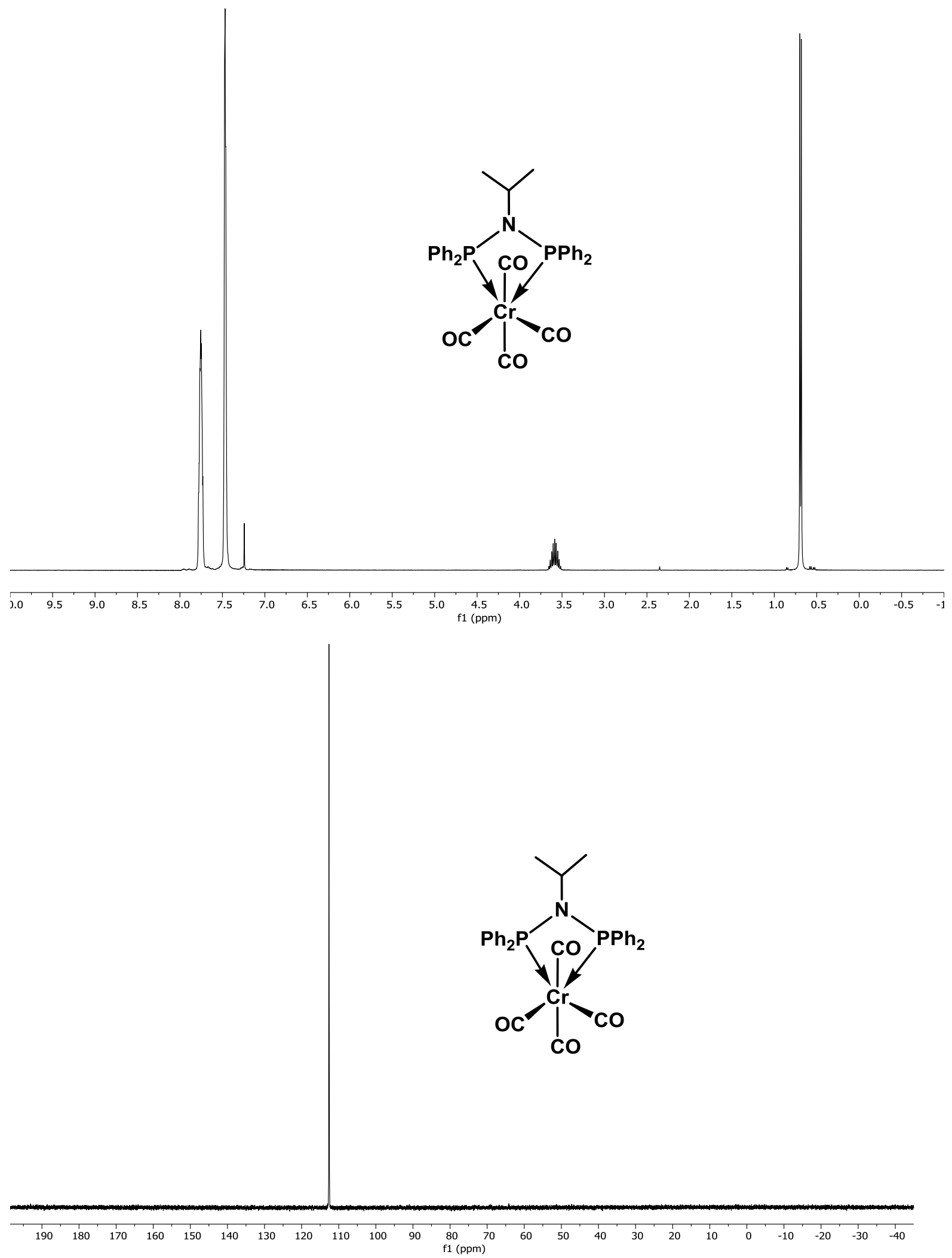


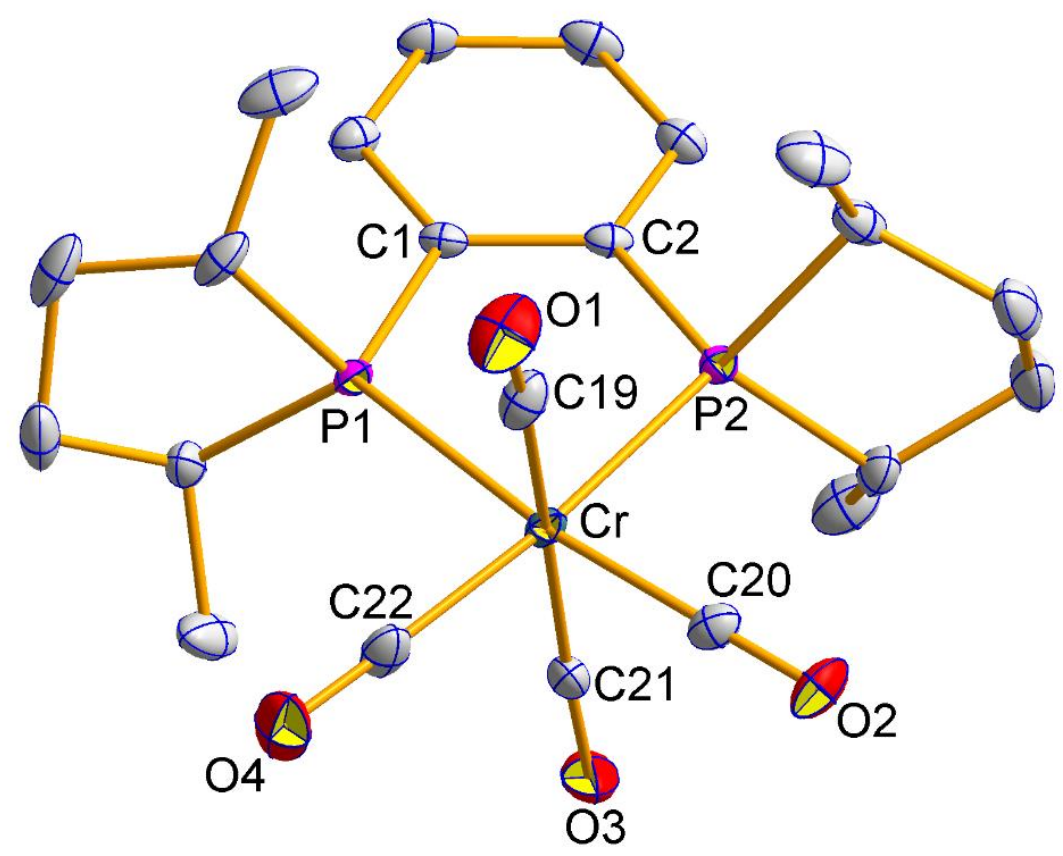

Figure S30. Molecular structure of $(S, S)$-MeDuPhos- $\mathrm{Cr}(\mathrm{CO})_{4}\left(\mathbf{1 0 -} \mathbf{C r}(\mathbf{C O})_{4}\right)$. Thermal ellipsoids are shown at $50 \%$ probability and hydrogen atoms were omitted for clarity. Accession code: CCDC 1958682. 
Figure S31. ${ }^{1} \mathrm{H}$ and ${ }^{13} \mathrm{C}$ NMR spectra of $(S, S)-\mathrm{MeDuPhos}-\mathrm{Cr}(\mathrm{CO})_{4}\left(\mathbf{1 0 -} \mathbf{C r}(\mathbf{C O})_{4}\right)$ in $\mathrm{CDCl}_{3}$.
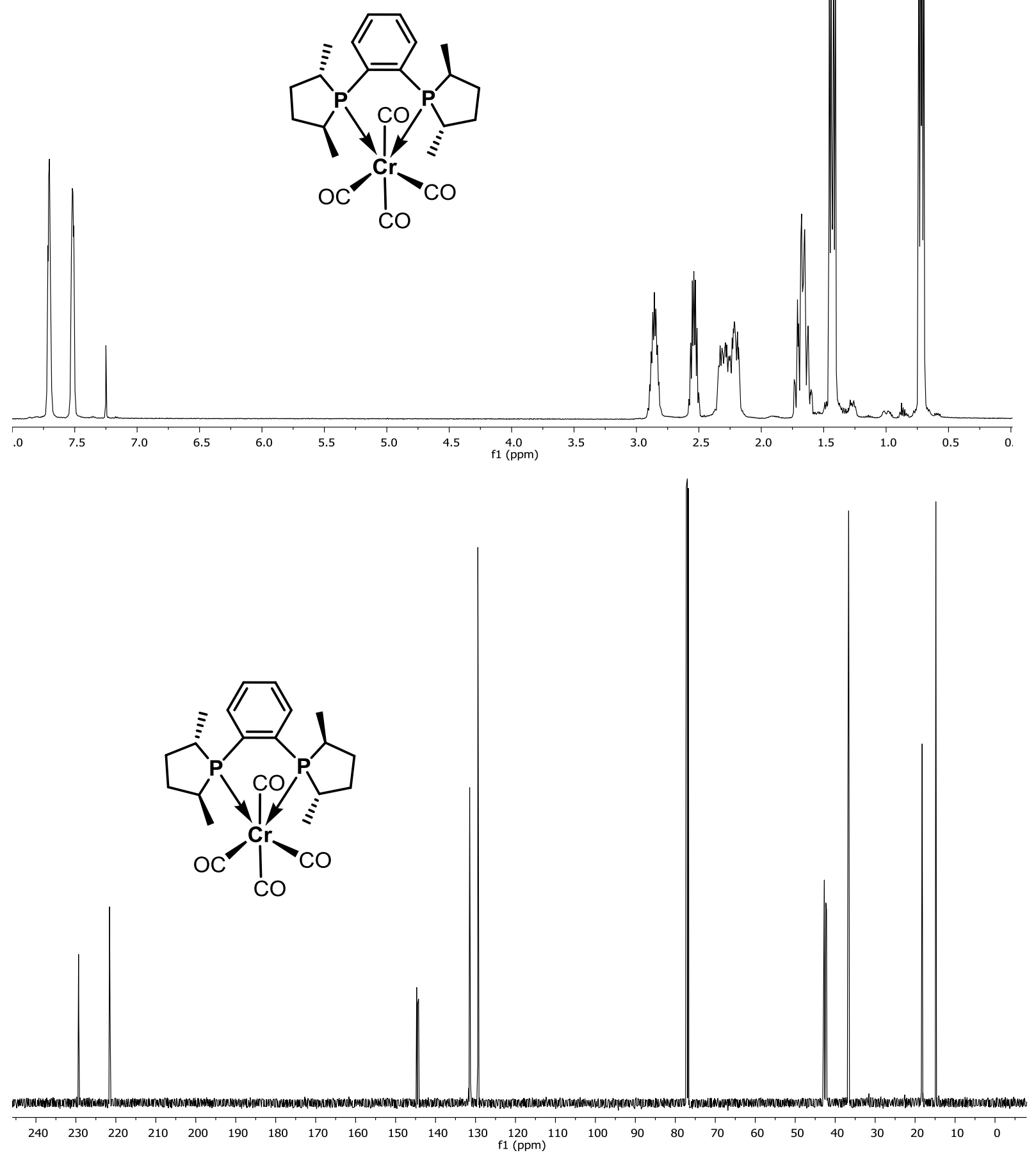
Figure S32. ${ }^{31} \mathrm{P}$ NMR spectrum of $(S, S)-\mathrm{MeDuPhos}-\mathrm{Cr}(\mathrm{CO})_{4}\left(\mathbf{1 0 -} \mathbf{C r}(\mathbf{C O})_{4}\right)$ in $\mathrm{CDCl}_{3}$.

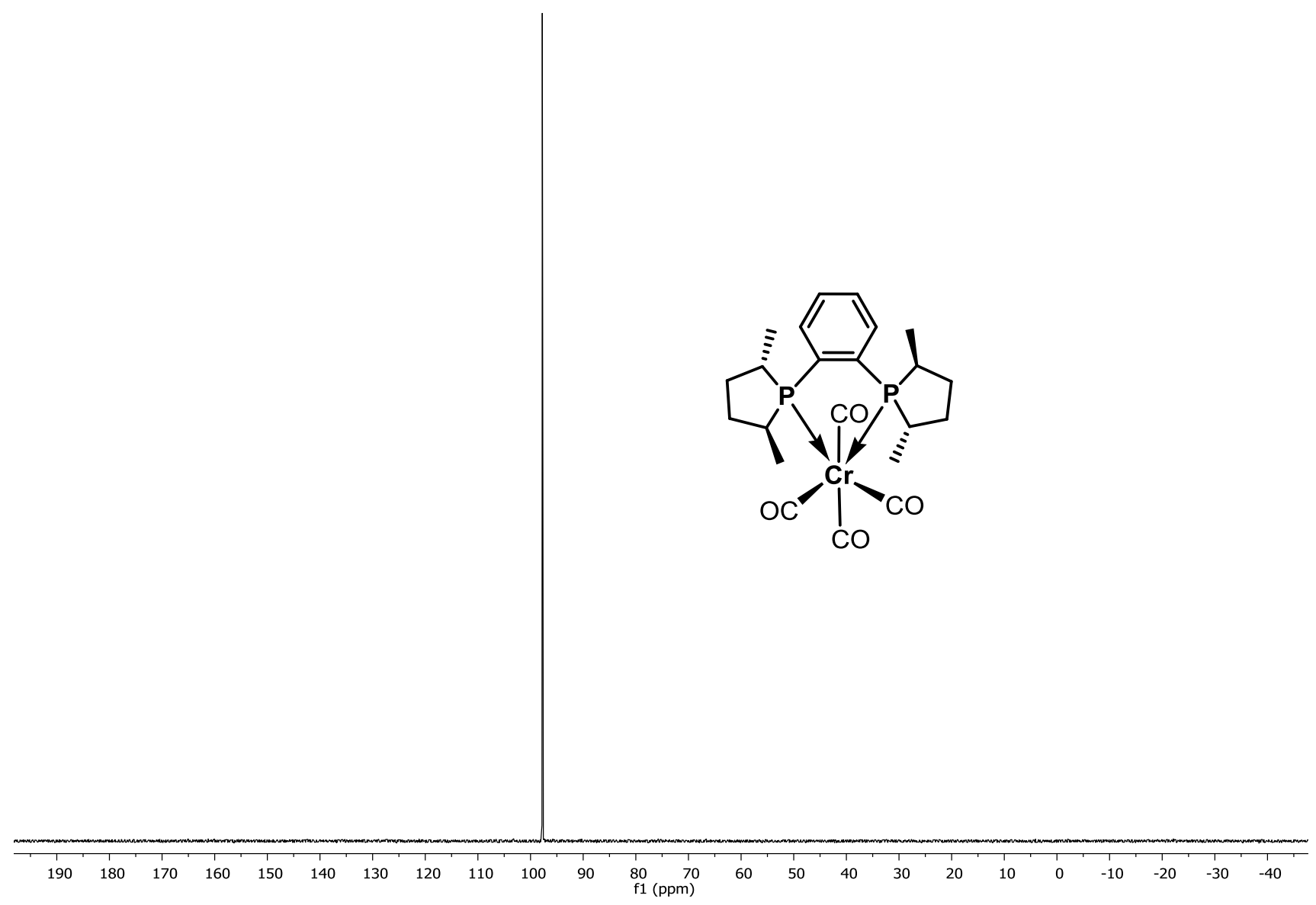




\section{Synthesis of 6-Cr(CO) $)_{4}$.}
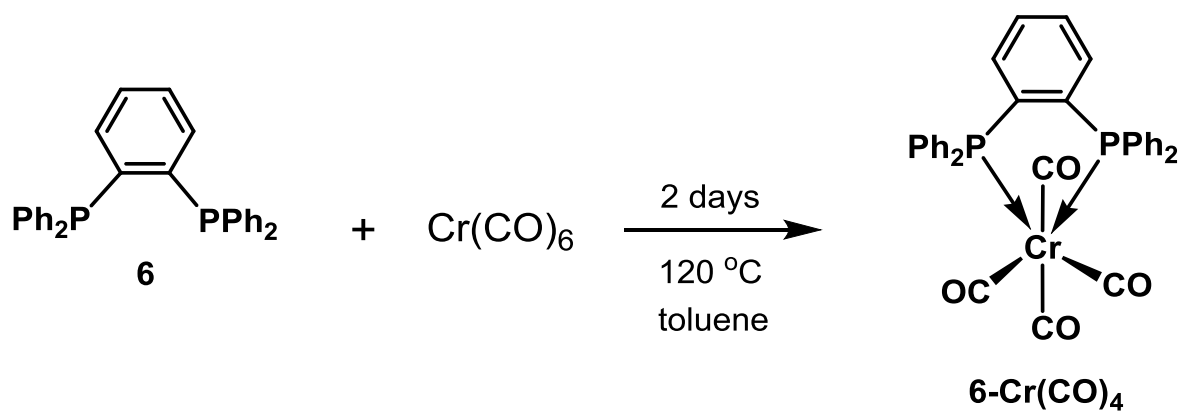

Ligand $6(1.070 \mathrm{~g}, 2.4 \mathrm{mmol})$ and $\mathrm{Cr}(\mathrm{CO})_{6}(1.055 \mathrm{~g}, 4.8 \mathrm{mmol})$ were combined with $8 \mathrm{~mL}$ of toluene in a 20 -mL vial equipped with a stir bar. After heating for about $2 \mathrm{hr}$ at $120^{\circ} \mathrm{C}$, off-white solid appeared. After heating for 2 days, the reaction mixture was cooled to room temperature. Off-white product (powder) was collected on the frit, washed with $3 \mathrm{~mL}$ of toluene and $5 \mathrm{~mL}$ of hexane, and dried under reduced pressure at $120{ }^{\circ} \mathrm{C}$ overnight. Obtained 1.234 g. Yield 84\%. Single crystals were grown for X-ray diffraction analysis: About $20 \mathrm{mg}$ of product was mixed with $3 \mathrm{~mL}$ of $\mathrm{C}_{6} \mathrm{D}_{6}$ giving a suspension. This suspension was heated for $2 \mathrm{hr}$ at $120{ }^{\circ} \mathrm{C}$. The suspension was filtered and the solution was put aside at room temperature for 3 days resulting in the formation of very small crystals that were suitable for X-ray analysis. Due to the insolubility of the complex in common NMR solvents, NMR spectroscopy is not reported for this complex. Elemental analysis for $\mathrm{C}_{34} \mathrm{H}_{24} \mathrm{CrNO}_{4} \mathrm{P}_{2}$ : Calculated: $\mathrm{C}, 66.89 ; \mathrm{H}, 3.96$. Found: $\mathrm{C}, 64.25 ; \mathrm{H}, 4.04$.

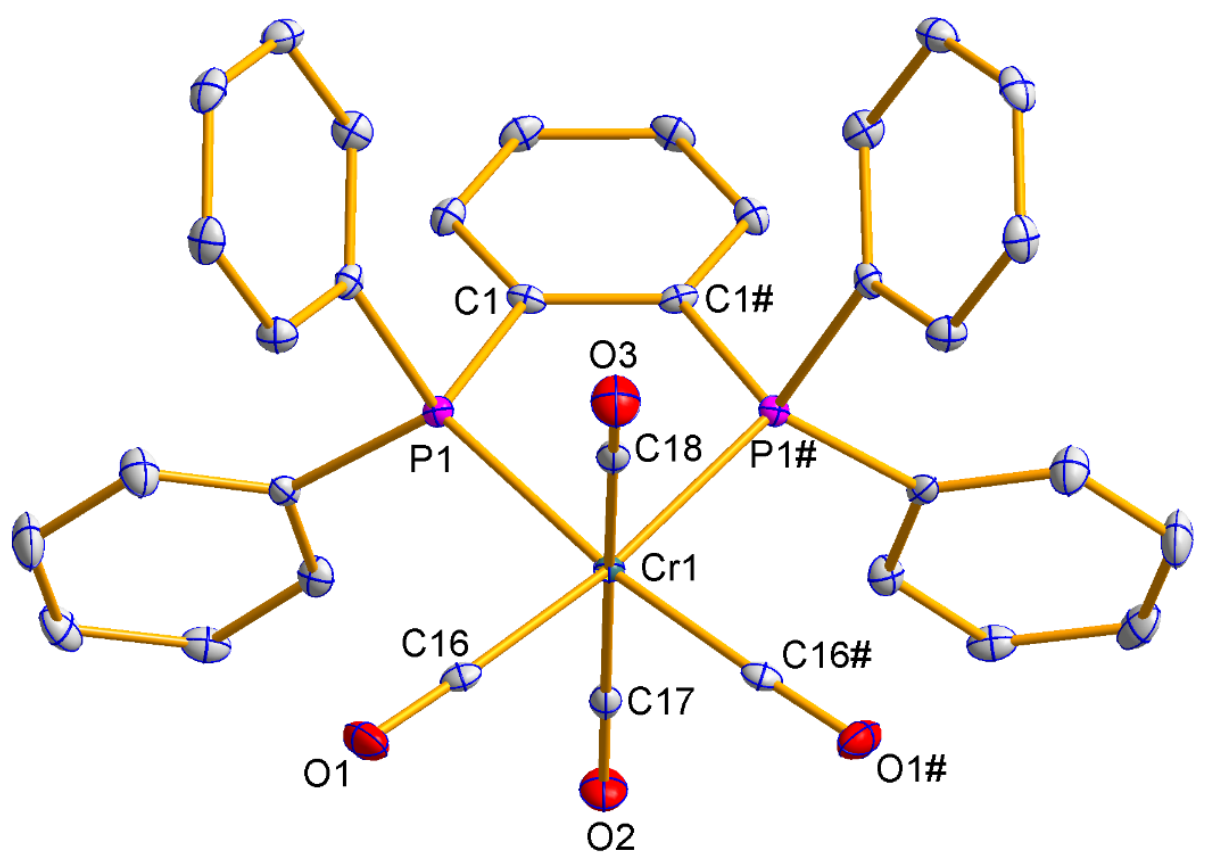

Figure S33. Molecular structure of $\mathrm{C}_{6} \mathrm{H}_{4}\left(\mathrm{PPh}_{2}\right)_{2}-\mathrm{Cr}(\mathrm{CO})_{4}\left(\mathbf{6}-\mathbf{C r}-(\mathbf{C O})_{4}\right)$. Thermal ellipsoids are shown at $50 \%$ probability and hydrogen atoms were omitted for clarity. C1\#, P1\#, C16\#, and O1\# are related through crystallographic symmetry to C1, P1, C16, and O1, respectively. Accession code: CCDC 1958676. 


\section{Competition Experiments}

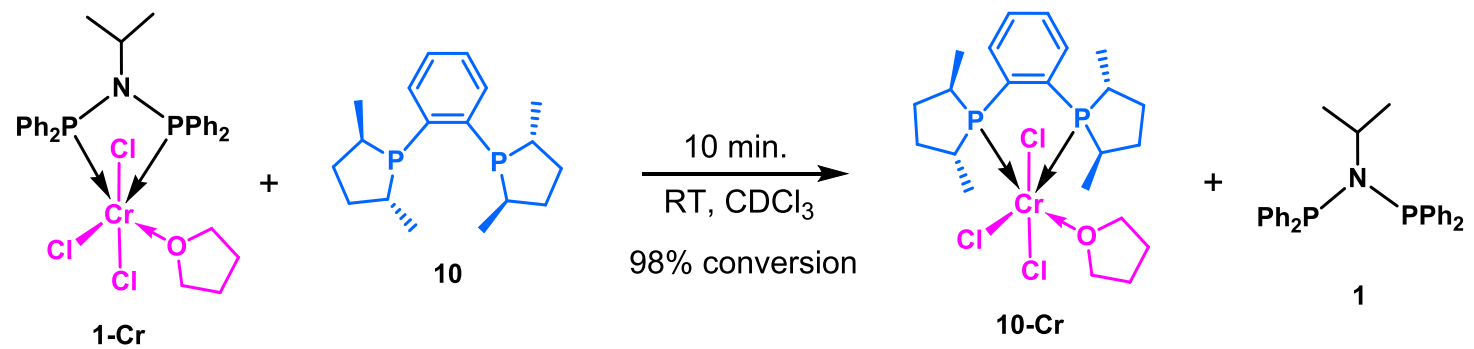

${ }^{1} \mathrm{H}$ and ${ }^{31} \mathrm{P}$ NMR spectra were taken of a solution of $\mathrm{N}, \mathrm{N}-\mathrm{bis}($ diphenylphosphino)-isopropylamine chromium trichloride THF adduct $(0.0500 \mathrm{~g}, 0.076 \mathrm{mmol})$ in $\mathrm{CDCl}_{3}(0.80 \mathrm{~mL})$. A sealed glass capillary tube containing an internal standard (tris(4-trifluoromethylphenyl)phosphine oxide) was added the the NMR tube and NMR spectra were recorded. MeDuPhos 10 (1,2-bis((2S,5S)-2,5-dimethylphospholan-1yl)benzene) (0.0233 g, $0.076 \mathrm{mmol}$ ) was added. NMR spectra taken within 10 minutes showed the N,Nbis(diphenylphosphino)-isopropylamine ligand 1 to MeDuPhos ligand $\mathbf{1 0}$ ratio as 45:1, indicating that nearly complete exchange had occurred.

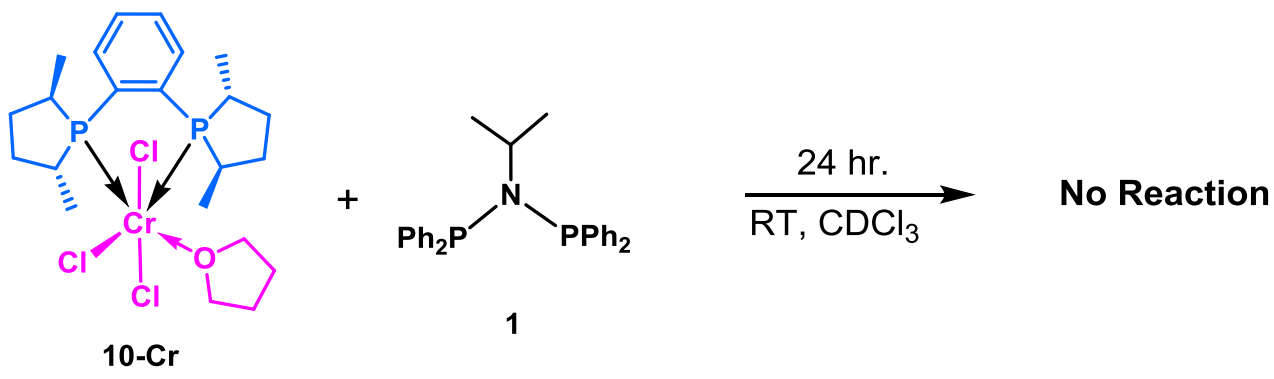

${ }^{1} \mathrm{H}$ and ${ }^{31} \mathrm{P}$ NMR spectra were taken of a solution of (1,3-bis((2S,5S)-2,5-dimethylphospholan-1yl)benzene) chromium trichloride THF adduct $(0.0500 \mathrm{~g}, 0.0931 \mathrm{mmol})$ in $\mathrm{CDCl}_{3}(0.80 \mathrm{~mL})$. The NMR tube also contained a capillary containing an internal standard (tris(4-trifluoromethylphenyl)phosphine oxide). The solution in the NMR tube was poured into a vial containing N,Nbis(diphenylphosphino)isopropylamine $(0.0398 \mathrm{~g}, 0.0931 \mathrm{mmol})$, the reactants were mixed, and NMR spectra were recorded after about 5 minutes. No DuPhos was apparent in the spectrum, while a large peak due to PNP was present. Spectra were taken the next day as well, showing no exchange had occurred. 
Figure S34. Competition reactions. No reaction occurred when the iPr-PNP ligand (1) was added to a solution of $\mathrm{MeDuPhos}-\mathrm{CrCl}_{3}(\mathrm{THF})(\mathbf{1 0 - C r})$ (spectra 1 and 2). Addition of the MeDuPhos ligand (10) to a solution of iPr-PNP-CrCl $3(\mathrm{THF})(\mathbf{1 - C r})$ led to the complexation of the MeDuPhos ligand (10) and the release of the iPr-PNP ligand (1) (spectra 3 and 4).

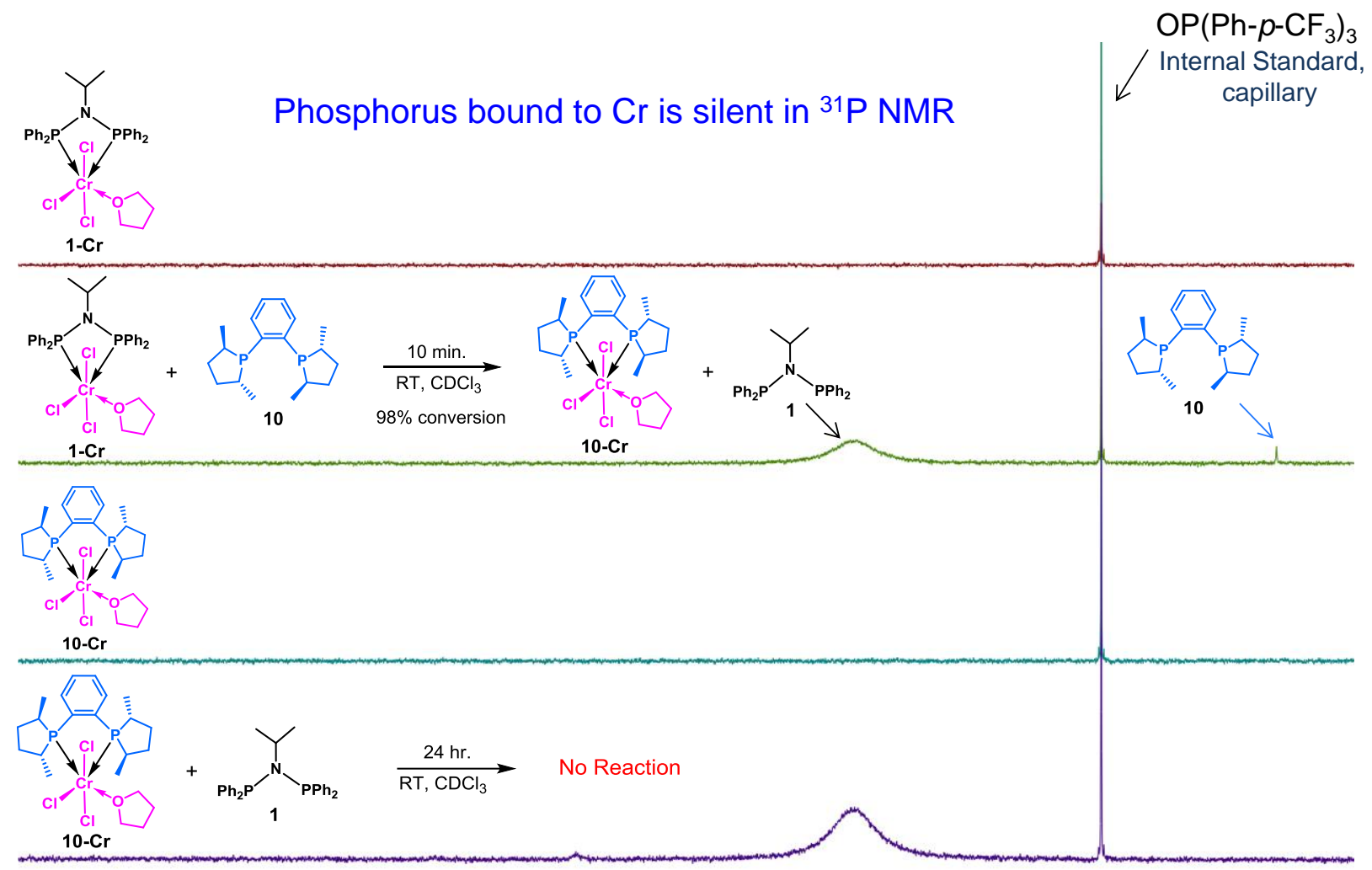

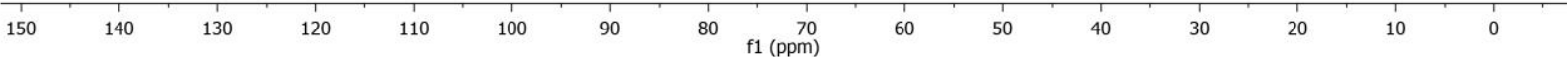




\section{Powder X-ray Diffraction Experimental Information}

The powdered samples were loaded into an acrylic sample holder in a glove box. An acrylic dome, with a small piece of lead foil attached to the interior to reduce scattered X-rays, was attached to each sample holder to maintain an inert atmosphere. A Bruker D8 Advance $\theta-\theta$ X-ray diffractometer equipped with a copper sealed-source tube and Vantec-1 linear position-sensitive detector was used to collect diffraction patterns. The tube was operated at $35 \mathrm{kV}$ and $45 \mathrm{~mA}$ and the samples were illuminated with copper $\mathrm{K}_{\alpha}$ radiation $(\lambda=1.541 \AA)$. XRD data were collected with a $3^{\circ}$ detector window from $6^{\circ}$ to $50^{\circ} 2 \theta$, with a step size of $0.026^{\circ}$ and $4 \mathrm{~s} /$ step collection times. Analysis of the resulting X-ray diffraction patterns was performed using JADE X-ray diffraction analysis software.

\section{Powder X-ray Diffraction Experimental Description}

The powder X-ray diffraction (PXRD) pattern of $(S, S)$-MeDuPhos- $\mathrm{CrCl}_{3}(\mathrm{THF})$ was acquired and compared with that of a spectrum calculated from the single crystal X-ray diffraction structure (Figure S35). Good agreement between the calculated and experimental pattern was observed. The experimentally obtained PXRD pattern of $(S, S)$-MeDuPhos- $\mathrm{CrCl}_{3}(\mathrm{THF})$ was compared to a PXRD spectrum of a sample of $(S, S)-\mathrm{MeDuPhos}-\mathrm{CrCl}_{3}(\mathrm{THF})$ to which $10 \mathrm{wt} \%$ of $\mathrm{CrCl}_{3}(\mathrm{THF})_{3}$ had been added (Figure S36). The purpose of this experiment was to evaluate whether the impurity could be detected in the PXRD spectrum. Unfortunately, very little difference between experimental patterns was observed. The impurity could not be detected without knowing its identity (Figure S37). If the impurity is known, it could potentially be detected at lower levels than $10 \mathrm{wt} \%$; additional work would be necessary to identify the lower threshold for detecting known impurities. Finally, the PXRD pattern of $(S, S)$-MeDuPhos-CrCl 3 (THF) was compared to that of $(\mathrm{S}, \mathrm{S})$-EtDuPhos-CrCl 3 (THF), and the differences between these patterns could be easily recognized (Figure S38). 
Figure S35. (S,S)-MeDuPhos-CrCl 3 (THF) (10-Cr) powder X-ray diffraction pattern: Experimental and calculated comparison: a) full scale; b) $9^{\circ}-20^{\circ}$ in $2 \theta$ (deg).

a) 12000

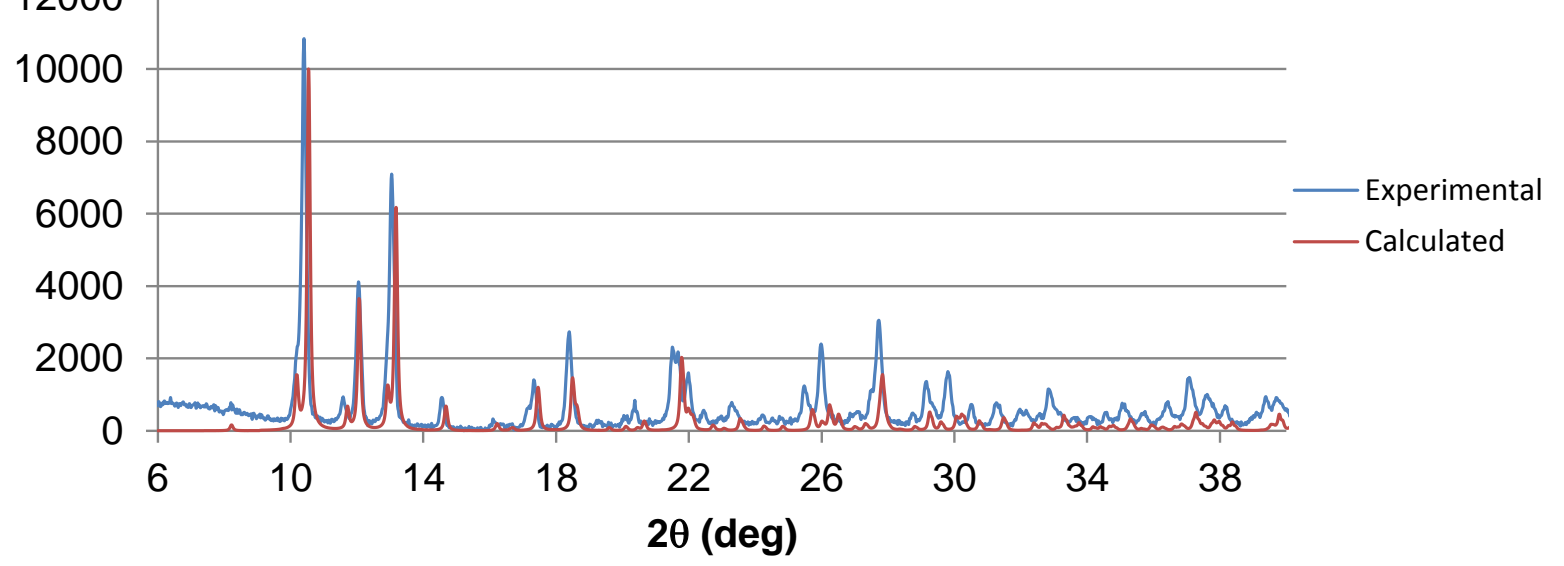

b) 12000

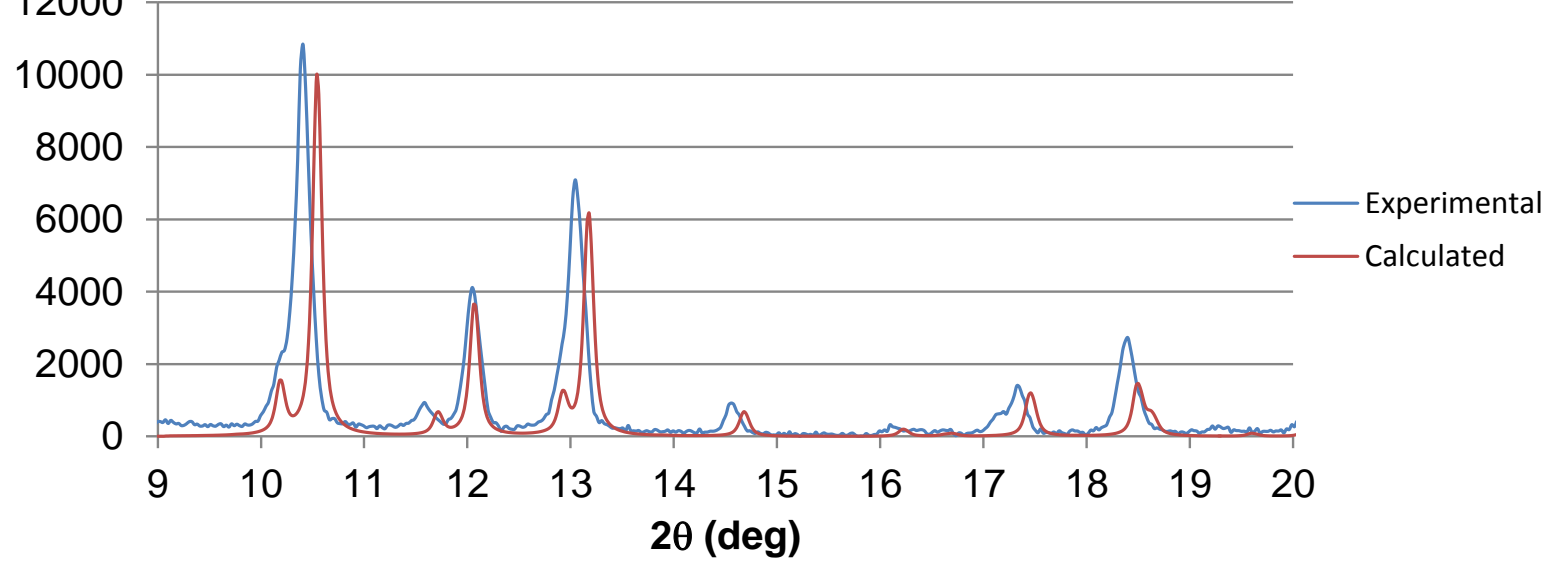


Figure S36. Comparison of powder X-ray diffraction patterns of $(S, S)-\mathrm{MeDuPhos}_{-} \mathrm{CrCl}_{3}(\mathrm{THF})(\mathbf{1 0 - C r})$ and $(S, S)-M e D u P h o s-\mathrm{CrCl}_{3}(\mathrm{THF})(\mathbf{1 0 - C r})+10 \mathrm{wt} \% \mathrm{CrCl}_{3}(\mathrm{THF})_{3}$ : a) full scale; b) $9^{\circ}-20^{\circ}$ in $2 \theta$ (deg).
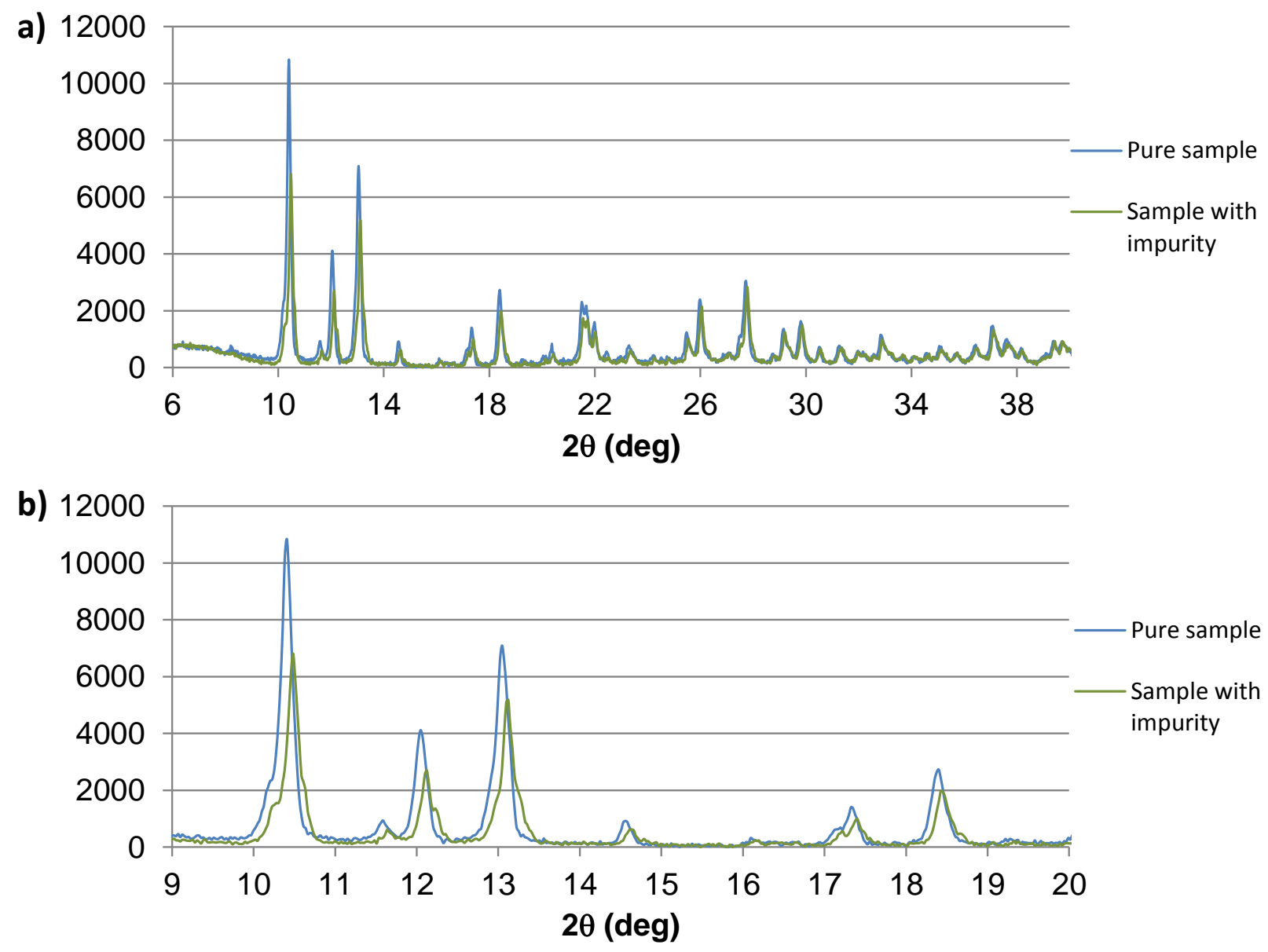
Figure S37. Comparison of experimental powder X-ray diffraction patterns of $(S, S)$-MeDuPhos$\mathrm{CrCl}_{3}$ (THF) (10-Cr), $(S, S)-\mathrm{MeDuPhos}-\mathrm{CrCl}_{3}(\mathrm{THF})(\mathbf{1 0}-\mathbf{C r})+10 \mathrm{wt} \%$ of $\mathrm{CrCl}_{3}(\mathrm{THF})_{3}$ impurity, and the calculated powder X-ray diffraction pattern of $\mathrm{CrCl}_{3}(\mathrm{THF})_{3}$

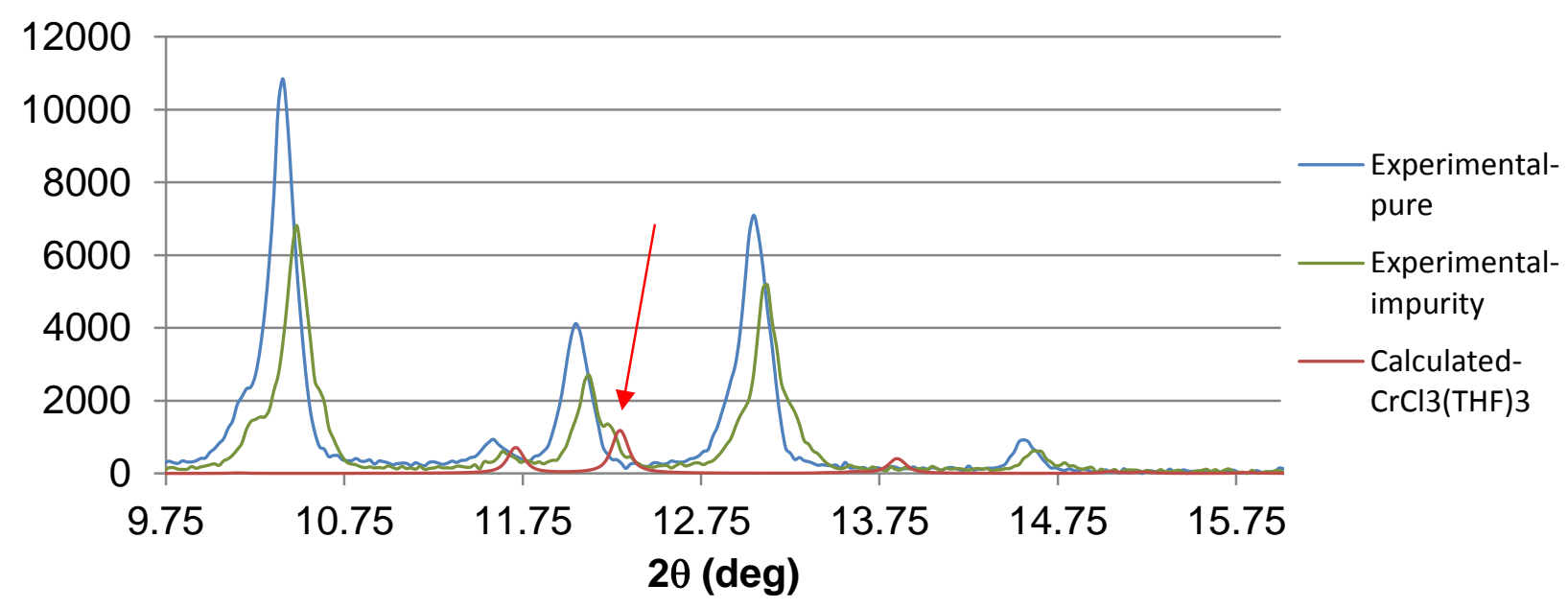

The red arrow points to a particularly noticeable shoulder in the experimental PXRD pattern of the S,SMeDuPhos- $\mathrm{CrCl}_{3}$ (THF) complex with the $10 \mathrm{wt} \% \mathrm{CrCl}_{3}(\mathrm{THF})_{3}$ impurity. 
Figure S38. Comparison of experimental powder X-ray diffraction patterns of $(S, S)$-MeDuPhos$\mathrm{CrCl}_{3}(\mathrm{THF})(\mathbf{1 0 - C r})$ and $(R, R)-\mathrm{EtDuPhos}-\mathrm{CrCl}_{3}(\mathrm{THF})(\mathbf{1 1 - C r})$.

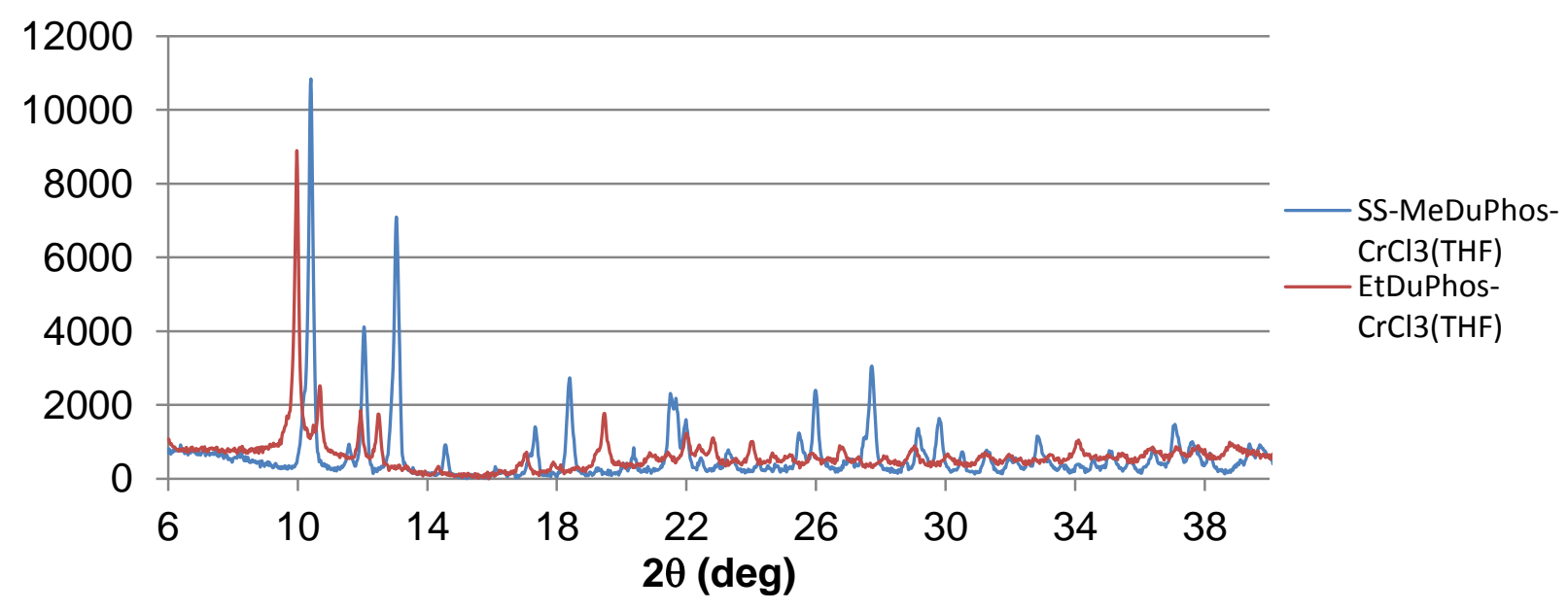




\section{IR Spectroscopy}

ATR-IR experiments were performed on a Perkin Elmer Frontier FT-IR spectrometer fitted with a Universal ATR Sampling Accessory. Between 8 and 32 scans were collected at ambient temperature with a scan range of $4000-400 \mathrm{~cm}^{-1}$ and a resolution of $4 \mathrm{~cm}^{-1}$. Data was analyzed using Thermo Scientific "Omnic 8" software.

Figure S39. IR Spectrum of $1-\mathrm{Cr}(\mathrm{CO})_{4}$.

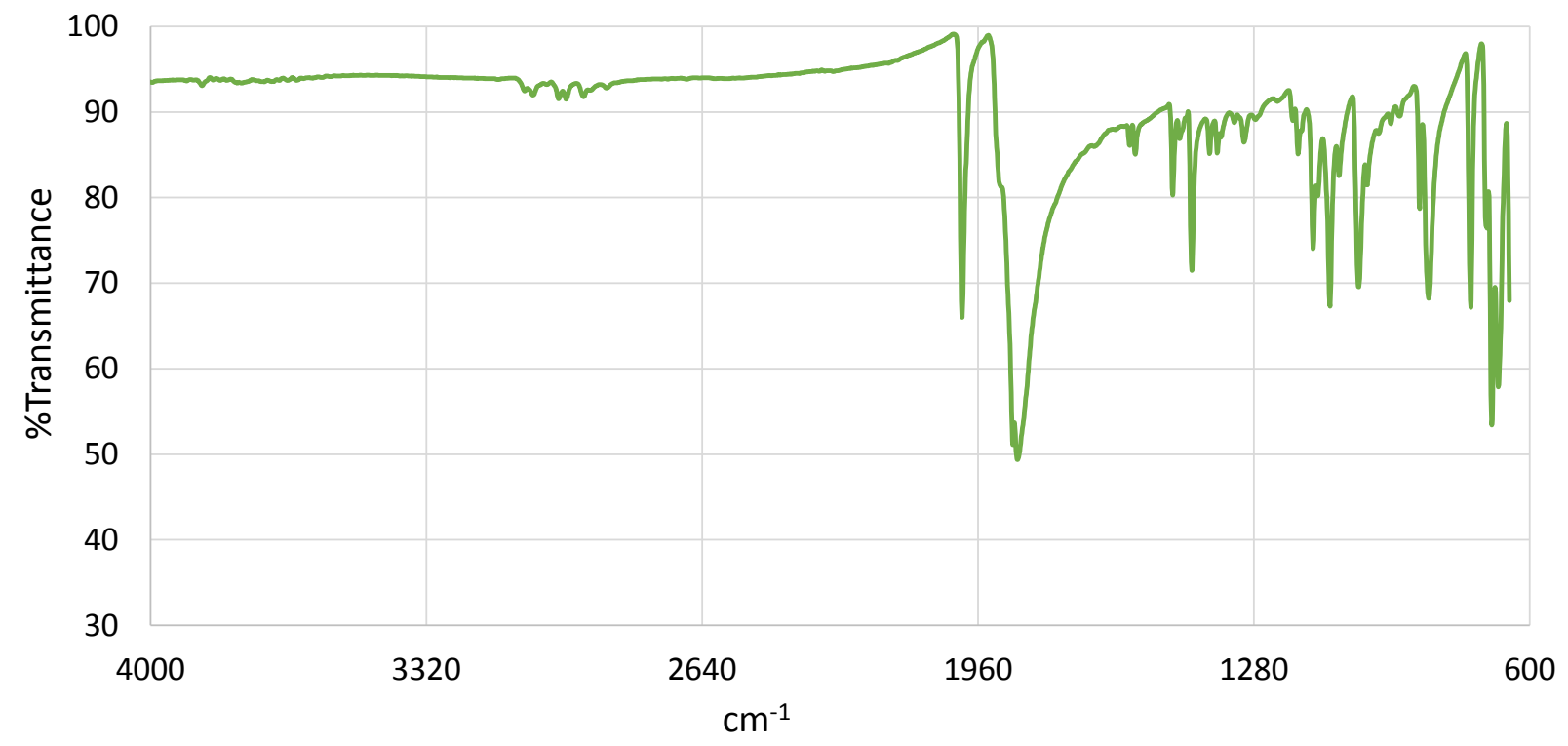

Figure S40. IR Spectrum of 6-Cr(CO) $)_{4}$.

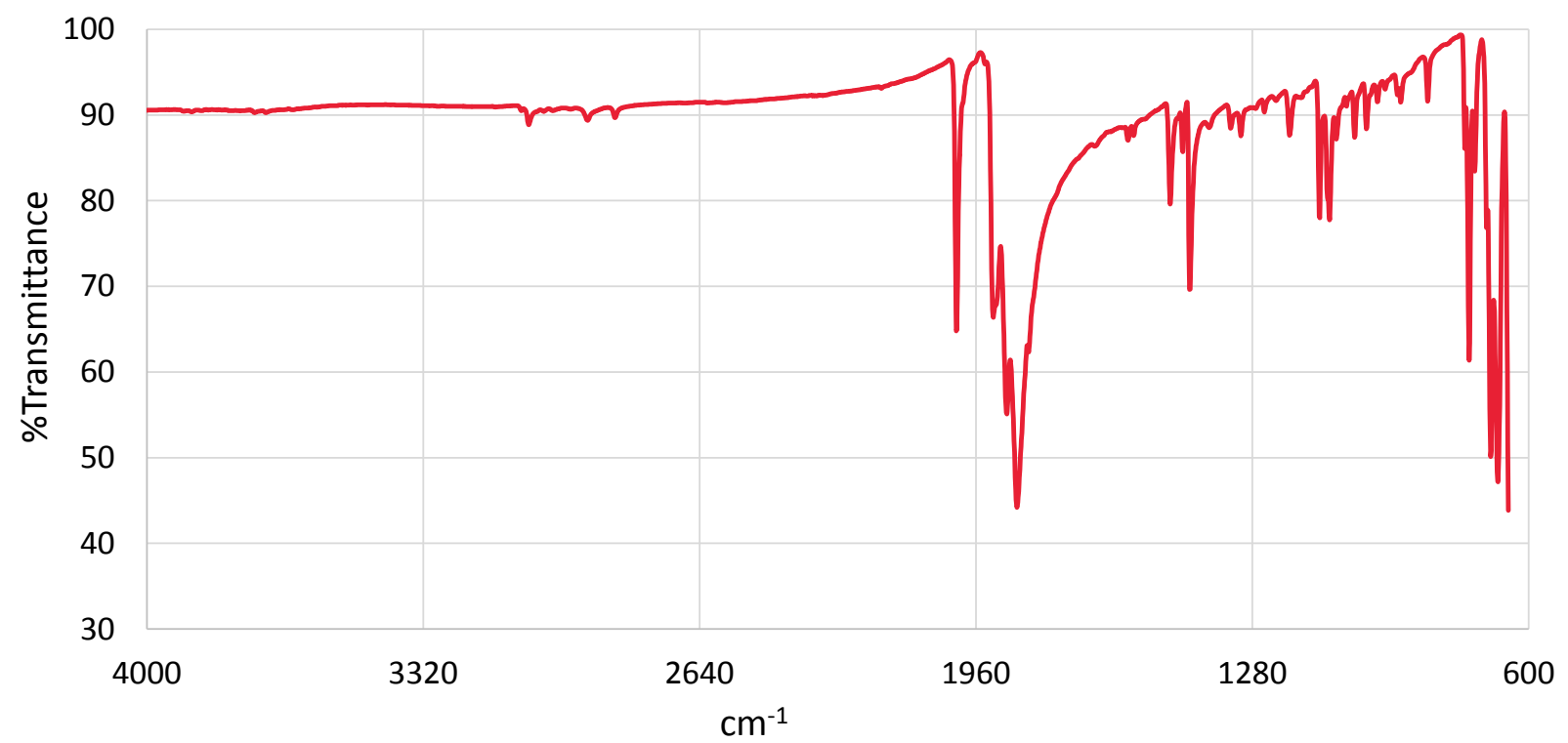


Figure S41. IR Spectrum of $10-\mathrm{Cr}(\mathrm{CO})_{4}$.

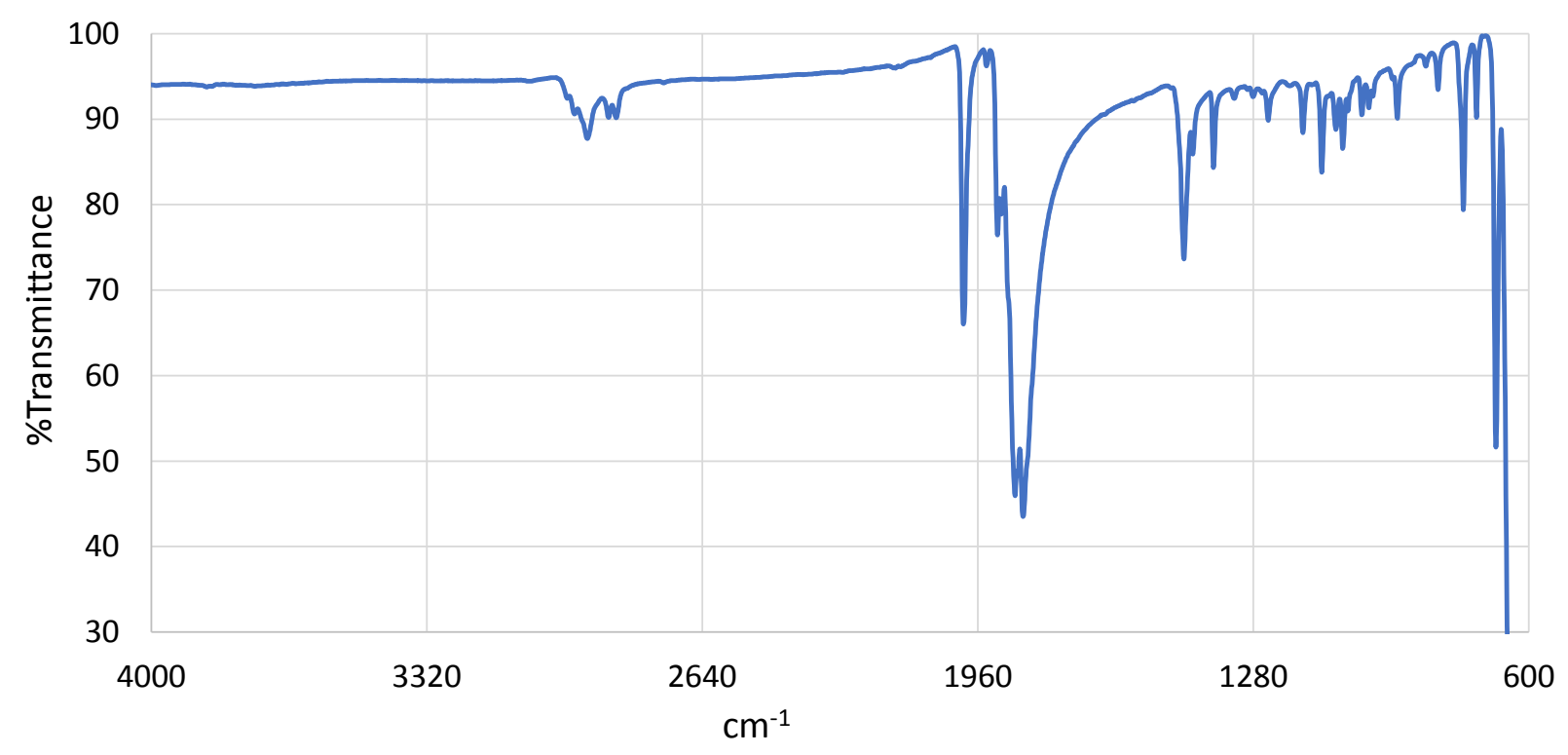

Figure S42. Overlay of IR spectra of $1-\operatorname{Cr}(\mathrm{CO})_{4}, 6-\operatorname{Cr}(\mathrm{CO})_{4}$, and $10-\mathrm{Cr}(\mathrm{CO})_{4}$ from 1400 to $2100 \mathrm{~cm}^{-1}$.

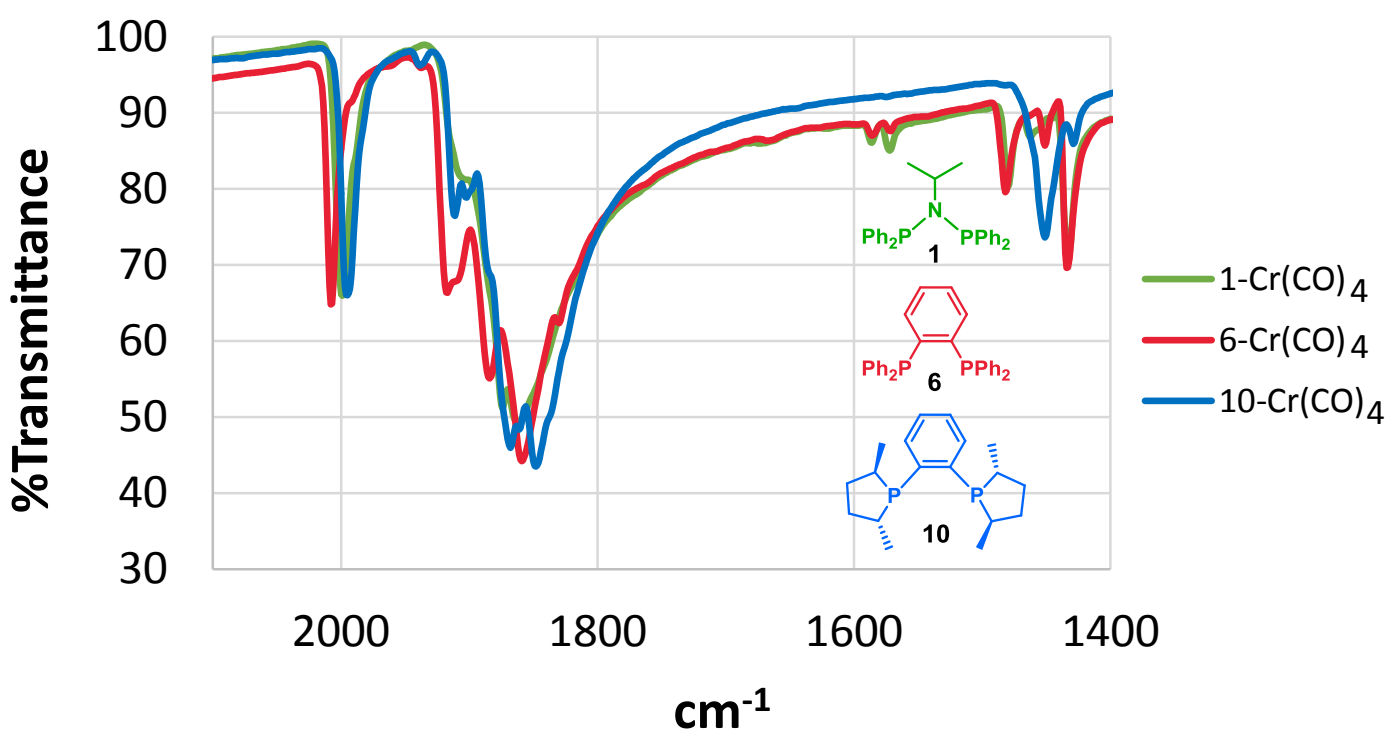




\section{Computational Steric Descriptor $\left(\% \mathbf{V}_{\text {bur }}\right)$}

Table 3. Schematic for calculation of the $\% \mathrm{~V}_{\text {bur }}$ descriptor.

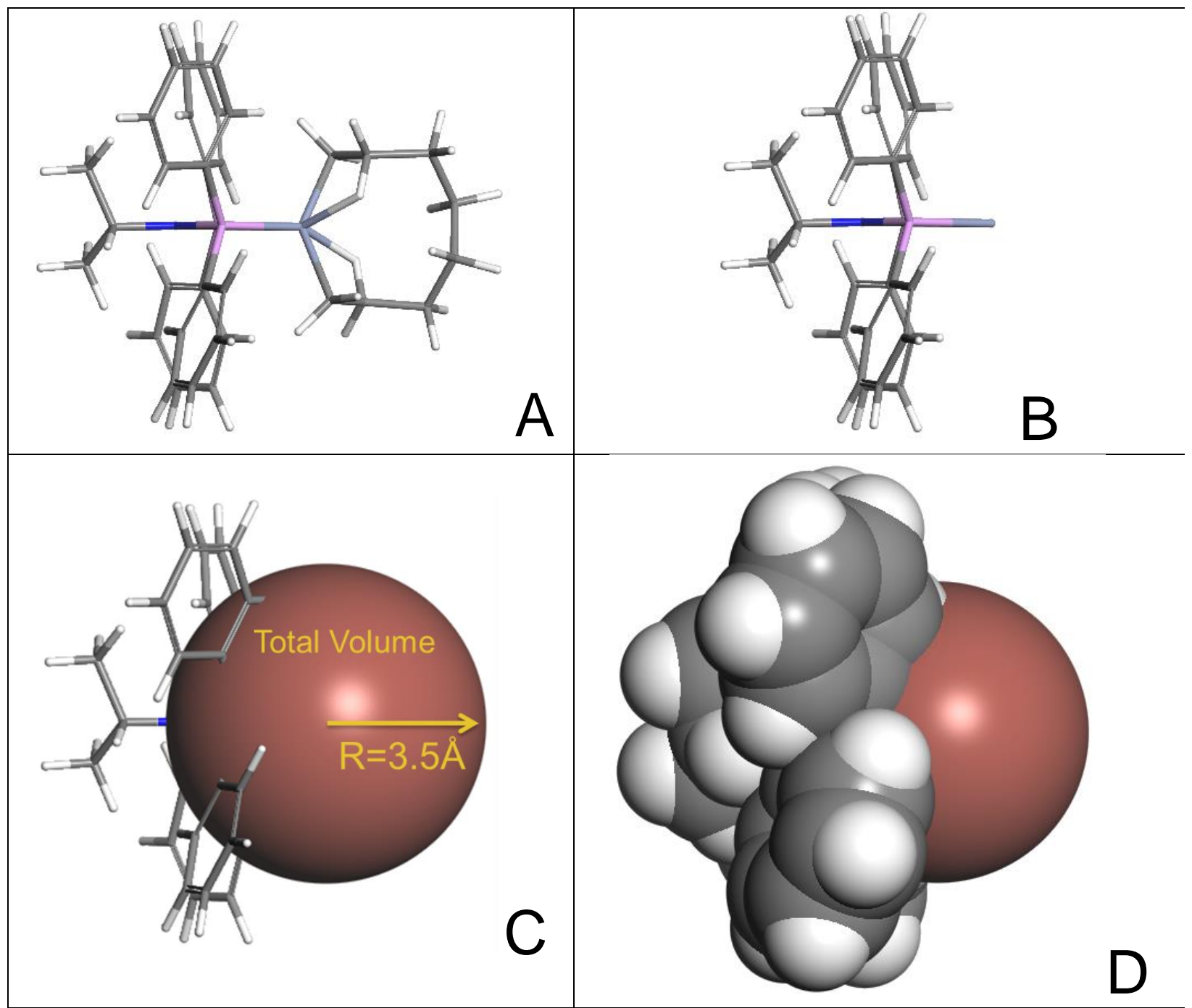

A geometry optimization on the chromacyclononane species was performed (Table 3a). Then the cycloalkenyl moiety is removed (Table $3 b$ ) and a sphere with a radius of $3.5 \AA$ is overlaid on this species with the $\mathrm{Cr}$ atom at the center of the sphere (Table 3c). Spheres with radii 1.17 times the van der Waal radii of the appropriate element were placed on each atom other than chromium (Table 3d). The volume of the $3.5 \AA$ sphere that is occluded by the other spheres is calculated. Finally, the $\% \mathrm{~V}_{\text {bur }}$ descriptor is calculated as the percent of the $3.5 \AA$ sphere that is occluded by the spheres on the ligand. This method is analogous to the $\% \mathrm{~V}_{\text {bur }}$ calculation performed by the SambVca program, but here we are starting with computationally derived species rather than crystal structures. 
Steric descriptors $\left(\% \mathrm{~V}_{\text {bur }}\right)$ were calculated for ligands 1, 3,9-17. Chromacyclononane derivatives were sketched in Materials Studio and optimized with the built-in cleaning forcefield. A set of trial conformers was generated for each molecule, and submitted to Gaussian $09^{2}$ for geometry optimization. Initial geometry optimizations in Gaussian were done with the B97-1 functional ${ }^{3}$ recommended by Wilson et al. ${ }^{4}$ together with a $6-31 \mathrm{G}^{* *}$ basis set using an electron configuration having three unpaired electrons for all molecules (unrestricted wavefunction). Based on these optimizations, the lowest-energy conformer for each molecule was selected for further geometry optimization implemented in $\mathrm{ORCA}^{5} 4.1$, using the TPSS density functional ${ }^{6}$ with D3BJ dispersion correction ${ }^{7}$ and a def2-TZVP basis set $^{8}$, as recommended for geometry optimization by Grimme in Chem. Eur. J. 2012, 18, 9955. The ORCA output was harvested into MaterialsStudio and output as an SD file for use in PipelinePilot 2018. A PipelinePilot protocol was used to process the SD file and produce an Excel file with accessible-volume descriptors.
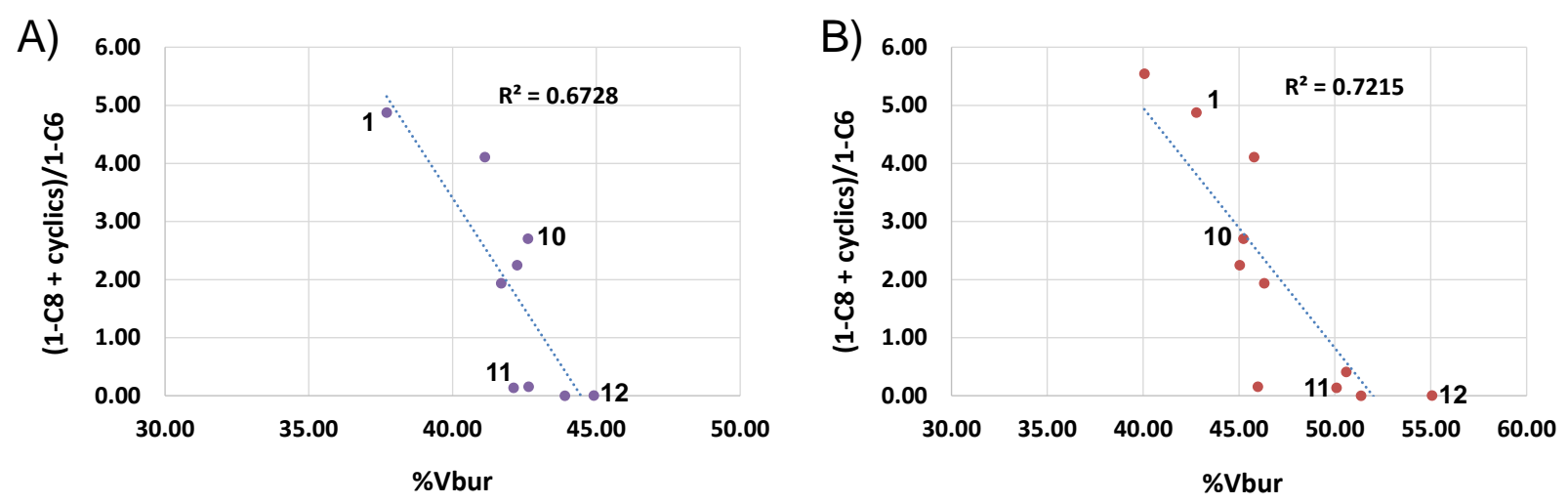

Figure S43. Correlation between $\% \mathrm{~V}_{\text {bur }}$ and experimental data (1-octene + cyclics)/1-hexene. A) $\% \mathrm{~V}_{\text {bur }}$ from SambVca using crystal structures. B) $\% \mathrm{~V}_{\text {bur }}$ from geometry optimized chromacyclononane species. 


\section{High-Throughput Ethylene Oligomerization Data}

Table S4. Averaged Activities of Chromium Catalysts Evaluated for Ethylene Oligomerization in the High-Throughput Reactor

\begin{tabular}{|c|c|c|c|c|c|c|c|c|c|c|}
\hline Entry & Compound & $\begin{array}{l}\text { 1-octene } \\
\text { activity } \\
\text { (g/g Cr hr) }\end{array}$ & $\begin{array}{l}\text { 1-hexene } \\
\text { activity } \\
\text { (g/g Cr hr) }\end{array}$ & $\begin{array}{c}\text { Methylcyclopentane } \\
\text { activity } \\
\text { (g/g Cr hr) }\end{array}$ & $\begin{array}{c}\text { Methylenecyclopentane } \\
\text { activity } \\
\text { (g/g Cr hr) }\end{array}$ & $\begin{array}{c}\text { Total cyclics } \\
\text { activity } \\
\text { (g/g Cr hr) }\end{array}$ & $\begin{array}{l}\text { Cyclics } \\
\text { ratio }^{\mathrm{a}}\end{array}$ & $\begin{array}{l}\mathrm{C} 10-\mathrm{C} 18^{\mathrm{b}} \\
\text { activity } \\
(\mathrm{g} / \mathrm{g} \mathrm{Cr} \mathrm{hr})\end{array}$ & $\begin{array}{c}\text { HDPE } \\
\text { activity } \\
\text { (g/g Cr hr) } \\
\end{array}$ & $\begin{array}{c}\text { Total } \\
\text { activity } \\
(\mathrm{g} / \mathrm{g} \mathrm{Cr} \mathrm{hr}) \\
\end{array}$ \\
\hline 1 & $2^{\mathrm{c}}$ & 315,788 & 69,827 & 11,019 & 11,750 & 22,769 & 1.07 & 40,155 & 8,962 & 457,501 \\
\hline 2 & 2-Cr & 295,574 & 87,565 & 9,590 & 12,010 & 21,600 & 1.25 & 38,490 & 16,231 & 459,459 \\
\hline 3 & $10^{c}$ & 40,904 & 12,106 & 2,933 & 10,163 & 13,096 & 3.47 & 2,773 & 6,308 & 75,187 \\
\hline 4 & 10-Cr & 322,928 & 157,999 & 22,910 & 79,324 & 102,233 & 3.46 & 31,989 & 7,442 & 622,592 \\
\hline 5 & $11^{\mathrm{c}}$ & 36,548 & 196,163 & 1,933 & 4,606 & 6,538 & 2.38 & 20,481 & 5,327 & 265,058 \\
\hline 6 & 11-Cr & 91,212 & 776,519 & 4,817 & 11,587 & 16,404 & 2.41 & 103,820 & 4,538 & 992,493 \\
\hline 7 & $12^{\mathrm{c}}$ & 962 & 702 & 19 & 87 & 106 & 4.50 & 62 & 6,885 & 8,715 \\
\hline 8 & 12-Cr & 1,154 & 214,048 & 67 & 144 & 212 & 2.14 & 3,722 & 4,577 & 223,713 \\
\hline 9 & $13^{\mathrm{c}}$ & 65,933 & 28,817 & 6,029 & 14,433 & 20,462 & 2.39 & 4,849 & 6,442 & 126,503 \\
\hline 10 & 13-Cr & 264,413 & 154,433 & 24,231 & 57,077 & 81,308 & 2.36 & 28,141 & 5,673 & 533,968 \\
\hline 11 & $14^{\mathrm{c}}$ & 4,808 & 20,846 & 221 & 413 & 635 & 1.87 & 1,407 & 6,212 & 33,907 \\
\hline 12 & 14-Cr & 67,548 & 494,510 & 3,538 & 6,394 & 9,933 & 1.81 & 50,970 & 5,538 & 628,499 \\
\hline 13 & $15^{\mathrm{c}}$ & 1,837 & 6,038 & 2,250 & 3,635 & 5,885 & 1.62 & 6,611 & 7,538 & 27,909 \\
\hline 14 & 15-Cr & 3,010 & 990 & 1,048 & 1,798 & 2,846 & 1.72 & 3,311 & 7,962 & 18,119 \\
\hline 15 & $9^{\mathrm{c}}$ & 68,596 & 91,385 & 12,317 & 23,615 & 35,933 & 1.92 & 28,917 & 5,385 & 230,215 \\
\hline 16 & 9-Cr & 71,635 & 51,663 & 9,673 & 18,885 & 28,558 & 1.95 & 21,867 & 4,673 & 178,396 \\
\hline 17 & $16^{\mathrm{c}}$ & 1,865 & 404 & 19 & 96 & 115 & 5.00 & 90 & 6,923 & 9,398 \\
\hline 18 & 16-Cr & 3,817 & 6,212 & 365 & 644 & 1,010 & 1.76 & 683 & 6,442 & 18,163 \\
\hline 19 & $17^{\mathrm{c}}$ & 41,394 & 192 & 19 & 96 & 115 & 5.00 & 491 & 5,885 & 48,077 \\
\hline 20 & 17-Cr & 144 & 161,404 & 19 & 96 & 115 & 5.00 & 1,980 & 4,519 & 168,163 \\
\hline
\end{tabular}

Cyclics ratio $=\frac{\text { methylenecyclopentane activity }}{\text { methylcyclopentane activity }}$

${ }^{\mathrm{b}} \mathrm{C} 10$ - C18: Higher $\alpha$-olefins include decenes, dodecenes, tetradecenes, hexadecenes, and octadecenes. GC retention times defined in Table S2 on pg. 4.

In situ catalyst formation with $\mathrm{CrCl}_{3}(\mathrm{THF})_{3}$.

${ }^{\mathrm{d}} 0.1 \mu \mathrm{mol}$ of $\mathrm{Cr}$, total volume $=5 \mathrm{~mL}$, solvent $=$ methylcyclohexane, MMAO-3A: $\mathrm{Cr}=1000: 1,45^{\circ} \mathrm{C}, 500$ psi ethylene, $30-\mathrm{minute}$ reaction time, values are averages of duplicates. 
Table S5. Averaged Selectivities of Chromium Catalysts Evaluated for Ethylene Oligomerization in the High-Throughput Reactor

\begin{tabular}{|c|c|c|c|c|c|c|c|c|c|}
\hline Entry & Compound & $\begin{array}{c}\text { 1-octene } \\
\text { selectivity } \\
(\mathrm{wt} \%) \\
\end{array}$ & $\begin{array}{c}\text { 1-hexene } \\
\text { selectivity } \\
\text { (wt\%) }\end{array}$ & $\begin{array}{l}\text { Methylcyclopentane } \\
\text { selectivity } \\
\text { (wt\%) } \\
\end{array}$ & $\begin{array}{c}\text { Methylenecyclopentane } \\
\text { selectivity } \\
\text { (wt } \%) \\
\end{array}$ & $\begin{array}{c}\text { Total cyclics } \\
\text { selectivity } \\
(\mathrm{wt} \%) \\
\end{array}$ & $\begin{array}{l}\mathrm{C} 10-\mathrm{C} 18^{\mathrm{a}} \\
\text { selectivity } \\
(\mathrm{wt} \%) \\
\end{array}$ & $\begin{array}{l}\text { HDPE } \\
\text { selectivity } \\
\text { (wt } \%) \\
\end{array}$ & $\begin{array}{c}\text { Total } \\
\text { selectivity } \\
\text { (wt } \%) \\
\end{array}$ \\
\hline 1 & $2^{\mathrm{b}}$ & 69.1 & 15.2 & 2.41 & 2.57 & 4.98 & 8.75 & 1.96 & 100.0 \\
\hline 2 & 2-Cr & 64.0 & 19.5 & 2.06 & 2.60 & 4.66 & 8.30 & 3.59 & 100.0 \\
\hline 3 & $10^{\mathrm{b}}$ & 54.4 & 16.1 & 3.91 & 13.5 & 17.4 & 3.71 & 8.37 & 100.0 \\
\hline 4 & 10-Cr & 52.0 & 25.3 & 3.68 & 12.8 & 16.4 & 5.14 & 1.19 & 100.0 \\
\hline 5 & $11^{\mathrm{b}}$ & 37.6 & 36.2 & 2.28 & 6.25 & 8.53 & 5.44 & 12.3 & 100.0 \\
\hline 6 & 11-Cr & 9.19 & 78.2 & 0.49 & 1.17 & 1.65 & 10.5 & 0.46 & 100.0 \\
\hline 7 & $12^{\mathrm{b}}$ & 10.9 & 8.02 & 0.22 & 0.99 & 1.22 & 0.71 & 79.2 & 100.0 \\
\hline 8 & 12-Cr & 0.52 & 95.7 & 0.03 & 0.06 & 0.09 & 1.66 & 2.04 & 100.0 \\
\hline 9 & $\mathbf{1 3}^{\mathrm{b}}$ & 52.1 & 22.8 & 4.77 & 11.4 & 16.2 & 3.83 & 5.14 & 100.0 \\
\hline 10 & 13-Cr & 49.6 & 28.8 & 4.55 & 10.7 & 15.3 & 5.26 & 1.07 & 100.0 \\
\hline 11 & $14^{\mathrm{b}}$ & 14.1 & 60.7 & 0.64 & 1.21 & 1.85 & 4.09 & 19.4 & 100.0 \\
\hline 12 & 14-Cr & 10.8 & 78.7 & 0.57 & 1.02 & 1.58 & 8.07 & 0.88 & 100.0 \\
\hline 13 & $15^{\mathrm{b}}$ & 21.7 & 6.60 & 8.08 & 13.1 & 21.1 & 23.7 & 26.9 & 100.0 \\
\hline 14 & 15-Cr & 16.6 & 5.47 & 5.79 & 9.92 & 15.7 & 18.3 & 43.9 & 100.0 \\
\hline 15 & $9^{\mathrm{b}}$ & 39.7 & 29.8 & 5.35 & 10.3 & 15.6 & 12.6 & 2.34 & 100.0 \\
\hline 16 & 9-Cr & 40.1 & 29.0 & 5.42 & 10.6 & 16.0 & 12.3 & 2.62 & 100.0 \\
\hline 17 & $16^{\mathrm{b}}$ & 4.28 & 19.8 & 0.20 & 1.02 & 1.22 & 0.96 & 73.8 & 100.0 \\
\hline 18 & 16-Cr & 21.1 & 34.5 & 2.02 & 3.56 & 5.59 & 3.79 & 35.0 & 100.0 \\
\hline 19 & $17^{\mathrm{b}}$ & 0.40 & 86.1 & 0.04 & 0.20 & 0.24 & 1.02 & 12.3 & 100.0 \\
\hline 20 & 17-Cr & 0.09 & 96.0 & 0.01 & 0.06 & 0.07 & 1.17 & 2.71 & 100.0 \\
\hline
\end{tabular}

${ }^{\mathrm{a}} \mathrm{C} 10$ - C18: Higher $\alpha$-olefins include decenes, dodecenes, tetradecenes, hexadecenes, and octadecenes. GC retention times in Table S2 on pg. 4. ${ }^{\mathrm{b}}$ In situ catalyst formation with $\mathrm{CrCl}_{3}(\mathrm{THF})_{3}$.

${ }^{\mathrm{c}} 0.1 \mu \mathrm{mol}$ of $\mathrm{Cr}$, total volume $=5 \mathrm{~mL}$, solvent $=$ methylcyclohexane, $\mathrm{MMAO}-3 \mathrm{~A}: \mathrm{Cr}=1000: 1,45^{\circ} \mathrm{C}, 500$ psi ethylene, 30-minute reaction time, values are averages of duplicates. 
Table S6. GC data for Chromium Catalysts Evaluated for Ethylene Oligomerization in the High-Throughput Reactor

\begin{tabular}{|c|c|c|c|c|c|c|c|c|c|c|}
\hline Entry & Compound & $\begin{array}{c}\text { 1-octene } \\
\text { (g/g nonane) }\end{array}$ & $\begin{array}{c}\text { 1-hexene } \\
\text { (g/g nonane) }\end{array}$ & $\begin{array}{c}\text { Methylcyclopentane } \\
\text { (g/g nonane) }\end{array}$ & $\begin{array}{c}\text { Methylenecyclopentane } \\
\text { (g/g nonane) }\end{array}$ & $\begin{array}{c}\mathrm{C} 10^{\mathrm{b}} \\
\text { (g/g nonane) }\end{array}$ & $\begin{array}{c}\mathrm{C} 12 \\
\text { (g/g nonane) } \\
\end{array}$ & $\begin{array}{c}\mathrm{C} 14 \\
\text { (g/g nonane) } \\
\end{array}$ & $\begin{array}{c}\mathrm{C} 16 \\
\text { (g/g nonane) } \\
\end{array}$ & $\begin{array}{c}\mathrm{C} 18 \\
\text { (g/g nonane) }\end{array}$ \\
\hline 1 & $2^{\mathrm{b}}$ & 14.879 & 3.098 & 0.519 & 0.556 & 0.41959 & 0.53321 & 0.55113 & 0.17674 & 0.12629 \\
\hline 2 & $2^{\mathrm{b}}$ & 17.963 & 4.164 & 0.627 & 0.666 & 0.53229 & 0.76641 & 0.74518 & 0.1885 & 0.13674 \\
\hline 3 & $2-\mathrm{Cr}$ & 12.53366 & 4.51964 & 0.38115 & 0.50774 & 0.45736 & 0.43874 & 0.42324 & 0.14661 & 0.11442 \\
\hline 4 & $2-\mathrm{Cr}$ & 18.20601 & 4.58715 & 0.61618 & 0.74131 & 0.58242 & 0.82174 & 0.72896 & 0.16352 & 0.12593 \\
\hline 5 & $\mathbf{1 0}^{\mathrm{b}}$ & 1.976 & 0.589 & 0.147 & 0.487 & 0.04206 & 0.03069 & 0.03298 & 0.03285 & 0.00651 \\
\hline 6 & $10^{b}$ & 2.278 & 0.67 & 0.158 & 0.57 & 0.04866 & 0.03693 & 0.03927 & 0.01126 & 0.00721 \\
\hline 7 & 10-Cr & 7.1559 & 15.93568 & 1.10783 & 3.89895 & 0.488 & 0.61094 & 0.3855 & 0.03993 & 0.02183 \\
\hline 8 & $10-\mathrm{Cr}$ & 9.27603 & 17.64879 & 1.27476 & 4.3507 & 0.58682 & 0.72282 & 0.40959 & 0.04143 & 0.02003 \\
\hline 9 & $11^{\mathrm{b}}$ & 9.101 & 1.776 & 0.093 & 0.225 & 0.72421 & 0.21154 & 0.04192 & 0.00213 & 0.00109 \\
\hline 10 & $11^{\mathrm{b}}$ & 11.3 & 2.025 & 0.108 & 0.254 & 0.85481 & 0.24365 & 0.04691 & 0.00232 & 0.00148 \\
\hline 11 & 11-Cr & 40.449 & 4.759 & 0.241 & 0.597 & 4.47183 & 0.8032 & 0.26663 & 0.00186 & 0.00000 \\
\hline 12 & 11-Cr & 40.309 & 4.727 & 0.26 & 0.608 & 4.20818 & 0.78862 & 0.25482 & 0.00217 & 0.00000 \\
\hline 13 & $\mathbf{1 2}^{\mathrm{b}}$ & 0.031 & 0.038 & 0.001 & 0.004 & 0.00193 & 0.00025 & 0.00025 & 0.00034 & 0.00000 \\
\hline 14 & $12^{\mathrm{b}}$ & 0.042 & 0.062 & 0.001 & 0.005 & 0.0021 & 0.00033 & 0.00038 & 0.00056 & 0.00027 \\
\hline 15 & 12-Cr & 10.474 & 0.057 & 0.003 & 0.007 & 0.1564 & 0.0139 & 0.00696 & 0.00203 & 0.00149 \\
\hline 16 & 12-Cr & 11.787 & 0.063 & 0.004 & 0.008 & 0.1813 & 0.01415 & 0.00726 & 0.00203 & 0.00158 \\
\hline 17 & $13^{\mathrm{b}}$ & 1.574 & 3.641 & 0.328 & 0.791 & 0.09003 & 0.08658 & 0.06919 & 0.01467 & 0.01013 \\
\hline 18 & ${13^{b}}^{b}$ & 1.423 & 3.216 & 0.299 & 0.71 & 0.07872 & 0.07304 & 0.05802 & 0.01428 & 0.00964 \\
\hline 19 & 13-Cr & 7.044 & 13.097 & 1.213 & 2.857 & 0.40923 & 0.54832 & 0.31799 & 0.03679 & 0.02299 \\
\hline 20 & 13-Cr & 9.017 & 14.402 & 1.307 & 3.079 & 0.50788 & 0.66979 & 0.34547 & 0.04323 & 0.02496 \\
\hline 21 & $14^{\mathrm{b}}$ & 0.772 & 0.183 & 0.008 & 0.016 & 0.03762 & 0.01038 & 0.00073 & 0.00297 & 0 \\
\hline 22 & $14^{\mathrm{b}}$ & 1.396 & 0.317 & 0.015 & 0.027 & 0.07081 & 0.01999 & 0.00299 & 0.00049 & 0.00033 \\
\hline 23 & 14-Cr & 22.961 & 3.126 & 0.171 & 0.293 & 1.72026 & 0.38775 & 0.10919 & 0.00771 & 0.00387 \\
\hline 24 & 14-Cr & 28.468 & 3.899 & 0.197 & 0.372 & 2.40784 & 0.51208 & 0.15085 & 0.0013 & 0 \\
\hline 25 & $15^{\mathrm{b}}$ & 0.32 & 0.097 & 0.119 & 0.192 & 0.13386 & 0.05863 & 0.08333 & 0.04318 & 0.03795 \\
\hline 26 & $15^{b}$ & 0.308 & 0.094 & 0.115 & 0.186 & 0.12984 & 0.05721 & 0.07998 & 0.03432 & 0.02923 \\
\hline 27 & 15-Cr & 0.054 & 0.165 & 0.057 & 0.099 & 0.07054 & 0.03078 & 0.04199 & 0.01986 & 0.01641 \\
\hline 28 & 15-Cr & 0.049 & 0.148 & 0.052 & 0.088 & 0.06388 & 0.02903 & 0.03893 & 0.01813 & 0.01479 \\
\hline 29 & $9^{b}$ & 4.524 & 3.428 & 0.616 & 1.18 & 0.56303 & 0.63225 & 0.22001 & 0.01681 & 0.00511 \\
\hline 30 & $9^{b}$ & 4.98 & 3.706 & 0.665 & 1.276 & 0.61999 & 0.6923 & 0.23969 & 0.01279 & 0.00539 \\
\hline 31 & 9-Cr & 2.837 & 3.964 & 0.532 & 1.042 & 0.47057 & 0.52712 & 0.18728 & 0.00888 & 0.0039 \\
\hline 32 & 9-Cr & 2.536 & 3.486 & 0.474 & 0.922 & 0.42158 & 0.47207 & 0.16624 & 0.0131 & 0.00344 \\
\hline 33 & $16^{\mathrm{b}}$ & 0.018 & 0.084 & 0.001 & 0.004 & 0.00412 & 0.00023 & 0.00019 & 0 & 0 \\
\hline 34 & $16^{\mathrm{b}}$ & 0.024 & 0.11 & 0.001 & 0.006 & 0.00482 & 0 & 0 & 0 & 0 \\
\hline 35 & 16-Cr & 0.329 & 0.198 & 0.019 & 0.033 & 0.01888 & 0.00417 & 0.00711 & 0.00406 & 0.0019 \\
\hline 36 & 16-Cr & 0.317 & 0.199 & 0.019 & 0.034 & 0.01917 & 0.00369 & 0.00735 & 0.00256 & 0.00209 \\
\hline 37 & $17^{\mathrm{b}}$ & 0.01 & 2.101 & 0.001 & 0.005 & 0.01423 & 0.00082 & 0.00187 & 0 & 0 \\
\hline 38 & $17^{\mathrm{b}}$ & 0.01 & 2.204 & 0.001 & 0.005 & 0.01438 & 0.00108 & 0.0023 & 0.015 & 0.00137 \\
\hline 39 & 17-Cr & 7.38 & 0.00700 & 0.00100 & 0.00400 & 0.08430 & 0.00099 & 0.00194 & 0.00160 & 0.00000 \\
\hline 40 & 17-Cr & 9.406 & 0.00800 & 0.00100 & 0.00600 & 0.11446 & 0.00086 & 0.00177 & 0.00000 & 0.00000 \\
\hline
\end{tabular}

${ }^{\mathrm{a}} \mathrm{C} 10$ - C18: Higher $\alpha$-olefins include decenes, dodecenes, tetradecenes, hexadecenes, and octadecenes. GC retention times in Table S2 on pg. 4

bIn situ catalyst formation with $\mathrm{CrCl}_{3}(\mathrm{THF})_{3}$.

${ }^{c} 0.1 \mu \mathrm{mol}$ of $\mathrm{Cr}$, total volume $=5 \mathrm{~mL}$, solvent $=$ methylcyclohexane, MMAO-3A: $\mathrm{Cr}=1000: 1,45^{\circ} \mathrm{C}, 500$ psi ethylene, 30 -minute reaction time, values are averages of duplicates. 
Table S7. Amount of Products Produced in Milligrams for Chromium Catalysts Evaluated for Ethylene Oligomerization in the High-Throughput Reactor

\begin{tabular}{|c|c|c|c|c|c|c|c|c|c|c|c|c|}
\hline Entry & Compound & $\begin{array}{l}\text { 1-octene } \\
\text { (mg) }\end{array}$ & $\begin{array}{l}\text { 1-hexene } \\
\text { (mg) }\end{array}$ & $\begin{array}{l}\text { Methylcyclo-pentane } \\
(\mathrm{mg})\end{array}$ & $\begin{array}{l}\text { Methylenecyclo-pentane } \\
(\mathrm{mg})\end{array}$ & $\begin{array}{l}\mathrm{C} 10^{\mathrm{b}} \\
(\mathrm{mg})\end{array}$ & $\begin{array}{l}\mathrm{C} 12^{\mathrm{b}} \\
(\mathrm{mg})\end{array}$ & $\begin{array}{l}\mathrm{C} 14^{\mathrm{b}} \\
(\mathrm{mg})\end{array}$ & $\begin{array}{l}\mathrm{C} 16^{\mathrm{b}} \\
(\mathrm{mg})\end{array}$ & $\begin{array}{l}\mathrm{C} 18^{\mathrm{b}} \\
(\mathrm{mg})\end{array}$ & $\begin{array}{c}\text { HDPE } \\
(\mathrm{mg})\end{array}$ & $\begin{array}{l}\text { Total } \\
(\mathrm{mg})\end{array}$ \\
\hline 1 & $2^{\mathrm{b}}$ & 744.0 & 154.9 & 26.0 & 27.8 & 20.98 & 26.66 & 27.56 & 8.84 & 6.31 & 21.0 & 1063.9 \\
\hline 2 & $2^{\mathrm{b}}$ & 898.2 & 208.2 & 31.4 & 33.3 & 26.61 & 38.32 & 37.26 & 9.43 & 6.84 & 25.6 & 1315.1 \\
\hline 3 & 2-Cr & 626.7 & 226.0 & 19.1 & 25.4 & 22.87 & 21.94 & 21.16 & 7.33 & 5.72 & 40.8 & 1016.9 \\
\hline 4 & 2-Cr & 910.3 & 229.4 & 30.8 & 37.1 & 29.12 & 41.09 & 36.45 & 8.18 & 6.30 & 43.6 & 1372.3 \\
\hline 5 & $\mathbf{1 0}^{\mathrm{b}}$ & 98.8 & 29.5 & 7.4 & 24.4 & 2.10 & 1.53 & 1.65 & 1.64 & 0.33 & 14.7 & 181.9 \\
\hline 6 & $10^{b}$ & 113.9 & 33.5 & 7.9 & 28.5 & 2.43 & 1.85 & 1.96 & 0.56 & 0.36 & 18.1 & 209.1 \\
\hline 7 & $10-\mathrm{Cr}$ & 357.8 & 796.8 & 55.4 & 194.9 & 24.40 & 30.55 & 19.28 & 2.00 & 1.09 & 16.3 & 1498.5 \\
\hline 8 & 10-Cr & 463.8 & 882.4 & 63.7 & 217.5 & 29.34 & 36.14 & 20.48 & 2.07 & 1.00 & 22.4 & 1738.9 \\
\hline 9 & $\mathbf{1 1}^{\mathrm{b}}$ & 455.1 & 88.8 & 4.7 & 11.3 & 36.21 & 10.58 & 2.10 & 0.11 & 0.05 & 12.2 & 621.0 \\
\hline 10 & $11^{\mathrm{b}}$ & 565.0 & 101.3 & 5.4 & 12.7 & 42.74 & 12.18 & 2.35 & 0.12 & 0.07 & 15.5 & 757.3 \\
\hline 11 & 11-Cr & 2022.5 & 238.0 & 12.1 & 29.9 & 223.59 & 40.16 & 13.33 & 0.09 & 0.00 & 12.6 & 2592.1 \\
\hline 12 & 11-Cr & 2015.5 & 236.4 & 13.0 & 30.4 & 210.41 & 39.43 & 12.74 & 0.11 & 0.00 & 11.0 & 2568.9 \\
\hline 13 & $\mathbf{1 2}^{\mathrm{b}}$ & 1.6 & 1.9 & 0.1 & 0.2 & 0.10 & 0.01 & 0.01 & 0.02 & 0.00 & 16.3 & 20.1 \\
\hline 14 & $12^{\mathrm{b}}$ & 2.1 & 3.1 & 0.1 & 0.3 & 0.11 & 0.02 & 0.02 & 0.03 & 0.01 & 19.5 & 25.2 \\
\hline 15 & 12-Cr & 523.7 & 2.9 & 0.2 & 0.4 & 7.82 & 0.70 & 0.35 & 0.10 & 0.07 & 10.4 & 546.5 \\
\hline 16 & 12-Cr & 589.4 & 3.2 & 0.2 & 0.4 & 9.07 & 0.71 & 0.36 & 0.10 & 0.08 & 13.4 & 616.8 \\
\hline 17 & $\mathbf{1 3}^{\mathrm{b}}$ & 78.7 & 182.1 & 16.4 & 39.6 & 4.50 & 4.33 & 3.46 & 0.73 & 0.51 & 14.6 & 344.8 \\
\hline 18 & $\mathbf{1 3}^{\mathrm{b}}$ & 71.2 & 160.8 & 15.0 & 35.5 & 3.94 & 3.65 & 2.90 & 0.71 & 0.48 & 18.9 & 313.0 \\
\hline 19 & 13-Cr & 352.2 & 654.9 & 60.7 & 142.9 & 20.46 & 27.42 & 15.90 & 1.84 & 1.15 & 16.0 & 1293.3 \\
\hline 20 & 13-Cr & 450.9 & 720.1 & 65.4 & 154.0 & 25.39 & 33.49 & 17.27 & 2.16 & 1.25 & 13.5 & 1483.3 \\
\hline 21 & $14^{\mathrm{b}}$ & 38.6 & 9.2 & 0.4 & 0.8 & 1.88 & 0.52 & 0.04 & 0.15 & 0.00 & 16.1 & 67.6 \\
\hline 22 & $14^{\mathrm{b}}$ & 69.8 & 15.9 & 0.8 & 1.4 & 3.54 & 1.00 & 0.15 & 0.02 & 0.02 & 16.2 & 108.7 \\
\hline 23 & 14-Cr & 1148.1 & 156.3 & 8.6 & 14.7 & 86.01 & 19.39 & 5.46 & 0.39 & 0.19 & 13.3 & 1452.3 \\
\hline 24 & 14-Cr & 1423.4 & 195.0 & 9.9 & 18.6 & 120.39 & 25.60 & 7.54 & 0.07 & 0.00 & 15.5 & 1815.9 \\
\hline 25 & $15^{\mathrm{b}}$ & 16.0 & 4.9 & 6.0 & 9.6 & 6.69 & 2.93 & 4.17 & 2.16 & 1.90 & 22.5 & 76.7 \\
\hline 26 & $15^{\mathrm{b}}$ & 15.4 & 4.7 & 5.8 & 9.3 & 6.49 & 2.86 & 4.00 & 1.72 & 1.46 & 16.7 & 68.4 \\
\hline 27 & 15-Cr & 2.7 & 8.3 & 2.9 & 5.0 & 3.53 & 1.54 & 2.10 & 0.99 & 0.82 & 22.1 & 49.8 \\
\hline 28 & 15-Cr & 2.5 & 7.4 & 2.6 & 4.4 & 3.19 & 1.45 & 1.95 & 0.91 & 0.74 & 19.3 & 44.4 \\
\hline 29 & $9^{b}$ & 226.2 & 171.4 & 30.8 & 59.0 & 28.15 & 31.61 & 11.00 & 0.84 & 0.26 & 14.0 & 573.3 \\
\hline 30 & $9^{b}$ & 249.0 & 185.3 & 33.3 & 63.8 & 31.00 & 34.62 & 11.98 & 0.64 & 0.27 & 14.0 & 623.9 \\
\hline 31 & 9-Cr & 141.9 & 198.2 & 26.6 & 52.1 & 23.53 & 26.36 & 9.36 & 0.44 & 0.20 & 13.0 & 491.6 \\
\hline 32 & 9-Cr & 126.8 & 174.3 & 23.7 & 46.1 & 21.08 & 23.60 & 8.31 & 0.66 & 0.17 & 11.3 & 436.0 \\
\hline 33 & $16^{b}$ & 0.9 & 4.2 & 0.1 & 0.2 & 0.21 & 0.01 & 0.01 & 0.00 & 0.00 & 18.1 & 23.7 \\
\hline 34 & $16^{\mathrm{b}}$ & 1.2 & 5.5 & 0.1 & 0.3 & 0.24 & 0.00 & 0.00 & 0.00 & 0.00 & 17.9 & 25.2 \\
\hline 35 & 16-Cr & 16.5 & 9.9 & 1.0 & 1.7 & 0.94 & 0.21 & 0.36 & 0.20 & 0.10 & 12.8 & 43.6 \\
\hline 36 & 16-Cr & 15.9 & 10.0 & 1.0 & 1.7 & 0.96 & 0.18 & 0.37 & 0.13 & 0.10 & 20.7 & 50.9 \\
\hline 37 & $17^{\mathrm{b}}$ & 0.5 & 105.1 & 0.1 & 0.3 & 0.71 & 0.04 & 0.09 & 0.00 & 0.00 & 16.4 & 123.1 \\
\hline 38 & $17^{\mathrm{b}}$ & 0.5 & 110.2 & 0.1 & 0.3 & 0.72 & 0.05 & 0.12 & 0.75 & 0.07 & 14.2 & 126.9 \\
\hline 39 & 17-Cr & 369.0 & 0.4 & 0.1 & 0.2 & 4.22 & 0.05 & 0.10 & 0.08 & 0.00 & 11.0 & 385.0 \\
\hline 40 & 17-Cr & 470.3 & 0.4 & 0.1 & 0.3 & 5.72 & 0.04 & 0.09 & 0.00 & 0.00 & 12.5 & 489.4 \\
\hline
\end{tabular}

Yielded Mass via GC Analysis $=(\mathrm{g} / \mathrm{g}$ nonane $) \times 0.050 \mathrm{~g}$ nonane

${ }^{a} \mathrm{C} 10$ - C18: Higher $\alpha$-olefins include decenes, dodecenes, tetradecenes, hexadecenes, and octadecenes. GC retention times in Table S2 on pg. 4

bIn situ catalyst formation with $\mathrm{CrCl}_{3}(\mathrm{THF})_{3}$.

${ }^{c} 0.1 \mu \mathrm{mol}$ of $\mathrm{Cr}$, total volume $=5 \mathrm{~mL}$, solvent $=$ methylcyclohexane, MMAO-3A: $\mathrm{Cr}=1000: 1,45^{\circ} \mathrm{C}, 500$ psi ethylene, 30 -minute reaction time, values are averages of duplicates. 


\section{Batch Reactor Ethylene Oligomerization Data}

Table S8. Chromium Catalysts Evaluated for Ethylene Oligomerization in the 300-mL Parr Batch Reactor

\begin{tabular}{|c|c|c|c|c|}
\hline Entry & Compound & Temperature $\left({ }^{\circ} \mathrm{C}\right)$ & Pressure $(\mathrm{psig})$ & Catalyst loading $(\mu \mathrm{mol})$ \\
\hline 1 & $\mathbf{2 - C r}$ & 70 & 700 & 1.0 \\
\hline 2 & $\mathbf{1 0 - C r}$ & 70 & 700 & 0.5 \\
\hline 3 & $\mathbf{1 1 - C r}$ & 70 & 700 & 0.2 \\
\hline
\end{tabular}

1000 equiv of MMAO-3A, $100 \mathrm{~mL}$ of methylcyclohexane, 30-minute reaction time

GC raw data

\begin{tabular}{|c|c|c|c|c|c|c|c|c|c|c|c|}
\hline Entry & $\begin{array}{c}\text { Compou } \\
\text { nd }\end{array}$ & $\begin{array}{l}\text { Polym } \\
\text { er } \\
\text { yield } \\
\text { (g) }\end{array}$ & $\begin{array}{l}\text { 1-octene } \\
\text { (g/g } \\
\text { nonane) }\end{array}$ & $\begin{array}{c}1- \\
\text { hexene } \\
(\mathrm{g} / \mathrm{g} \\
\text { nonane })\end{array}$ & $\begin{array}{l}\text { Methylcyclopent } \\
\text { ane (g/g nonane) }\end{array}$ & $\begin{array}{l}\text { Methylenecyclopen } \\
\text { tane (g/g nonane) }\end{array}$ & $\begin{array}{c}\mathrm{C} 10 \\
(\mathrm{~g} / \mathrm{g} \\
\text { nonane })\end{array}$ & $\begin{array}{c}\mathrm{C} 12 \\
(\mathrm{~g} / \mathrm{g} \\
\text { nonane })\end{array}$ & $\begin{array}{c}\mathrm{C} 14 \\
(\mathrm{~g} / \mathrm{g} \\
\text { nonane) }\end{array}$ & $\begin{array}{c}\mathrm{C} 16 \\
\text { (g/g } \\
\text { nonane) }\end{array}$ & $\begin{array}{c}\mathrm{C} 18 \\
(\mathrm{~g} / \mathrm{g} \\
\text { nonane) }\end{array}$ \\
\hline 1 & 2-Cr & 0.5554 & 25.7251 & 8.6038 & 78 & 8419 & 5242 & 0.7678 & .5571 & .1236 & 0.0817 \\
\hline 2 & 10-Cr & 0.1196 & 9.0794 & 4.9475 & 0.4975 & 1.3582 & 0.1630 & 0.1925 & 0.1095 & 0.0286 & 0.0198 \\
\hline 3 & 11-Cr & 0.0635 & 2.4841 & 12.0047 & 0.1334 & 0.3401 & 0.3886 & 0.0983 & 0.0303 & 0.0029 & 0.0028 \\
\hline
\end{tabular}

Yielded Mass via GC Analysis $=(\mathrm{g} / \mathrm{g}$ nonane $) \times 1 \mathrm{~mL}$ nonane $\times 0.718 \frac{\mathrm{g}}{\mathrm{mL}}$ (density of nonane $)$

\begin{tabular}{|c|c|c|c|c|c|c|c|c|c|c|c|}
\hline Entry & $\begin{array}{c}\text { Compou } \\
\text { nd }\end{array}$ & $\begin{array}{c}\text { Polym } \\
\text { er } \\
\text { yield } \\
(\mathrm{g})\end{array}$ & $\begin{array}{l}\text { 1-octene } \\
(\mathrm{g})\end{array}$ & $\begin{array}{c}1- \\
\text { hexene } \\
(\mathrm{g})\end{array}$ & $\begin{array}{l}\text { Methylcyclo- } \\
\text { pentane (g) }\end{array}$ & $\begin{array}{l}\text { Methylenecyclo- } \\
\text { pentane (g) }\end{array}$ & $\begin{array}{l}\mathrm{C} 10 \\
(\mathrm{~g})\end{array}$ & $\begin{array}{l}\mathrm{C} 12 \\
(\mathrm{~g})\end{array}$ & $\begin{array}{l}\text { C14 } \\
(\mathrm{g})\end{array}$ & $\begin{array}{l}\text { C16 } \\
(\mathrm{g})\end{array}$ & $\begin{array}{l}\text { C18 } \\
(\mathrm{g})\end{array}$ \\
\hline 1 & 2-Cr & 0.5554 & 18.4706 & 6.1775 & 0.5441 & 0.6045 & 0.3764 & 0.5513 & 0.4000 & 0.0887 & 0.0587 \\
\hline 2 & $10-\mathrm{Cr}$ & 0.1196 & 6.5190 & 3.5523 & 0.3572 & 0.9752 & 0.1170 & 0.1382 & 0.0786 & 0.0205 & 0.0142 \\
\hline 3 & 11-Cr & 0.0635 & 1.7836 & 8.6194 & 0.0958 & 0.2442 & 0.2790 & 0.0706 & 0.0218 & 0.0021 & 0.0020 \\
\hline
\end{tabular}

C10 - C18: Higher $\alpha$-olefins include decenes, dodecenes, tetradecenes, hexadecenes, and octadecenes. GC retention times defined in Table S2 on pg. 4. 
Table S8. Chromium Catalysts Evaluated for Ethylene Oligomerization in the 300-mL Parr Batch Reactor (cont'd)

Activity $(g / g C r h r)=\frac{\mathrm{g} \text { product }}{\left(\left(\frac{\mu \mathrm{mol} \mathrm{Cr}}{1,000,000}\right) \times 52\right)(\mathrm{hr})}$

\begin{tabular}{|c|c|c|c|c|c|c|c|c|c|c|c|}
\hline $\begin{array}{c}\text { Entr } \\
\mathrm{y}\end{array}$ & $\begin{array}{c}\text { Compou } \\
\text { nd }\end{array}$ & $\begin{array}{c}\text { 1-octene } \\
\text { activity } \\
\text { (g/g Cr } \\
\text { hr) }\end{array}$ & $\begin{array}{c}1- \\
\text { hexene } \\
\text { activity } \\
\text { (g/g Cr } \\
\text { hr) }\end{array}$ & $\begin{array}{l}\text { Methylcyclopent } \\
\text { ane activity } \\
\text { (g/g Cr hr) }\end{array}$ & $\begin{array}{c}\text { Methylenecyclopen } \\
\text { tane activity } \\
\text { (g/g Cr hr) }\end{array}$ & $\begin{array}{c}\mathrm{C} 10 \\
\text { activity } \\
\text { (g/g Cr } \\
\text { hr) }\end{array}$ & $\begin{array}{c}\mathrm{C} 12 \\
\text { activity } \\
\text { (g/g Cr } \\
\text { hr) }\end{array}$ & $\begin{array}{c}\text { C14 } \\
\text { activity } \\
\text { (g/g Cr } \\
\text { hr) }\end{array}$ & $\begin{array}{c}\mathrm{C} 16 \\
\text { activity } \\
(\mathrm{g} / \mathrm{g} \mathrm{Cr} \\
\mathrm{hr})\end{array}$ & $\begin{array}{c}\mathrm{C} 18 \\
\text { activity } \\
\text { (g/g Cr } \\
\text { hr) }\end{array}$ & $\begin{array}{c}\text { Polymer } \\
\text { activity } \\
\text { (g/g Cr } \\
\text { hr) }\end{array}$ \\
\hline 1 & 2-Cr & 710,409 & 237,596 & 20,928 & 23,249 & 14,476 & 21,204 & 15,383 & 3,412 & 2,257 & 21,362 \\
\hline 2 & $10-\mathrm{Cr}$ & 501,461 & 273,254 & 27,478 & 75,017 & 9,003 & 10,630 & 6,047 & 1,579 & 1,093 & 9,200 \\
\hline 3 & 11-Cr & 342,991 & $\begin{array}{c}1,657,57 \\
9 \\
\end{array}$ & 18,418 & 46,955 & 53,661 & 13,572 & 4,187 & 396 & 381 & 12,212 \\
\hline
\end{tabular}

Selectivity $(w t \%)=\left(\frac{\text { g product }}{\text { total g product }}\right) \times 100$

\begin{tabular}{|c|c|c|c|c|c|c|c|c|c|c|c|}
\hline $\begin{array}{c}\text { Entr } \\
\mathrm{y}\end{array}$ & $\begin{array}{c}\text { Compou } \\
\text { nd }\end{array}$ & $\begin{array}{c}\text { 1-Octen } \\
\mathrm{e} \\
\text { selectivi } \\
\text { ty } \\
(\mathrm{wt} \%)\end{array}$ & $\begin{array}{c}1- \\
\text { hexene } \\
\text { selectivi } \\
\text { ty } \\
(\mathrm{wt} \%)\end{array}$ & $\begin{array}{l}\text { Methylcyclopent } \\
\text { ane selectivity } \\
(\mathrm{wt} \%)\end{array}$ & $\begin{array}{c}\text { Methylenecyclopen } \\
\text { tane selectivity } \\
(\mathrm{wt} \%)\end{array}$ & $\begin{array}{c}\text { C10 } \\
\text { selectivi } \\
\text { ty } \\
(\mathrm{wt} \%)\end{array}$ & $\begin{array}{c}\text { C12 } \\
\text { selectivi } \\
\text { ty } \\
(\mathrm{wt} \%)\end{array}$ & $\begin{array}{c}\mathrm{C} 14 \\
\text { selectivi } \\
\text { ty } \\
(\mathrm{wt} \%)\end{array}$ & $\begin{array}{c}\text { C16 } \\
\text { selectivi } \\
\text { ty } \\
(\mathrm{wt} \%)\end{array}$ & $\begin{array}{c}\text { C18 } \\
\text { selectivi } \\
\text { ty } \\
(\mathrm{wt} \%)\end{array}$ & $\begin{array}{c}\text { Polymer } \\
\text { selectivi } \\
\text { ty } \\
(\mathrm{wt} \%)\end{array}$ \\
\hline 1 & $2-\mathrm{Cr}$ & 66.4 & 22.2 & 2.0 & 2.2 & 1.35 & 1.98 & 1.44 & 0.32 & 0.21 & 2.00 \\
\hline 2 & 10-Cr & 54.8 & 29.9 & 3.0 & 8.2 & 0.98 & 1.16 & 0.66 & 0.17 & 0.12 & 1.01 \\
\hline 3 & 11-Cr & 16.0 & 77.1 & 0.9 & 2.2 & 2.50 & 0.63 & 0.19 & 0.02 & 0.02 & 0.57 \\
\hline
\end{tabular}

C10 - C18: Higher $\alpha$-olefins include decenes, dodecenes, tetradecenes, hexadecenes, and octadecenes. GC retention times defined in Table S2 on pg. 4. 
Example of Activity and Selectivity Calculations: 10-Cr

Oligomerization Conditions

\begin{tabular}{|c|c|c|c|c|c|c|c|}
\hline Catalyst & $\begin{array}{c}\text { Catalyst } \\
(\mu \mathrm{mol})\end{array}$ & $\begin{array}{c}\text { Temperature } \\
\left({ }^{\circ} \mathrm{C}\right)\end{array}$ & $\begin{array}{c}\text { Pressure } \\
(\mathrm{psi})\end{array}$ & $\begin{array}{c}\text { Run time } \\
(\mathrm{min})\end{array}$ & $\begin{array}{c}\text { Nonane } \\
(\mathrm{mg})\end{array}$ & $\begin{array}{c}\text { MMAO- } \\
\text { 3A:Cr ratio }\end{array}$ & $\begin{array}{c}\text { MMAO- } \\
3 \mathrm{~A} \\
(\mu \mathrm{mol})\end{array}$ \\
\hline $\mathbf{1 0 - C r}$ & 0.01 & 45 & 500 & 30 & 50 & $1000: 1$ & 100 \\
\hline
\end{tabular}

GC raw data

\begin{tabular}{|c|c|c|c|c|}
\hline Catalyst & $\begin{array}{c}\text { 1-Octene } \\
(\mathrm{g} / \mathrm{g} \text { nonane }) \\
(6.9 \mathrm{~min}) *\end{array}$ & $\begin{array}{c}\text { 1-Hexene } \\
(\mathrm{g} / \mathrm{g} \text { nonane }) \\
(2.8 \mathrm{~min})\end{array}$ & $\begin{array}{c}\text { Methylcyclopentane } \\
\text { (g/g nonane }) \\
(3.3 \mathrm{~min})\end{array}$ & $\begin{array}{c}\text { Methylenecyclopentane } \\
\text { (g/g nonane }) \\
(3.6 \mathrm{~min})\end{array}$ \\
\hline $\mathbf{1 0 - C r}$ & 15.9357 & 7.1559 & 1.1078 & 3.8990 \\
\hline
\end{tabular}

\begin{tabular}{|c|c|c|c|c|c|}
\hline Catalyst & $\begin{array}{c}\text { Decenes } \\
(\mathrm{g} / \mathrm{g} \text { nonane }) \\
(10.0-11.0 \mathrm{~min})\end{array}$ & $\begin{array}{c}\text { Dodecenes } \\
(\mathrm{g} / \mathrm{g} \text { nonane }) \\
(11.3-11.8 \mathrm{~min})\end{array}$ & $\begin{array}{c}\text { Tetradecenes } \\
(\mathrm{g} / \mathrm{g} \text { nonane }) \\
(11.8-12.7 \mathrm{~min})\end{array}$ & $\begin{array}{c}\text { Hexadecenes } \\
(\mathrm{g} / \mathrm{g} \text { nonane }) \\
(13.0-13.5 \mathrm{~min})\end{array}$ & $\begin{array}{c}\text { Octadecenes } \\
(\mathrm{g} / \mathrm{g} \text { nonane }) \\
(13.7-14.2 \mathrm{~min})\end{array}$ \\
\hline $\mathbf{1 0 - C r}$ & 0.4880 & 0.61094 & 0.3855 & 0.0399 & 0.0218 \\
\hline
\end{tabular}

$*$ GC retention times

Yielded Mass via GC Analysis = (g/g nonane $) \times 0.050 \mathrm{~g}$ nonane

\begin{tabular}{|c|c|c|c|c|c|}
\hline Catalyst & $\begin{array}{c}1-\text { Octene } \\
(\mathrm{g})\end{array}$ & $\begin{array}{c}\text { 1-Hexene } \\
(\mathrm{g})\end{array}$ & $\begin{array}{c}\text { Methylcyclopentane } \\
(\mathrm{g})\end{array}$ & $\begin{array}{c}\text { Methylenecyclopentane } \\
(\mathrm{g})\end{array}$ & $\begin{array}{c}\text { Polymer* } \\
(\mathrm{g})\end{array}$ \\
\hline $\mathbf{1 0 - C r}$ & 0.7968 & 0.3578 & 0.0554 & 0.1949 & 0.0163 \\
\hline
\end{tabular}

\begin{tabular}{|c|c|c|c|c|c|c|}
\hline Catalyst & $\begin{array}{c}\text { Decenes } \\
(\mathrm{g})\end{array}$ & $\begin{array}{c}\text { Dodecenes } \\
(\mathrm{g})\end{array}$ & $\begin{array}{c}\text { Tetradecenes } \\
(\mathrm{g})\end{array}$ & $\begin{array}{c}\text { Hexadecenes } \\
(\mathrm{g})\end{array}$ & $\begin{array}{c}\text { Octadecenes } \\
(\mathrm{g})\end{array}$ & $\begin{array}{c}\text { Total } \\
(\mathrm{g})\end{array}$ \\
\hline $\mathbf{1 0 - C r}$ & 0.0244 & 0.03055 & 0.01928 & 0.00200 & 0.00109 & $\mathbf{1 . 4 9 8 5}$ \\
\hline
\end{tabular}

*Polymer mass obtained by gravimetric analysis

Activity $(\mathrm{g} / \mathrm{g} \mathrm{Cr} \mathrm{hr})=\frac{\mathrm{g} \text { product }}{\left(\left(\frac{\mu \mathrm{mol} \mathrm{Cr}}{1,000,000}\right) \times 52\right)(\mathrm{hr})}$

\begin{tabular}{|c|c|c|c|c|c|}
\hline Catalyst & $\begin{array}{c}\text { 1-Octene } \\
\text { (g/g Cr hr) }\end{array}$ & $\begin{array}{c}\text { 1-Hexene } \\
\text { (g/g Cr hr) }\end{array}$ & $\begin{array}{c}\text { Methylcyclopentane } \\
\text { (g/g Cr hr) }\end{array}$ & $\begin{array}{c}\text { Methylenecyclopentane } \\
\text { (g/g Cr hr) }\end{array}$ & $\begin{array}{c}\text { Polymer } \\
\text { (g/g Cr } \\
\text { hr })\end{array}$ \\
\hline $\mathbf{1 0 - C r}$ & 306,455 & 137,613 & 21,304 & 74,980 & 6,269 \\
\hline
\end{tabular}

\begin{tabular}{|c|c|c|c|c|c|c|}
\hline Catalyst & $\begin{array}{c}\text { Decenes } \\
(\mathrm{g} / \mathrm{g} \mathrm{Cr} \mathrm{hr})\end{array}$ & $\begin{array}{c}\text { Dodecenes } \\
(\mathrm{g} / \mathrm{g} \mathrm{Cr} \mathrm{hr})\end{array}$ & $\begin{array}{c}\text { Tetradecenes } \\
(\mathrm{g} / \mathrm{g} \mathrm{Cr} \mathrm{hr})\end{array}$ & $\begin{array}{c}\text { Hexadecenes } \\
(\mathrm{g} / \mathrm{g} \mathrm{Cr} \mathrm{hr})\end{array}$ & $\begin{array}{c}\text { Octadecenes } \\
(\mathrm{g} / \mathrm{g} \mathrm{Cr} \mathrm{hr})\end{array}$ & $\begin{array}{c}\text { Total } \\
\text { Activity } \\
\text { (g/g Cr hr })\end{array}$ \\
\hline $\mathbf{1 0 - C r}$ & 9,385 & 11,749 & 7,413 & 768 & 420 & $\mathbf{5 7 6 , 3 5 7}$ \\
\hline
\end{tabular}

Selectivity $(\mathrm{wt} \%)=\left(\frac{\text { g product }}{\text { total g product }}\right) \times 100$

\begin{tabular}{|c|c|c|c|c|c|}
\hline Catalyst & $\begin{array}{c}\text { 1-Octene } \\
(\mathrm{wt} \%)\end{array}$ & $\begin{array}{c}\text { 1-Hexene } \\
(\mathrm{wt} \%)\end{array}$ & $\begin{array}{c}\text { Methylcyclopentane } \\
\text { (wt\%) }\end{array}$ & $\begin{array}{c}\text { Methylenecyclopentane } \\
(\mathrm{wt} \%)\end{array}$ & $\begin{array}{c}\text { Polymer } \\
\text { (wt\%) }\end{array}$ \\
\hline $\mathbf{1 0 - C r}$ & 53.2 & 23.9 & 3.7 & 13.0 & 1.1 \\
\hline
\end{tabular}




\begin{tabular}{|c|c|c|c|c|c|c|}
\hline Catalyst & $\begin{array}{c}\text { Decenes } \\
(\mathrm{wt} \%)\end{array}$ & $\begin{array}{c}\text { Dodecenes } \\
(\mathrm{wt} \%)\end{array}$ & $\begin{array}{c}\text { Tetradecenes } \\
(\mathrm{wt} \%)\end{array}$ & $\begin{array}{c}\text { Hexadecenes } \\
(\mathrm{wt} \%)\end{array}$ & $\begin{array}{c}\text { Octadecenes } \\
(\mathrm{wt} \%)\end{array}$ & $\begin{array}{c}\text { Total } \\
\text { Selectivity } \\
(\mathrm{wt} \%)\end{array}$ \\
\hline $\mathbf{1 0 - C r}$ & 1.6 & 2.0 & 1.3 & 0.1 & 0.1 & 100.0 \\
\hline
\end{tabular}

Catalysts were duplicated in each library. The selectivities and activities obtained from each replicate were averaged together. 


\section{References}

${ }^{1}$ Boelter, S. D.; Davies, D. R. ; Milbrandt, K. A.; Wilson, D. R.; Wiltzius, M.; Rosen, M. S.; Klosin, J. Organometallics, 2020, DOI: 10.1021/acs.organomet.9b00721.

2 M. J. Frisch, G. W. Trucks, H. B. Schlegel, G. E. Scuseria, M. A. Robb, J. R. Cheeseman, G. Scalmani, V. Barone, B. Mennucci, G. A. Petersson, H. Nakatsuji, M. Caricato, X. Li, H. P. Hratchian, A. F. Izmaylov, J. Bloino, G. Zheng, J. L. Sonnenberg, M. Hada, M. Ehara, K. Toyota, R. Fukuda, J. Hasegawa, M. Ishida, T. Nakajima, Y. Honda, O. Kitao, H. Nakai, T. Vreven, J. A. Montgomery, Jr., J. E. Peralta, F. Ogliaro, M. Bearpark, J. J. Heyd, E. Brothers, K. N. Kudin, V. N. Staroverov, T. Keith, R. Kobayashi, J. Normand, K. Raghavachari, A. Rendell, J. C. Burant, S. S. Iyengar, J. Tomasi, M. Cossi, N. Rega, J. M. Millam, M. Klene, J. E. Knox, J. B. Cross, V. Bakken, C. Adamo, J. Jaramillo, R. Gomperts, R. E. Stratmann, O. Yazyev, A. J. Austin, R. Cammi, C. Pomelli, J. W. Ochterski, R. L. Martin, K. Morokuma, V. G. Zakrzewski, G. A. Voth, P. Salvador, J. J. Dannenberg, S. Dapprich, A. D. Daniels, O. Farkas, J. B. Foresman, J. V. Ortiz, J. Cioslowski, and D. J. Fox, Gaussian, Inc., Wallingford CT, 2013.

${ }^{3}$ Hamprecht, F. A.; Cohen, A.; Tozer, D. J.; Handy, N. C. J. Chem. Phys., 1998, 109, 6264.

${ }^{4}$ Jiang, W.; Laury, M. L.; Powell, M.; Wilson, A. J. Chem. Theor. Comput. 2012, 8, 4102.

${ }^{5}$ Neese, F. The ORCA program system, Wiley Interdiscip. Rev.: Comput. Mol. Sci., 2012, 2, 73-78.

${ }^{6}$ Tao, J.; Perdew, J. P.; Staroverov, V. N.; Scuseria, G. E. Phys. Rev. Lett. 2003, 91, 146401.

7 a. Grimme, S.; Ehrlich, S.; Goerigk, L. J. Comput. Chem., 2011, 32, 1456-1465. b. Grimme, S.; Antony, J.; Ehrlich S.; Krieg, H. J. Chem. Phys., 2010, 132, 154104.

${ }^{8}$ Weigend, F.; Ahlrichs, R. Phys. Chem. Chem. Phys. 2005, 7, 3297. 